VILNIUS GEDIMINAS TECHNICAL UNIVERSITY

Kamilè TAUJANSKAITÉ

\title{
A SYSTEM FOR FORMALIZED CONTROL OF PERSONAL CONSUMPTION EXPENDITURE
}

DOCTORAL DISSERTATION

SOCIAL SCIENCES,

ECONOMICS (04S)

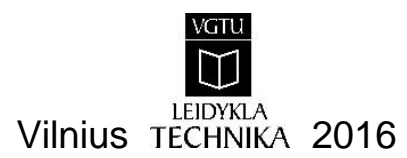


Doctoral dissertation was prepared at Vilnius Gediminas Technical University in 2011-2016.

\section{Supervisor}

Prof. Dr Habil. Aleksandras Vytautas RUTKAUSKAS (Vilnius Gediminas Technical University, Economics - 04S).

The Dissertation Defense Council of Scientific Field of Economics of Vilnius Gediminas Technical University:

\section{Chairman}

Prof. Dr Jelena STANKEVIČIENE (Vilnius Gediminas Technical University, Economics - 04S).

\section{Members:}

Prof. Dr Habil. Romualdas GINEVIČIUS (Vilnius Gediminas Technical University, Economics - 04S),

Prof. Dr Natalja LACE (Riga Technical University, Economics - 04S),

Assoc. Prof. Dr Algita MIEČINSKIENE (Vilnius Gediminas Technical University, Economics - 04S),

Prof. Dr Bronius NEVERAUSKAS (Kaunas University of Technology, Management - 03S).

The dissertation will be defended at the public meeting of the Dissertation Defense Council of Economics in the Senate Hall of Vilnius Gediminas Technical University at 2 p. m. on 20 June 2016.

Address: Sauletekio al. 11, LT-10223 Vilnius, Lithuania. Tel.: +370 5274 4956; fax +370 5270 0112; e-mail: doktor@vgtu.lt

A notification on the intended defending of the dissertation was send on 19 May 2016.

A copy of the doctoral dissertation is available for review at VGTU repository http://dspace.vgtu.lt and at the Library of Vilnius Gediminas Technical University (Saulètekio al. 14, LT-10223 Vilnius, Lithuania).

VGTU leidyklos TECHNIKA 2369-M mokslo literatūros knyga

ISBN 978-609-457-931-8

(C) VGTU leidykla TECHNIKA, 2016

(C) Kamilè Taujanskaitè, 2016

kamile.taujanskaite@vgtu.lt 
VILNIAUS GEDIMINO TECHNIKOS UNIVERSITETAS

Kamilè TAUJANSKAITÉ

\section{ASMENINIO VARTOJIMO PINIGINIŲ SRAUTU FORMALIZUOTO VALDYMO SISTEMA}

DAKTARO DISERTACIJA

SOCIALINIAI MOKSLAI, EKONOMIKA (04S)

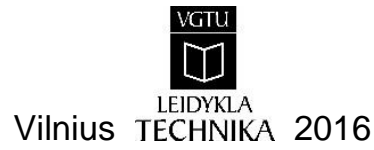


Disertacija rengta 2011-2016 metais Vilniaus Gedimino technikos universitete.

\section{Vadovas}

prof. habil. dr. Aleksandras Vytautas RUTKAUSKAS (Vilniaus Gedimino technikos universitetas, ekonomika-04S).

Vilniaus Gedimino technikos universiteto Ekonomikos mokslo krypties disertacijos gynimo taryba:

\section{Pirmininkas}

prof. dr. Jelena STANKEVIČIENĖ (Vilniaus Gedimino technikos universitetas, ekonomika-04S).

\section{Nariai:}

prof. habil. dr. Romualdas GINEVIČIUS (Vilniaus Gedimino technikos universitetas, ekonomika-04S),

prof. dr. Natalja LACE (Rygos technikos universitetas, ekonomika - 04S), doc. dr. Algita MIEČINSKIENE (Vilniaus Gedimino technikos universitetas, ekonomika-04S),

prof. dr. Bronius NEVERAUSKAS (Kauno technologijos universitetas, vadyba - 03S).

Disertacija bus ginama viešame Ekonomikos mokslo krypties disertacijos gynimo tarybos posèdyje 2016 m. birželio 20 d. 14 val. Vilniaus Gedimino technikos universiteto senato posėdžių salèje.

Adresas: Saulètekio al. 11, LT-10223 Vilnius, Lietuva.

Tel.: (8 5) 274 4956; faksas (8 5) 270 0112; el. paštas doktor@vgtu.lt

Pranešimai apie numatomą ginti disertaciją išsiusti 2016 m. gegužès 19 d.

Disertaciją galima peržiūrèti VGTU talpykloje http://dspace.vgtu.lt ir Vilniaus Gedimino technikos universiteto bibliotekoje (Sauletekio al. 14, LT-10223 Vilnius, Lietuva). 


\section{Abstract}

Personal consumption expenditure (PCE) makes approximately $2 / 3$ of the gross domestic product in Lithuania; therefore, efficiency of its control is of high importance for the country's economy. Control of a household's financial resources in general and especially the part intended for financing consumption is a complicated task because of the complex interrelations of decisions to be made with numerous factors of economic, social and cultural origin affecting them. Besides, they strongly depend on the personality of the consumer and his or her ability to harmonise needs with disposable resources. From the mathematical point of view, the allocation of resources to finance purchasing and the related decision-making are identical to multi-objective and multi-attribute optimisation tasks, which have to be performed in the household every time an elementary purchase is being planned. It is therefore important to perform the related decision-making based on objective criteria, free from the influence of the above-mentioned subjective factors. Even the latest resource management methods and tools available to households offer very limited possibilities in this regard; therefore, this study aims to contribute to the further development of them.

The aim of this study is the development and theoretical justification of a formalized, quantitative criteria based system for the control of personal consumption expenditure on both, the elementary purchases and the aggregate countrywide monetary-flow levels, by employing a modified informal cooperation between households and commercial banks. Five objectives have been defined for the achievement of this aim.

Methods used in this study comprise comparative, logical, systemic, and critical analysis methods; a synthesis of multidisciplinary approaches; a questionnaire-based survey; an expert evaluation; and elements from vector, matrix algebra, and differential mathematics.

The thesis is composed of an Introduction, three chapters presenting findings of the research, Conclusions, a Reference list and the author's publications. The problem in the study is analysed from the household and retail banking standpoints with a focus on consumption-related monetary flows at both the household and the aggregate countrywide levels. Research findings target both levels through: a) the developed principles of value decomposition enabling a quantitative evaluation of value components of purchased goods and constituting the base for methods and tools intended for planning and control of resources on the elementary purchases' level; b) the general guidance system of consumption expenditure employing the above-mentioned principles and a specific economic and psychological education program of bank clients, seeking higher efficiency of resource management on both levels thus reflecting the common interests of households and retail banks; and c) the demonstration of payback potential encouraging the banks to invest into development of such a system and to expand informal cooperation with households.

Findings of the research were published in seven papers and presented at seven scientific conferences, of which six were international. 


\section{Reziumè}

Namų ūkių (NŪ), arba asmeninio vartojimo išlaidų, suminiai finansiniai srautai sudaro apie 2/3 Lietuvos bendrojo vidaus produkto (BVP), todèl jų valdymo efektyvumas svarbus šalies ekonominei sistemai. Namų ūkių finansinių išteklių, ypač susijusių su vartojimu, valdymas yra sudètingas dèl sąsajų su daugeliu ekonominių, socialinių, kultūrinių veiksnių, be to, sprendimai priklauso nuo vartotojo asmeninių savybiu ir gebejjimo derinti poreikius su disponuojamais finansiniais ištekliais. Vertinant matematiniu požiūriu, finansiniu ištekliu skyrimas elementariam pirkiniui ịsigyti yra tapatus daugiatikslio ir daugiakriterio optimizavimo uždaviniui, kurị namų ūkis privalo spręsti kiekvieno pirkinio atveju. Tokiomis aplinkybėmis svarbu, kad visi šie sprendimai remtųsi objektyviais kriterijais ir nepriklausytų nuo subjektyvaus jau minètų veiksniu poveikio, tačiau netgi naujausi namų ūkiams skirti šiu išteklių valdymo metodai bei priemonès šia prasme suteikia labai ribotas galimybes. Darbe atliktais tyrimais siekiama plètoti šias galimybes, suteikiant namų ūkiams specifinių žinių ir priemonių, leidžiančių geriau valdyti finansinius išteklius, o komerciniams bankams numatyti perspektyvias plètros ir investavimo strategijas.

Darbo tikslas - modifikuoto namų ūkių ir komercinių bankų bendradarbiavimo pagrindu suformuoti bei teoriškai pagristi asmeninio vartojimo išlaidų formalizuoto valdymo sistemą, grindžiamą kiekybiniais valdymo kriterijais ir aprépiančią tiek elementariuju pirkinių, tiek ir visuminio vartojimo šalies mastu lygius. Tikslui pasiekti iškelti penki uždaviniai.

Tyrimai atlikti naudojant lyginamosios, loginès, sisteminès, apibendrinimo, kritinès analizès metodus, tarpdisciplininių metodų sintezę, anketinę apklausą, ekspertinę analizę, vektoriu bei matricu algebros ir diferencinio skaičiavimo elementus, matematinès statistikos analizès ir matematinio modeliavimo metodus.

Disertaciją sudaro įvadas, trys skyriai, bendrosios išvados, naudotos literatūros ir autoriaus publikacijų sąrašai. Darbe su vartojimu susiję piniginiai srautai ir jų valdymo problemos nagrinėjamos atskiro NŪ ir suminiu šalies mastu piniginių srautu lygiu bei vertinamos tiek NŪ, tiek komerciniu bankų interesų požiūriu. Tyrimai ir gauti rezultatai orientuoti ị šių srautų valdymo efektyvumo gerinimą abiem nagrinèjamais lygiais: a) prekių ir paslaugų vertès dekompozicijos principai, leidžiantys vertès komponentėms suteikti kiekybinius įverčius, bei siūlomi jų praktinio pritaikymo būdai ir atitinkamos taikomosios programos yra skirti NŪ vartojimo išlaidoms planuoti ir valdyti elementariuju pirkinių lygiu; b) šių principų bei banko klientų ekonominio-finansinio ir psichologinio švietimo pagrindu sukurtos poveikio vartojimo piniginiams srautams formavimo sistema paskirtis yra didinti šių srautų valdymo efektyvumą abiem nagrinejjamais lygiais; c) pasiūlyta sistemos ekonominio atsiperkamumo ìvertinimo metodika ir gauti tyrimo rezultatai skatina komercinius bankus investuoti ị jos kūrimą bei plètoti neformalų bendradarbiavimą su namų ūkiais.

Disertacijos tema paskelbti 7 moksliniai straipsniai ir perskaityti 7 pranešimai mokslinèse konferencijose, iš kurių 6 tarptautinès. 
Notations

\section{Concepts and terms}

Flow-of-funds is a set of accounts that is used to follow the flow of money within various sectors of an economy (Investopedia 2016). Specifically, in this study it used to express monetary flow of personal consumption expenditure.

Goods and services market is an economic market where products (goods and services) circulate between households, business and government sectors. Usually it is called a product or commodities market (Mankiw 2011).

Household is: a) one or more persons that live together and have common budget (Vitunskienè 1997); b) a group of people, often a family, who live together in a house or flat (Cambridge Dictionaries 2016); c) it is the group of persons living in the same dwelling, feeding together and also having common budget, but not necessarily related as family members (Business Dictionary 2016). The household is also considered a person living alone. The term 'household' is often the lowest analyzed unit of economists and statisticians (Vainienè 2016).

Household (final) consumption expenditure (formerly private consumption) or personal consumption expenditure is the market value of all goods and services, including durable products (such as cars, washing mashines, home computers) purchased by households. It excludes purchases of dwellings, but includes imputed rent for owneroccupied dwellings. It also includes payments and fees to government to obtain permits and license (World Bank 2016). Personal consumption expenditure (-s) is the primary measure of consumer spending on goods and services. The personal consumption expenditure measure is the component statistic for consumption in gross domestic product (Bureau of Economic Analysis 2016). 
Non-performing loans or bad loans include depreciated loans and overdue more than 60 days (but non-impaired loans), compared to the loan portfolio on a gross basis (Bank of Lithuania 2014).

Non-performing loans ratio is an amount of non-performing loans over total loans, expressed as a percentage (Financial Times 2016).

Monetary financial institution is an institution where households can borrow, like local commercial banks, branches of foreign banks operating in the country, credit unions and other financial institutions. All of them are considered by the Bank of Lithuania (LB) as being Monetary Financial Institutions (MFI) (Bank of Lithuania 2015). According to the European Central Bank (2006), monetary financial institutions are central banks, resident credit institutions and other resident financial institutions whose business is to receive deposits and/or close substitutes for deposits from entities other than MFIs and, for their own account (at least in economic terms), to grant credits and/or make investments in securities. Money market funds are also classified as MFIs. Central Banks are not taken into account in this dissertation.

Retail banking generally refers to the provision of products and services that banks provide to personal customers and small/medium-sized enterprises (SMEs) through a variety of channels, including branches, Internet and mobile technology. Banks typically organise their retail banking activities either by the type of customer served (e.g. personal versus business), products offered (e.g. mortgages, credit cards, insurance, etc.) or size (e.g. small versus large businesses). The main functions of retail banks $\langle\ldots\rangle$ include accepting deposits, making loans, and providing payment services. Retail banking includes personal current accounts, SMEs banking services, also other products such as residential mortgages, personal loans and insurance (Competition and Markets Authority 2015). In this dissertation, SME's financial operations are not taken into account.

Systemic or system-wide approach: affecting or relating to a group or system (such as body, economy or market) as a whole, instead of its individual members or parts (Business Dictionary 2016).

\section{Abbreviations}

$\mathrm{CB}$ - commercial bank (-s)

EU - European Union

FOF - flow-of-funds

GDP - gross domestic product

$\mathrm{HH}$ - household (-s)

iALM - individual's asset-liability management

MFI - monetary financial institution (-s)

NPL - non-performing loan (-s)

PCE - personal consumption expenditure

viii 


\section{Contents}

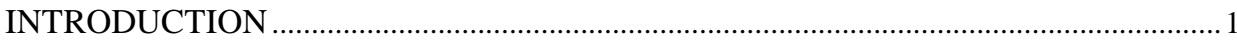

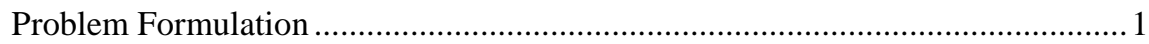

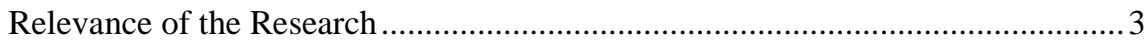

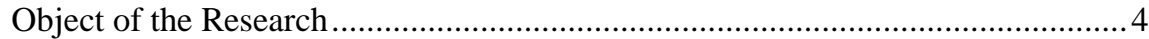

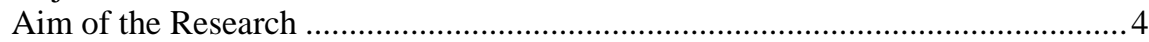

Objectives of the Research .................................................................................. 4

Research Methodology ……………...............................................................

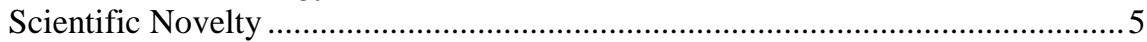

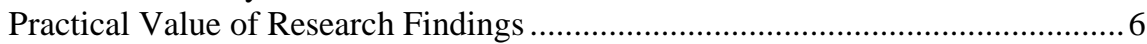

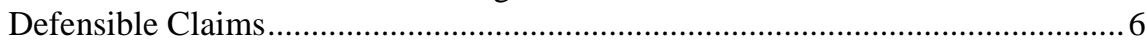

Approval of Research Findings .....................................................................

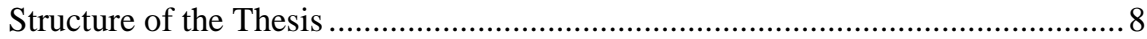

1. HOUSEHOLD MONETARY FLOWS IN FINANCIAL AND PRODUCT MARKETS: MANAGEMENT PROBLEMS FROM THE STANDPOINT OF HOUSEHOLDS AND RETAIL BANKS .....................................................................

1.1. Comparative Analysis of Household Monetary Flows in Product and Retail Banking Markets .............................................................................................. 10

1.2. Research on the Finance Management State in Households under a Changing Macroeconomic Environment ............................................................................ 14

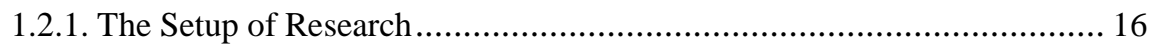


1.2.2. General Information about Respondents........................................... 16

1.2.3. State of Household Budget Management: Efficiency and Trends under Effect of Financial Crisis ............................................................... 17

1.3. Management Problems of Household Expenditure and their Causes ...................2 24

1.3.1. Related Theoretical Concepts............................................................. 24

1.3.2. Role of Consumer Behavior in Household Financial Decisions .............. 32

1.3.2.1. Patterns and Types of Consumer Behaviour and Decision-Making Motivational Mechanisms ............................................................ 32

1.3.2.2. Rationality Problem in Consumer Behaviour................................. 38

1.4. Conclusions of Chapter 1 and Formulating Tasks for the Dissertation ................40

2. FORMALIZED APPROACH TO CONSUMPTION EXPENDITURE MANAGEMENT OF HOUSEHOLDS: PRINCIPLES AND PRACTICAL

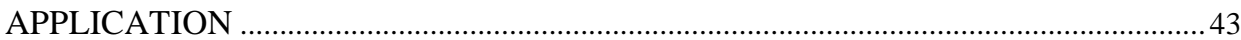

2.1. Analysis of Models Used for Household Financial Flows Management ............. 44

2.2. Integrated Economic-Psychological Approach to the Management of

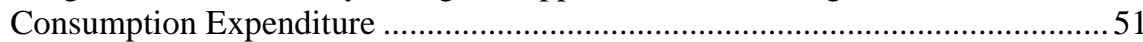

2.3. Value Decomposition. Theortical Justification....................................................54

2.4. Consumption Decision-Making Process and the Use of Value

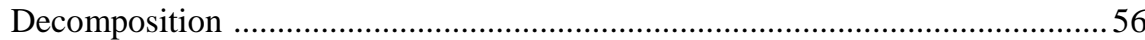

2.5. Practical Application of Value Decomposition for Control of Consumption Expenditure

2.5.1. Value Decomposition as an Integral Part of the Budget Management Process

2.5.2. Advantages of Using Value Decomposition for Expenditure Management on Elementary Purchases and the Aggregate Consumption Level ........... 61

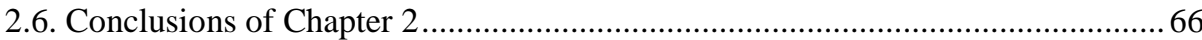

3. MODELLING OF A SYSTEM FOR CONSUMPTION-RELATED MONETARY FLOW GUIDANCE BASED ON MODIFIED COOPERATION BETWEEN HOUSEHOLDS AND RETAIL BANKS ......................................................................... 69

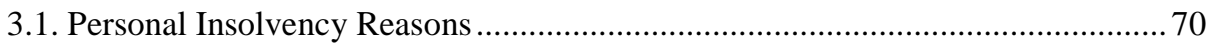

3.1.1. Theoretical Aspects of Insolvency Interpretation ................................. 70

3.1.2. Classification of Insolvency Causes................................................... 72

3.2. Effect of Direct and Indirect Factors on Borrower Performance of

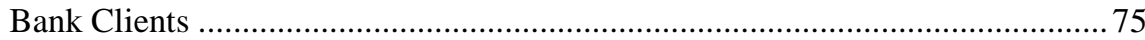

3.2.1. The Setup of Expert Evaluation Survey .............................................. 76

3.2.2. Quantitative Evaluation of Factors Determining the Level of NonPerforming Loans in Retail Banks ..................................................... 80

3.3. Modelling of a System to Guide the Aggregate Monetary Flows Originating from Consumption Expenditure .85

3.3.1. Pay-Back Potential from Investment into Financial and Consumer Awareness Raising of Bank Clients

3.3.2. Current Setup of Collaboration between Retail Banks and Households and Existing Shortcomings 
3.3.3. A System for Guidance of Consumption-Related Monetary Flows based on Modified Collaboration between Households and Retail Banks

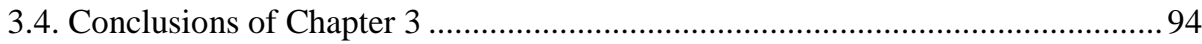

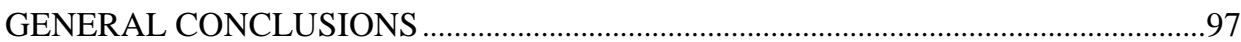

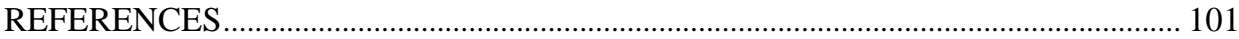

LIST OF SCIENTIFIC PUBLICATIONS BY THE AUTHOR ON THE TOPIC OF THE DISSERTATION ........................................................................................... 115

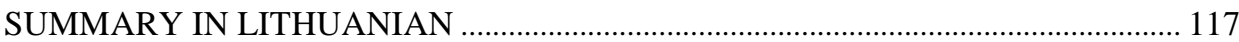

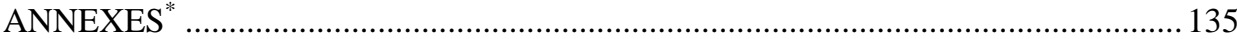

Annex A. Consumption Decision Making Tree.................................................... 137

Annex B. Models for Individual's Asset-Liability Management ............................. 138

Annex C. Algorithms for Practical Use ................................................................ 139

Annex D. Model of a System for Formalized Control of Personal Consumption

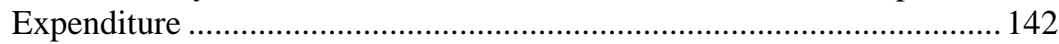

Annex E. Education Program for Bank Clients ..................................................... 143

Annex F. Households' Financial Management Questionnaire_Investigation I ....... 145

Annex G. Households' Financial Management Questionnaire_Investigation II ..... 147

Annex H. Expert Evaluation Questionnaire_Round I.............................................. 149

Annex I. Expert Evaluation Questionnaire_Round II ........................................... 150

Annex J. The Co-Authors' Agreements to Provide Published Material in the

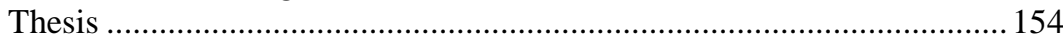

Annex K. Copies of Scientific Publications by the Author on the Topic of the Dissertation

\footnotetext{
* The annexes are supplied in the enclosed compact disc.
} 



\section{Introduction}

\section{Problem Formulation}

Personal consumption expenditure (PCE) accounts for approximately $2 / 3$ of Lithuania's gross domestic product (GDP). A similar share is typical not only for Lithuania but for many other countries around the world. For this only reason, the consumption-related monetary flows produced by households are so important for the economic system of every country. It is the primary engine that drives future economic growth and determines business conditions for virtually any economic entity, regardless of what segment it operates in: manufacturing, services, retail banking or other.

A number of parameters characterising the consumption expenditure is decisive for the economy. While aggregate volume is the main factor to determine the macroeconomic indicators of the market (e.g. the supply-demand balance), the parameters characterising the state and efficiency of its management on the household level, instead, determine the budgetary performance of every household and the performance of financial institutions and commercial banks, which cooperate with them. Therefore, the parameters characterising management efficiency on the household level are as important as the volume. Up to $40 \%$ of Lithuanian households are unable to maintain control of their budgets (the Bank 
of Lithuania 2015), which indicates serious resource management problems specifically at this level. Poor borrower performance of households is another outcome of inefficient resource management in households. The non-performing loan (NPL) level of individuals in commercial banks of Lithuania in 2015 amounted to 5.5\% (the Bank of Lithuania 2016). Although this level was significantly lower than the highest rate of over $20 \%$ reached in 2010, it still remained several times higher than the pre-crisis level of $1-2 \%$ in 2007-2008. This condition of the loan portfolios resulted in a significant loss for commercial banks, which afterwards took five years for them to recover fully.

Similar problems are very important not only for Lithuania but for the economies and banking systems of other countries as well. In 2015, the NPL level in Italy was $17.3 \%$, in Ireland $18.8 \%$, in Greece $34.4 \%$ and even $44.8 \%$ in Cyprus (the World Bank 2016). The value of the non-performing loan portfolio in Italy made 200 billion EUR in 2015, while the total NPL value in the European Union (EU) is estimated to be close to 1 trillion EUR, or about 7\% of its aggregate GDP.

Some studies, including those performed by the Bank of Lithuania (2014) and the commercial banks (Swedbank Personal Finance Institute 2010) show that Lithuanian households lack economic knowledge and financial management skills. Such conditions further increase their financial vulnerability.

According to the Bank of Lithuania (2015), even 88\% of Lithuanian population indicate that they make financial decisions based on their own experience, the opinion of people they know or trust, or information collected from media, including TV and Internet. The relevance and trustworthiness of such information and the motivation of financial decisions based on them are questionable; therefore, it is not surprising that so many households face financial and budget management problems. Management efficiency could improve if decisions made by households were based only on objective and quantifiable criteria. Besides, the application of special formalized decision-making procedures eliminating or at least limiting the interference of such kind of motives, could be beneficial too.

The mentioned problems, that both households and commercial banks face, are obviously caused by the same or similar reasons, making them natural partners in fighting not only the consequences but first of all their root causes.

The analysis of reasons causing these consequences and defining the appropriate ways for their control would certainly help households to improve their budgetary performance as well as the quality of loans issued to them by commercial banks. 


\section{Relevance of the Research}

Researchers from the beginning of the 18th century have investigated various aspects of finance management in households; nevertheless, a number of questions still remain without due answer, especially those related to the control of personal consumption expenditures in a dynamic and permanently changing economic and business environment. The majority of related research studies were performed based on a macroeconomic approach (Smith 1776 [1981]; Keynes 1936, Kuznets 1951, etc.), having in mind the influence of household financial flows on major processes in markets, e.g. balance between supply and demand, economic cycles, etc. This approach mainly focuses on consumption, which becomes a determining factor in describing the condition of a country's economy. The more active the consumption is, the better the conditions are for economic growth and vice versa. Formally, an ideal consumer from this point of view is the one who spends all or almost all resources for current needs without paying attention to saving. The paradox is that the list of ideal consumers in this case would include even those addicted to drugs, gambling, shopping, etc.; therefore, this approach has certain limits.

An alternative or microeconomic approach, on the contrary, analyses the processes from the standpoint of households or individuals and focuses on the utility of consumed goods. The volume of the latter research is relatively limited and incomparable with the macroeconomic and has been mainly conducted up until or around the mid of 20th century (Bernoulli 1738; Kyrk 1923; Becker 1960 , etc.). It does not take into account the latest trends in consumer markets characterised by the increasing influence of irrationality on consumer behavior. The lack of related knowledge has negative effect on households themselves, retail banks, and the public sector; therefore, the in-depth research from the microeconomics perspective is becoming more and more important. The current situation in consumer markets is predetermined by the imbalance between enormous efforts and resources used by sellers to boost sales, on one side, and the limited resources to adequately support the consumers on the other. Most advanced selling technologies, which employ the latest knowledge from economics, psychology and use modern communication tools, strongly affect consumer behaviour. As a result, the financial resources of households in many cases are being exhausted for needs, which have limited utility and create budgetary problems in households and non-performing loan problems in commercial banks.

Neoclassical economic theories that treat consumers as rational (Zinkhman 1992; Ansari 2000), having clear preferences, acting under budget constraints and called a common homo economicus name, cannot explain why so many households having sufficient income face budget deficit problems. Modern con- 
sumer behaviour theories, on the other hand, argue the credibility of these assumptions and emphasize the role of psychological motives, which contradict the concept of homo economicus. They analyse the logic of related decisionmaking, but they do not offer ways of controlling it. Missing answers on the role of income level and the pattern of consumer behaviour on budgetary and borrower performance of households, decision-making efficiency on the elementary purchases level and the possibilities of positively modifying the personal consumption expenditure and the related aggregate monetary flows have led to the choice of research object in this study.

\section{Object of the Research}

This study focuses on the problematic issues in the personal consumption-related flow-of-funds control from the standpoint of households and commercial banks.

\section{Aim of the Research}

The aim of the study is the development of a system for formalized control of personal consumption expenditure on both the elementary purchase and the aggregate monetary-flow levels, based on modified informal cooperation between households and commercial banks.

\section{Objectives of the Research}

The following objectives have been defined for the achievement of the aim of the research:

1. Compare household-related monetary flows in product and retail banking markets and identify their management problems from the standpoint of households and commercial banks.

2. Perform critical analysis of theoretical concepts and practical tools related to the management of monetary flows intended for personal consumption, identify shortcomings and ways for improvement.

3. Develop a formalized, quantitative criteria-based approach to the management of the household consumption expenditure, applicable to elementary purchases. 
4. Investigate and quantitatively evaluate the influence of consumption and financial behaviour on borrower performance of bank clients.

5. Develop a system, involving households and commercial banks, for guidance of personal consumption expenditure, based on formalized decision-making procedures, and a method for the quantitative evaluation of its economic efficiency.

\section{Research Methodology}

A literature analysis was performed by using comparative, logical, and systemic analysis; synthesis; generalization; and critical analysis methods.

Information on the methods, models and tools used to control financial resources of households was analysed by employing comparative, logical and critical analysis methods.

Analysis of monetary flows in product and retail banking markets was based on statistical data processing and logical analysis.

Research of value decomposition is based on the synthesis of two theories: economics and psychology (as referred to in the Maslow hierarchy of needs theory), vector and matrix algebra tools.

Financial behaviour of households and financial awareness research were performed by using sociology methods, questionnaires and comparative analysis.

The expert evaluation (Delphi) method was used for research of reasons causing non-performing loans in retail banking.

Development of a system to guide aggregate monetary flows of personal expenditure was based on the dynamics of statistical data from retail banking, while its expected economic efficiency was analysed by using mathematical analysis and differential mathematics methods.

\section{Scientific Novelty}

Scientific novelty is determined by:

1. The context applied for the research of consumption related flow-offunds, budgetary and borrower performance of households, from the standpoint of households and commercial banks, has not been explored in the literature so far.

2. Value decomposition principles of goods and services, developed by applying synthesis of Maslow's hierarchy of needs and the economics 
theory approaches, enabling quantitative evaluation of their value components, and match with the specific consumer's needs.

3. Formalized approach to the management of personal consumption expenditure, enabling allocation of funds for every elementary purchase in a way which is harmonized with disposable resources, thus avoiding influence of subjective psychological factors on desicion-making.

4. Analysis and classification of direct and indirect factors affecting personal insolvency and a quantitative evaluation of their impact on the level of non-performing loans in retail banks.

5. A system for the guidance of aggregate monetary flows of households, using as a base a modified informal cooperation between households and commercial banks; and a method for evaluation of payback of investment into its development.

\section{Practical Value of Research Findings}

The following findings are of practical value:

1. The principles of formalized personal consumption expenditure control can be used by households for budget planning and allocation of financial resources on elementary purchase level in a way that is free from the influence of subjective factors of psychological character.

2. Software developed by using these principles can be used by households for more efficient budget planning and spending control.

3. A system for the guidance of aggregate monetary flows of households can be beneficial for retail banks through improved borrower performance of individual clients and increased turnover in retail banking because of more efficient financial resource management in households.

\section{Defensible Claims}

1. As product and retail banking markets share the same financial flows originating from households, commercial banks should identify themselves as players competing for them in both markets and adjust their strategies accordingly. Retail banks in Lithuania earn only 1- 
$2 \%$ from the aggregate households consumption expenditure, which is three to five times lower than in countries with the most advanced economies; therefore, retail banks should employ methods and resources adequate to those, used by sellers of goods and nonfinancial services in order to shape the flow of financial resources for the benefit of households and banks.

2. The efficiency of financial resource management in households on the elementary purchase level can be improved by implementing formalized control procedures, limiting the influence of subjective factors of psychological origin on decision-making related to the allocation of resources for consumption.

3. Management efficiency on the aggregate monetary flow level can be improved by implementing a specific guidance system, built-up on a platform representing the modified informal cooperation between households and commercial banks in order to affect indirectly the control of the above mentioned flows through specific education of bank clients in the finance management, economics and psychology, helping raise their consumer awareness.

4. The guidance system is drafted as a profit generating tool. Extra resources used by commercial banks for its financing are expected to pay off through reduced non-performing loan loss.

\section{Approval of Research Findings}

Seven research articles have been published based on this $\mathrm{PhD}$ thesis. One article is published in the ISI Web of Science scientific journal (Taujanskaite et al. 2015); one in ISI Proceedings (Taujanskaite, Milčius 2012), two in peerreviewed international scientific journals (Jurevičienè et al. 2016; Taujanskaité, Milčius 2014), one in a peer-reviewed Lithuanian scientific journal (Taujanskaitè, Jurevičienè 2010) and two in the peer-reviewed materials of international conferences (Taujanskaite, Milčius 2015, Taujanskaitè 2011).

The author has made presentations at seven scientific conferences:

- The $4^{\text {th }}$ International Scientific Conference Contemporary Issues in Business, Management and Education 2015, 12-13 November 2015, Vilnius Gediminas Technical University, Vilnius, Lithuania.

- The $1^{\text {st }}$ International Scientific Conference on Business Management, 14 July 2015, Unversitat Politechnika de Valencia, Valencia, Spain. 
- The $15^{\text {th }}$ International Scientific Conference Perspectives of Business and Entrepreneurship Development, 28-29 May 2015, Brno University of Technology, Brno, Czech Republic.

- The $2^{\text {nd }}$ International Scientific Conference Contemporary Issues in Business, Management and Education 2013, 14-15 November 2013, Vilnius Gediminas Technical University, Vilnius, Lithuania.

- The $7^{\text {th }}$ International Scientific Conference Business and Management 2012, 10-11 May 2012, Vilnius Gediminas Technical University, Vilnius, Lithuania.

- The $1^{\text {st }}$ International Scientific Conference: To Consolidate Researches of Academicians and Practitioners, 5 May 2011, Mykolas Romeris University, Vilnius, Lithuania.

- The $13^{\text {th }}$ National Scientific Conference for Young Scientists 'Business in XXI Century' 10 February 2010.

Also, the results of this dissertation were presented in five scientific seminars for doctoral students.

\section{Structure of the Thesis}

The thesis consists of the following parts in the following order: an Introduction, three Chapters, General Conclusions, List of References, and the Summary of the thesis in Lithuanian. The total scope of the dissertation is 135 pages, including 36 Equations, 33 Figures and 9 Tables. For the purpose of the present thesis, references were made to 259 source papers. 


\section{1}

\section{Household Monetary Flows in Financial and Product Markets: Management Problems from the Standpoint of Households and Retail Banks}

This Chapter reflects results of the research analyzing the current state of management of financial resources in households of Lithuania from the standpoint of households themselves and the retail banking. Research on budgetary and borrowing performance of households was performed by analyzing and processing available statistical information and by questionning individuals and households by using sociological methods and tools. Special issues addressed by the research were: the budget management state of households and analysis of reasons compromising its efficiency, features characterising the retail banking market of Lithuania, its volume and borrowing performance of private clients. Special attention was paid in the Chapter to historical analysis of theories supporting the financial resource management in households in order to find the existing gaps. 
Results of investigations in Chapter 1 are published in 3 author's publications (Taujanskaitė, Jurevičienè 2010; Taujanskaitè 2011; Taujanskaitè, Milčius 2012).

\subsection{Comparative Analysis of Household Monetary Flows in Product and Retail Banking Markets}

Households are an important integral part of the economic system of every country; therefore, processes related to households' finances are permanently in the focus of numerous scientists (Campbell 2006; Altfest 2009; Vahidov, He 2009; Abreu, Mendes 2010; Hite et al. 2011; Finke, Smith 2012; Almenberg, Gerdes 2012; Carlin, Robinson 2012; Bosshardt, Walstad 2014) and institutions, such as: Consumer Federation of America (2012), Certified Financial Planner Board of Standards (2012), Members Equity Bank (2013), International Monetary Fund (2013), Wealth Management Institute (2015), and Princeton Survey Research Associates International (2015). Expenditure or consumption planning and management is one of the key elements in household economics (Medova et al. 2008). By efficiently planning and managing its expenditures, a household can achieve maximum utility and successfully implement lifelong wealth building plans and vice-versa.

Table 1.1. shows that the flow of household-related expenditures in Lithuania makes up approximately $2 / 3$ of the country's GDP; therefore, its influence on economics is huge both on the micro and macro levels.

Table 1.1. Relationship between consumption expenditure of households and GDP in Lithuania (created by author according to Eurostat 2016)

\begin{tabular}{l|c|c|c|c|c|c|c|c}
\hline \multirow{2}{*}{ Year } & \multicolumn{7}{|c}{ Level, million EUR (current prices) } \\
\cline { 2 - 9 } & 2008 & 2009 & 2010 & 2011 & 2012 & 2013 & 2014 & 2015 \\
\hline Real GDP & 32696 & 26935 & 28028 & 31263 & 33335 & 34962 & 36444 & 37190 \\
\hline $\begin{array}{l}\text { Household } \\
\text { Consumption } \\
\text { Expenditure }\end{array}$ & 20858 & 18076 & 17892 & 19658 & 20950 & 21968 & 22854 & 23997 \\
\hline $\begin{array}{l}\text { Percentage of } \\
\text { GDP, \% }\end{array}$ & 64 & 67 & 64 & 63 & 63 & 63 & 63 & 65 \\
\hline
\end{tabular}




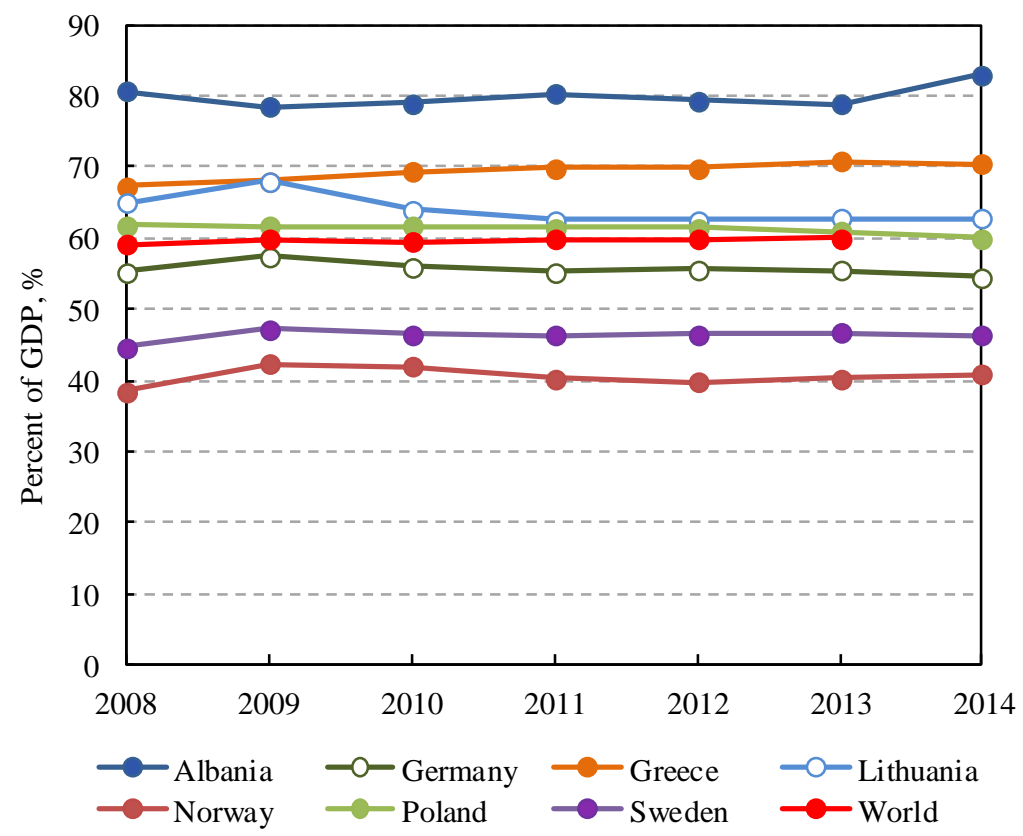

Fig. 1.1. Household consumption expenditure by countries, \% of GDP (created by author according to the World Bank, 2016)

Comparison with other countries shows that Lithuania's index corresponds to the World's average ratio, which is around 60\% (Fig. 1.1).

Figure 1.2 shows that the total revenue of commercial banks from retail and corporate banking makes approximately 0.6 billion EUR per year, while private consumption expenditure is about 21 billion EUR. Thus, an aggregate value of the financial services market makes less than $3 \%$ of the consumer market, while the share of this market related to individuals and households accounts only for $1-2 \%$. In terms of volume, the monetary flow in the product market dominates dramatically, meaning that the involvement of banks in the wealth building of households is rather limited.

Compared to the European Union (EU) countries, the revenue of commercial banks operating in Lithuania is several times lower. It is shown in both cases: if measured as a percentage of GDP (Lithuania 2\%, UK 7.5\%, Germany $4.6 \%$, Nordic countries $4 \%$, Italy 5\%) and as income per capita (Lithuania 200 EUR/year, UK \& Ireland 2300 EUR, Germany 1500 EUR, Nordic countries 1900 EUR, Greece 800 EUR and East Europe 400 EUR) (Wyman 2013). 


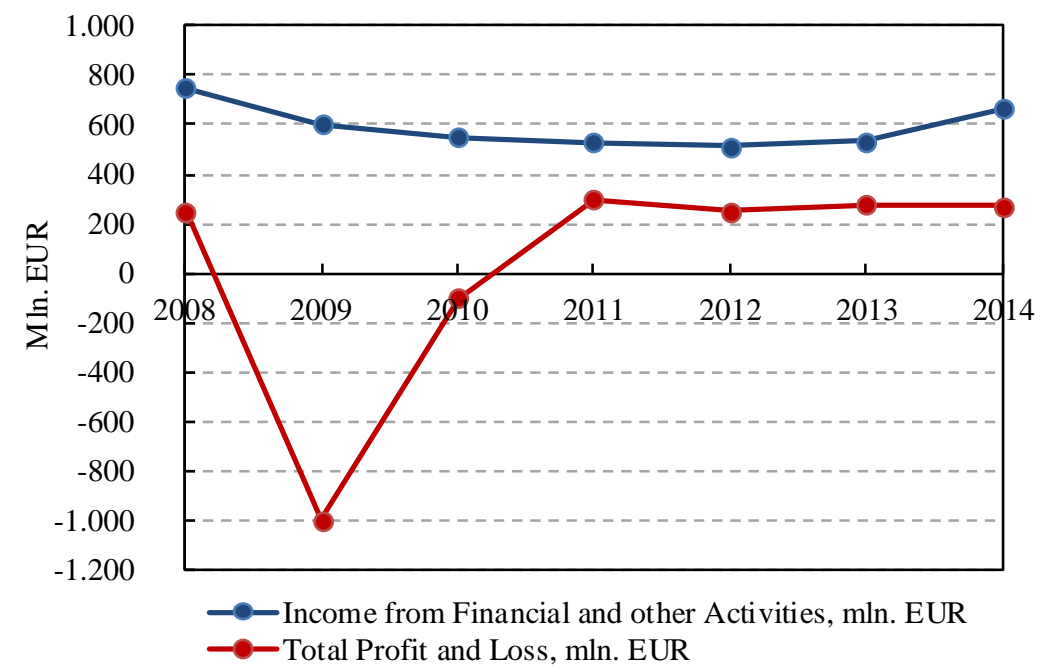

Fig. 1.2. Revenue and profit (loss) of commercial banks and foreign bank branches in Lithuania, mln. EUR (created by author according to the Bank of Lithuania 2015 and Association of Lithuanian Banks 2015)

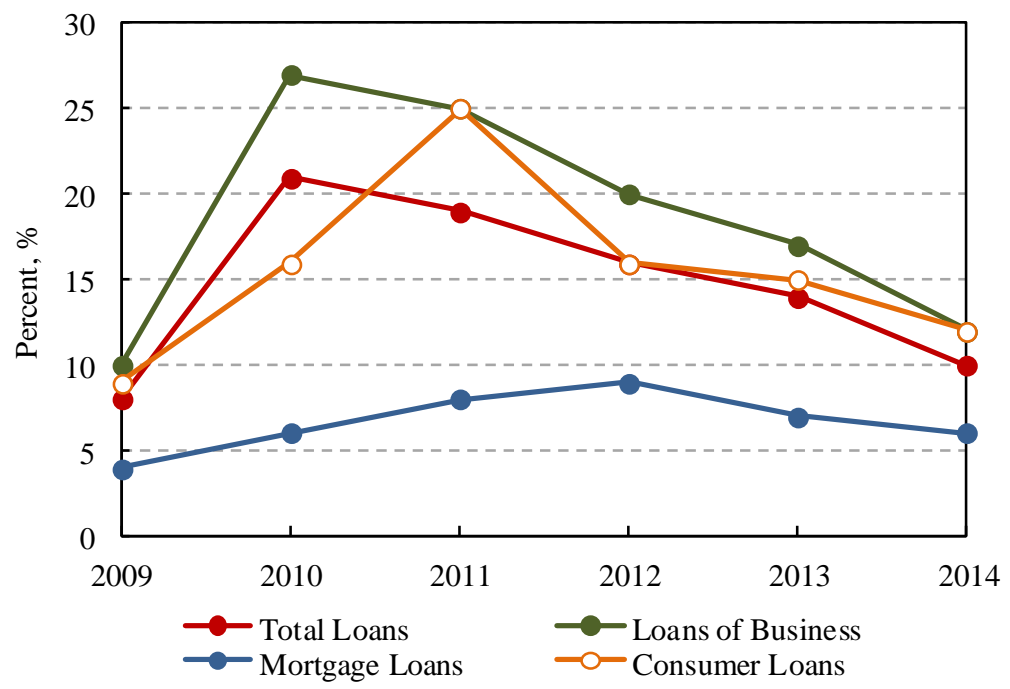

Fig. 1.3. The volume of non-performing loans in commercial banks in Lithuania (created by author according to the Bank of Lithuania 2014) 
Analysis of borrower performance of Lithuanian households has revealed sharply worsening dynamics during the 2008-2010 crisis and rather slow recovery during the post-crisis period. Significant differences exist in mortgage and consumer loan segments with the situation close to threatening in the latter segment, where the level of bad loans had reached 25\%. The situation had improved since 2012, but the volume of non-performing loans still remains high, reaching $9.8 \%$ (Fig. 1.3). This has a strong influence on the profitability of banks. Currently, the profitability of financial institutions has recovered, and the profit level reached almost 250 million EUR in 2014. However, all the profitable years starting from 2011 have hardly compensated for the loss suffered in the years 2009-2010 (Fig. 1.2).

Non-performing loans (NPL) are a painful problem not only in Lithuania but in other countries as well. Figure 1.4 illustrates the dynamics of the level of non-performing loans in the period of 2008-2015 in nine countries.

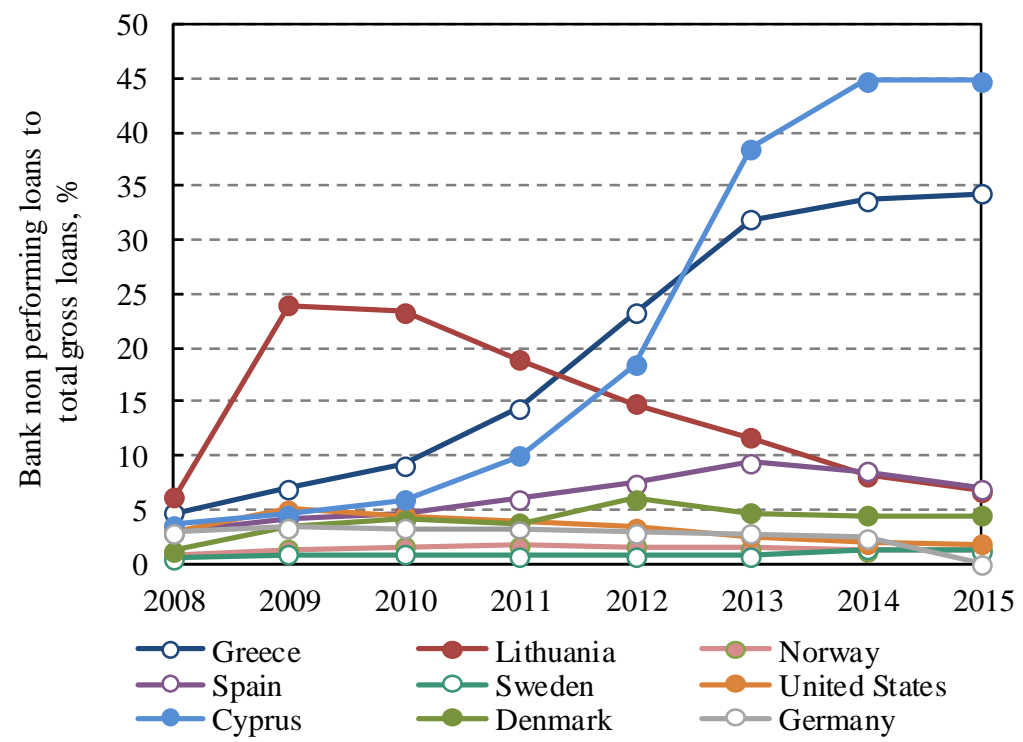

Fig. 1.4. Bank nonperforming loans to total gross loans in different countries in 2008-2015 (created by author according to the World Bank 2016)

In 2009, the NPL level in Lithuania was the highest among these 9 countries. Starting from 2011, a sharp NPL growth was registered especially in Cyprus and Greece. At the end of 2015, the NPL level in Cyprus was 45\%, and in Greece the NPL level was 34\%, while countries like Sweden or Norway have never had a NPL level higher than $2 \%$ during this period. 
The analysis shows that the problem is really widespread and common in the various EU countries.

\subsection{Research on the Finance Management State in Households under a Changing Macroeconomic Environment}

The inside processes related to the households' finances and their control are permanently in the focus of many researchers:

- Various aspects related to households' income and expenditures have been investigated in publications by C. Bigda, G. Mannes, W. Updegrave (2010), A. Underwood (2010), L. Altfest (2009), T. Ramanauskas, A. Jakaitienė (2007), A. Hall (2006), E. Faerber (2005), A. Deaton (1992) and others.

- Aspects related to the saving of households' financial resources were discussed in publications by E. Tyson (2010), M. G. Gordon (2008), L. J. Gitman, Ch. Mazer (2007), G. Helly (2007), B. Winger, R. R. Frasca (2006), D. Harrison (2005), as well as A. V. Rutkauskas, V. Stasytyte (2011), K. Taujanskaitè, D. Jurevičienè (2010), O. G. Rakauskiené, E. Bikas (2007), A. Maldeikienè (2005) in Lithuania.

- Investment related issues of household savings are among the most important ones and are permanently in the focus of both researchers and practitioners in this sector. Publications on investment management by A. V. Rutkauskas, G. Žilinskij (2010), A. E. Ody (2010), C. Yacht, R. Siegel (2010), A. V. Rutkauskas, A. Miečinskienė, V. Stasytytė (2008), J. Stankevičienè et al. (2009), L. J. Gitman, M. D. Joehnk (2007), Z. Bodie, A. Kane, A. J. Marcus (2003) and many others cover all the aspects significant for making decisions related to investment.

The majority of the above and numerous other publications are mainly based on a fundamental approach to personal finance management and do not specifically target decision-making mechanisms in a specific household affected by permanently changing conditions on global financial markets or macroeconomic processes in a specific country.

Specific financial conditions of Lithuanian households have been analysed first of all by A. V. Rutkauskas (1999), then by D. Jurevičienè, E. Gausienè (2010), E. Bikas, A. Kavaliauskas (2010), etc. In other countries, J. Titko, N. Lace, T. Polajeva (2015) have analysed financial issues perceived by youth and evaluated the financial literacy of young people in the Baltic States. E. Fornero and C. Monti- 
cone (2011) have investigated financial literacy and pension planning in Italy, S. Sekita in 2011 also analysed similar aspects in Japan. Not only researchers, but also organizations pay attention to the importance of financial litearacy and investigate various aspects of it. In 2004, the Financial Services Authority (FSA) announced that it would commission a 'comprehensive baseline survey to establish the current state of financial capability in the UK'. The FSA subsequently asked the Personal Finance Research Centre to carry out an exploratory qualitative study to design a questionnaire that could be used to measure levels of financial capability of individuals (Financial Services Authority 2005). ANZ/The Social Research Center (2011) analysed adult financial literacy in Australia. The Organisation for Economic Cooperation and Development (OECD) in 2012 has made a pilot study in order to measure financial literacy in 14 different countries (Atkinson, Messy 2012). Relevant statistical data and related process analysis about household finance management aspects is permanently in focus of local banks in Lithuania (e.g. SEB bank, Swedbank) as well as institutions involved in financial activities and statistics. Statistics Lithuania used to carry out annual research on household budgets until 2008 (Statistics Lithuania 2008). The Ministry of Finance of the Republic of Lithuania, on the other hand, prepares the generalised predictions related to the financial state of households (2011), but it does not analyse the decisionmaking process inside the household. The Securities Commission of the Republic of Lithuania until its liquidation in 2011 has been performing annual researches on households financial literacy. Since 2011 this research is being performed by the Bank of Lithuania (2015). Since 2010, the analysis of households' financial condition has been performed by the bank 'Swedbank AB' through its Institute of Private Finances, and since 2011, the SEB bank initiates investigations about household finances called the 'Baltic Household Outlook'.

The above mentioned institutions mainly focus on generalised information, representing conditions of the entire spectrum of households without analysing the processes specific to a certain group of households with a certain income, wealth, etc.

The decision-making process related to the control of household budgets is very complex and has no single solution in general. This process is very much related to human psychology (Griškevičius et al. 2010), and emotional triggerfactors might have a strong influence. The analysis of households' behaviour and efforts taken to control their budgets under the influence of the instability of financial markets might produce valuable information on the level and proportions of influence of macroeconomic factors on the household's decisions.

Analysis of transformation of financial behaviour of Lithuanian households during the 2008-2010 crisis has been performed by using sociological methods and specially drafted questionnaires. 


\subsubsection{The Setup of Research}

In order to collect the required data, two identical, in terms of methodology, sociological surveys were conducted: first - in the beginning of the year 2009, when the crisis in Lithuania had reached an apogee and another - by the end of the year 2010 when the crisis was approaching an end. The first and the second questionnaires are displayed in Annex F and Annex G.

The questionning technology was based on specially arranged questionnaires, containing specially drafted questions. In order to obtain the survey results, which would be sufficiently reliable and would adequately reflect information on all the $3.3 \mathrm{mln}$. citizens of Lithuania (2009), a special confidence level was set to be at least $95 \%$ and a minimal number of respondents was calculated. To meet the set reliability indicator, at least 200 respondents should submit their information, which should guarantee an error within 6.9\% limits (Customsight 2011). In both cases, this requirement was met.

The study from May 2009 revealed the following problematic issues related to the management of household budgets:

- A clearly displayed non-systemic and poorly motivated character of spending, which has resulted in unexpectedly large amount of unbalanced household budgets. A large number of households faced difficulties with the control of spending even when their income was aboveaverage.

- A lack of skills related to the investment of savings and a very limited variety of investment tools used. The majority of household savings were kept in demand deposit accounts and part of them in savings accounts while investment in securities was used on limited scale.

- A lack of knowledge and skills within individual asset liability management.

The study was repeated at the end of 2010, and the two results were compared in order to find out the changes and trends caused by the crisis.

\subsubsection{General Information about Respondents}

General data covers the information regarding the respondents' age, gender, education, residence and monthly income.

The age of the respondents was within the range 20-65 years old. To maintain the right proportions between the residents of big cities and rural areas, the respondents were selected according to the random sampling method (Waksberg 2011). The number of respondents was exactly the same in both surveys: therefore, this should not cause any additional errors. 
The general characteristics of respondents in both studies were quite similar. Data from 2010:

- Percentage of respondents by gender: men $-48.25 \%$ (in 2009, men $55.28 \%$ ), women $-51.75 \%$ (in 2009, women $-44.72 \%$ ).

- Percentage of respondents by education: graduates of universities $81 \%$; students of universities $-9.5 \%$; graduates of college $-5.5 \%$; graduates of secondary school $-3.5 \%$ (in 2009, graduates of universities $79 \%$; students of universities $-11 \%$, graduates of college $-6.5 \%$; graduates of secondary school $-3.5 \%$ ).

- Average age of respondents - 32 years (2009 survey - 30 years).

Both questionnaires were placed on a special webpage www.apklausa.lt, which meant that first of all, people with good access to the Internet and who had skills in using IT tools would dominate among the respondents. One possible negative aspect from using this technology might be that the results are not bias-free due to the non-uniform representation of all the population, comprised of those using and not using IT tools.

Respondents represent a highly educated part of the population, well above average, which means their behaviour could be considered reliable and motivated This also suggests that the obtained results should be reasonably reliable and should adequately reflect the households' reactions induced by the crisis.

\subsubsection{State of Household Budget Management: Efficiency and Trends under Effect of Financial Crisis}

The results were processed and analysed to determine the changes within personal finance management during the years 2008-2010.

Respondents' monthly income varies from 144 EUR to 1450 EUR and more while the majority earn between 290 EUR to 434 EUR per month, and in 2010, this amount has increased from $18 \%$ to $22 \%$ (Fig. 1.5). In addition, there was a significant increase of $41.67 \%$ in individuals with income between 580 EUR and 724 EUR, followed by a 9\% decrease in people who earn (or get) the lowest income. The number of respondents whose monthly income is between 870 EUR and 1159 EUR is the same in 2009 and 2010, but there was a decrease in high-income respondents. For example, in 2010, $40 \%$ fewer respondents earn 1160-1449 EUR, and only half of them earn more than 1450 EUR compared to 2009.

Even if the average income of respondents fell by 6.63\%, from 539 EUR in 2009 to 503 EUR in 2010, it is still above the average income of the Lithuanian population, which during the year 2010 has increased to 464 EUR from 459 EUR in 2009. The compared results of these figures might look contradicto- 
ry, but they can be explained quite easily. The majority of respondents are young, highly educated and economically active people whose average age is 32 years. Likely, this has led to higher income compared to the statistics. The observed decline in average income can be explained by the fact that a significant decrease was registered in the interval diapason of individuals with the highest (1161 EUR and more) income.

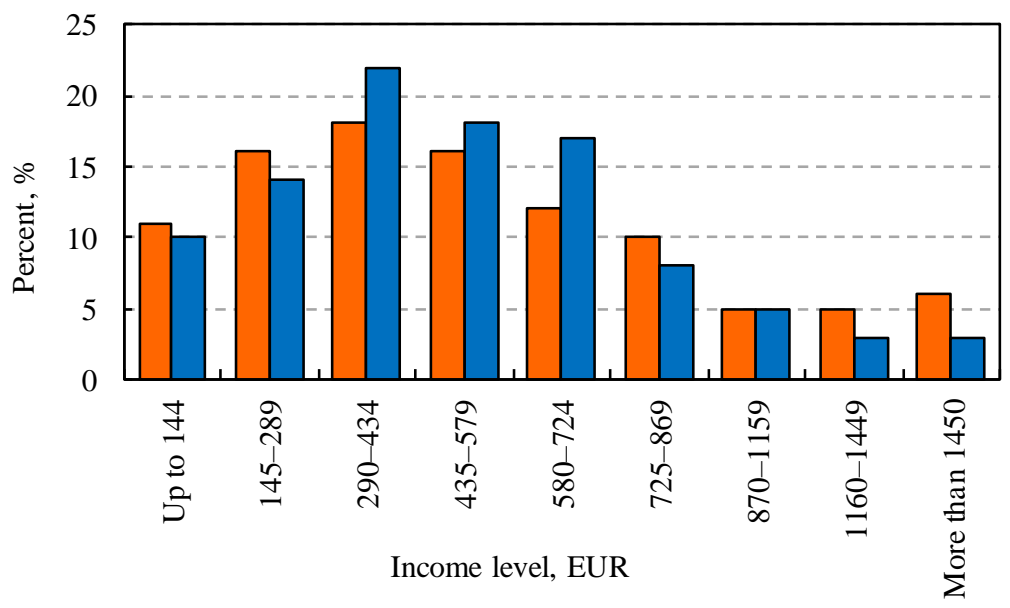

$\square$ Share of households, year $2009 \square$ Share of households, year 2010

Fig. 1.5. Monthly income of the respondents (source: author)

The main outcome about changes of income during the crisis is that it became more 'compact' with a significantly reduced number of individuals with very low and very high earnings.

A special block of questions was designed to find out how crisis has changed the households' ability to balance their budgets (Fig. 1.6). Figure 1.6 illustrates that in $2009,32 \%$ of households had a budget deficit, but in 2010, this index fell to $26 \%$.

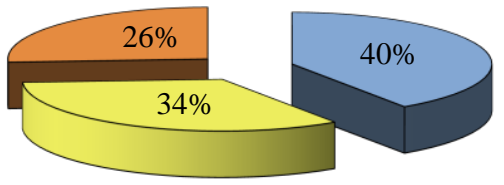

a)
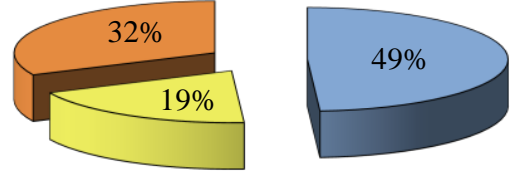

b)

$\square$ Expenses were lower than income

$\square$ Expenses were equal to income

$\square$ Expenses were higher than income

Fig. 1.6. Changes in household's budget balance: a) 2010, b) 2009 (source: author) 
Figure 1.7 indicates a huge diversity and quite contradictory results gained when analysing the households with different income levels. As was mentioned before, the previous survey of the year 2009 discovered that, contrary to expectations, the largest share of households suffering from a budget deficit (32\%) was found among those with the highest income while even the respondents with the lowest income were more successful from this point of view. Households with a middle income level between 450 EUR and 850 EUR demonstrated the best performance. By the end of the crisis in 2010, the situation almost did not change in the low-income households, even though it would not be surprising to see them in a much worse state because of increased prices. Middleincome households demonstrated even better performance compared to the previous survey, reducing their share of deficit budgets by $13 \%$, while high-income households suffered from deficits more than in 2009. The share of deficit budgets within this category increased by $12.5 \%$, reaching $37.5 \%$, which is 1.45 times more than the corresponding share in the low-income $(25.8 \%)$ and 2.8 times more than in the middle-income (13.4\%) households. A more accurate analysis shows that the zone in which the rational behaviour dominates had expanded and covered not only middle-income households but also some part of households with income equal to or exceeding 850 EUR while the performance of those with income around 1500 EUR was very poor. The situation within households having income higher than 1500 EUR seems to be much better, but due to the limited number of respondents, it is difficult to make firm generalisations.

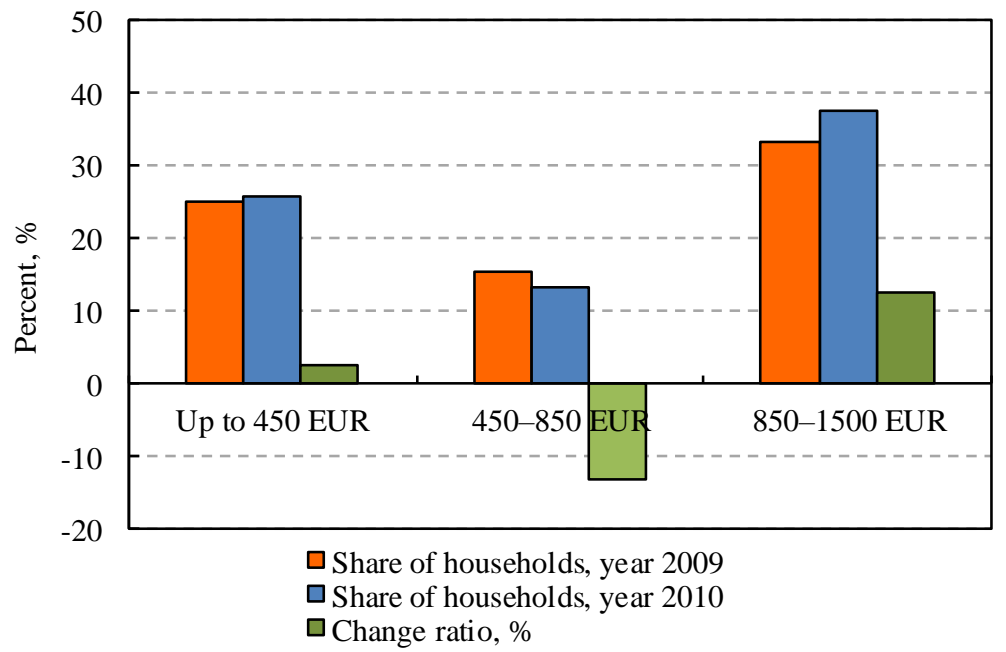

Fig. 1.7. Households with budget deficit in 2009-2010 (source: author) 


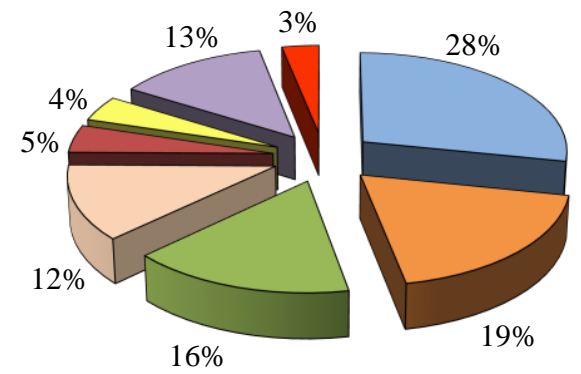

a)

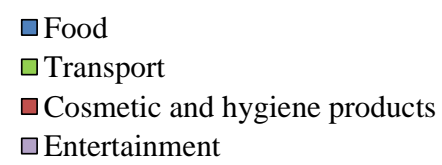

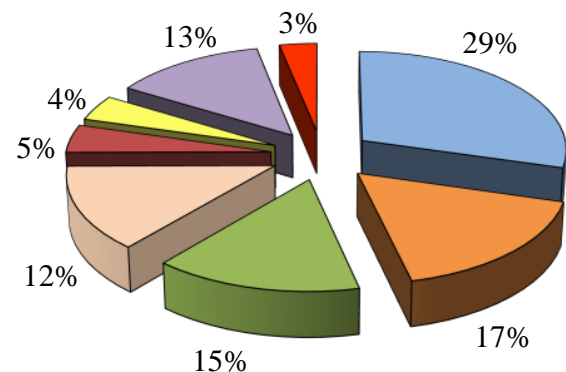

b)

Fig. 1.8. Distribution of expenditure by needs: a) 2010, b) 2009 (source: author)

The distribution of household expenditure by needs can be seen in Figure 1.8.

Similar to the previous survey, the nutrition, municipal services and transport costs made the biggest part of the expenditure with nutrition being in the first place, and municipal and transport costs in second and third, respectively. The 2009 survey produced similar results showing that $29 \%$ of expenditure was used on food, municipal costs made $17 \%$ and transport costs $15 \%$, which was very close to spending for clothing and shoes. The latter survey observed a decrease in spending on clothing and shoes by $14.29 \%$, an increase for municipal services by $11.76 \%$, and an increase for transport costs by $6.67 \%$.

There is a good correlation with the results from the survey by the Swedbank Private Finance Institute of October 2010, which found that the main structure of household expenditure mainly consists of food products and nonalcoholic beverages (34\%), costs of household maintenance (17\%) and expenses for transportation and fuel (8\%) (Swedbank Personal Finance Institute 2010).

A comparison of results from the two studies shows that the relative cost of physiological needs compared with total expenditures has risen relatively and indicates more conservative behaviour of households.

Another block of questions concentrates on households' attitude towards saving. Respondents were asked whether they have saving plans. 


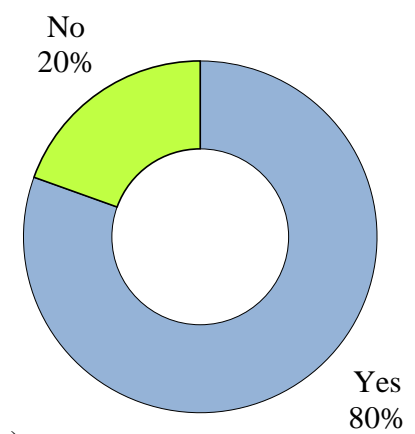

a)

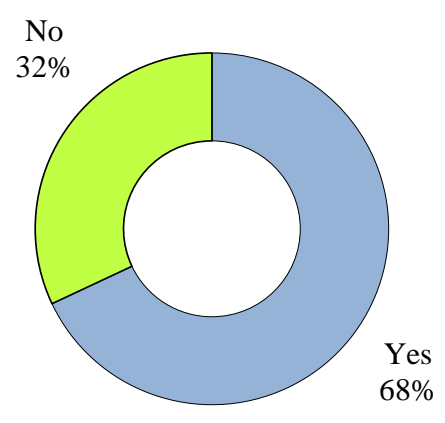

b)

Fig. 1.9. Answers regarding saving plans : a) 2010, b) 2009 (source: author)

Figure 1.9 shows an increase of households who have set their saving plans from $68 \%$ to $80 \%$ in 2010 ; the increase is equal to about $17.65 \%$. In addition, there was a $37.5 \%$ decrease in respondents who do not save at all, which is quite remarkable taking into account that the average income over the period has decreased by $6.63 \%$.

The question about used saving instruments was answered by the respondents as shown in Figure 1.10.

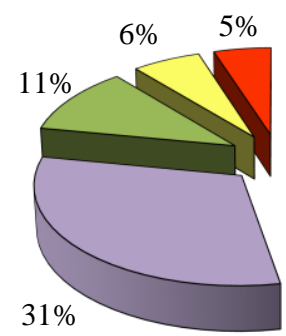

a)

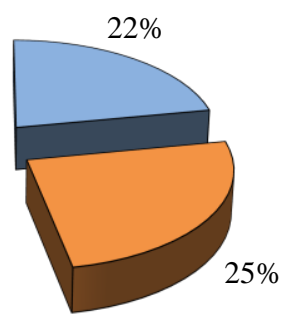

$25 \%$

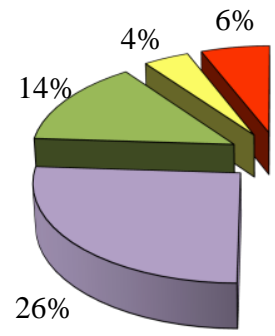

b)

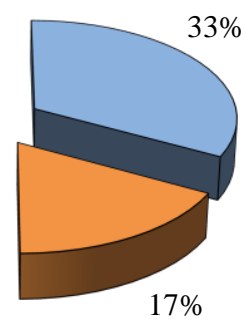

$17 \%$
$\square$ Savings in personal current account
$\square$ Savings at home
$\square$ Savings in deposit account
$\square$ Other
$\square$ Savings invested in securities or alternative investments
$\square$ Investing money in life insurance

Fig. 1.10. Changes in saving and investment instruments applied: a) 2010, b) 2009

(source: author) 
Figure 1.10 shows that the situation in the savings sphere has significantly changed. Comparing the number of respondents who save by transferring cash into a current bank account, we see a 30.3\% decline (2009-33\%, 2010 - 23\%). Up to a $50 \%$ increase was registered in people who buy stocks or bonds despite a very negative overall environment. This could be explained by people having better awareness of investment mechanisms. At the same time, the number of those who chose other alternative investments, such as collectables (art, wines, horses, etc.) has declined by $21.43 \%$. Additionally, in 2009 the percentage of people who preferred life insurance for investing their money was higher. Currently, this number has declined by $16.67 \%$. Also, there was even a $47.06 \%$ increase in those who chose to keep their savings at home and an increase of $15.38 \%$ in the number of respondents who keep their free cash in fixed bank deposits.

This indicates that the variety of popular saving options in Lithuania is becoming wider but is still limited, and the way households distribute the accumulated free cash is rather conservative. It is obvious that sharp drop in stock values did not encourage a large portion of those who could potentially invest in financial markets. This percentage still remains low. Consequently, distrust has increased in any riskier investment alternative. This could explain the sudden and widespread tendency of keeping free cash just at home.

An attempt was made to find reasons behind households' non-saving behaviour.

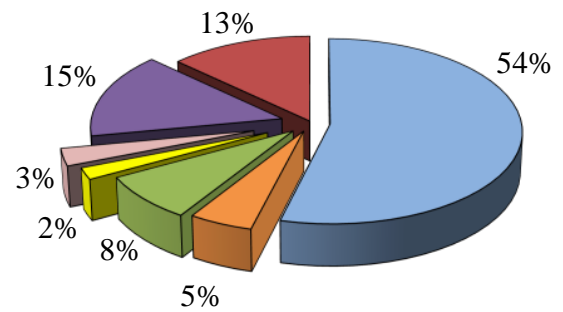

a)

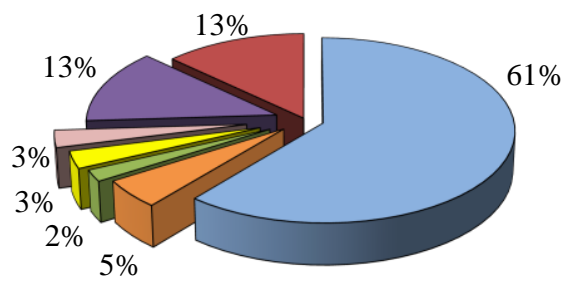

b)

$\square$ I spend all my money for consumption
$\square$ I don't think it is necessary for me
$\square$ Afraid of total or partial loss of savings
$\square$ Insufficient qualification of financial consultants
$\square$ Afraid of cheating
$\square$ Lack of financial knowledge
$\square$ Other

Fig. 1.11. Reasons for refusal of saving: a) 2010, b) 2009 (source: author) 
It appears (Fig. 1.11) that even 53\% of respondents who otherwise would prefer saving, do not save because all their income is being spent on consumption. However, this number has decreased by $13 \%$ compared with the previous survey. A dramatic, even 2.7 times (from 3\% to 8\%) increase was registered in people who were afraid to fully or partially lose their savings, and this was the reason why they have decided not to save at all. An interesting observation was that a number of people who refused to save just because they felt a lack of financial knowledge increased by $15 \%$, which means they have realized the role and importance of adequate knowledge and skills within finance management.

A special block of questions was designed to investigate the respondents' opinion on how they would evaluate their knowledge within personal finance management (Fig. 1.12).

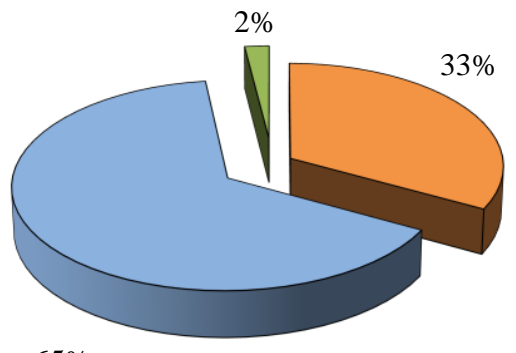

$65 \%$

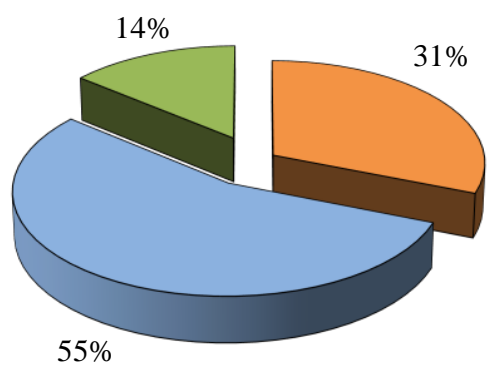

b)

a)

$\square \mathrm{I}$ know enough $\quad \square \mathrm{I}$ know a little $\square \mathrm{I}$ know nothing

Fig. 1.12. Knowledge within personal finance management as estimated by respondents themselves : a) 2010, b) 2009 (source: author)

The answers show that there was a $6.45 \%$ increase in the number of people who think their knowledge about personal finance management is sufficient. The most significant decrease, equal to $85.71 \%$ (from $14 \%$ to $2 \%$ ) was in the number of respondents who know nothing about it while the number of those who lack adequate financial knowledge has increased by $18.18 \%$. Most likely, the results are such because of respondents who had no knowledge at all during the previous survey. This indicates obvious progress and positive changes; nevertheless, the need for education to improve financial management skills is still high. 


\subsection{Management Problems of Household Expenditure and their Causes}

\subsubsection{Related Theoretical Concepts}

The historical overview was performed by combining a look into original investigations parallel with their evaluation given by modern researchers from the point of view of contemporary science.

As stated by Parker (2010), there is no topic in macroeconomics that has a longer, deeper, or more prominent literature than households' choice of how much of their income to consume. Consumption related issues have been investigated for centuries. The beginning of research about household consumption can be traced to Nicholas Bernoulli, John von Neumann and Oskar Morgenstern's work The Basis of Consumer decision-making Theory, published in 1715 (Richarme 2005), which contained the first formal explanation of consumer decision-making. Later, in 1738, Daniel Bernoulli extended this concept and formulated Utility Theory, which proposed that 'consumers make choices based on the expected outcomes of their decisions. Consumers are viewed as rational decision makers who are only concerned with self-interest' (Salvatore 2008; Schiffman, Kanuk 2007; Zinkhan 1992). Utility theory views the consumer as a 'rational economic man' (Zinkhan 1992), although perception of the rationality appears to be quite flexible as the consumer's behaviour can be influenced by numerous intrinsic and extrinsic factors.

In 1857, German economist Ernst Engel noted in his investigation Reliance on Income Level and Expenditure Composition that 'when family's income increases, the proportion of money spent on necessities proportionally decrease, but at the same time the expenditure for luxury things increases' (Zimmerman 1932).

In 1834, intertemporal choice theory was introduced by John Rae in the Sociological Theory of Capital. Later, Eugen von Böhm-Bawerk in 1889 and Irving Fisher in 1930 elaborated on this model. Irving Fisher developed the theory of intertemporal choice in his book Theory of Interest (1930). The main ideas of this theory were: a) the consumer chooses current and future consumption to maximise satisfaction of lifetime subject to an intertemporal budget constraint; and b) current consumption depends on lifetime income, not current income, provided the consumer can borrow and save (Mankiw 2013).

Research in personal finance started as early as in the 1920 s by Hazel Kyrk who actually laid the foundation for the field of family and consumption (or consumer) economics. Kyrk's dissertation and her later work triggered the development of family economics (Kyrk, 1923, 1933). Beller and Kiss (Beller, Kiss 1999) recognize her role in incorporating the insights of economics into the 
field of home economics and creating the Division of Family Economics in the American Home Economics Association.

The input of Margaret Reid, 1934, another Chicago economist, in several areas of consumer and household behaviour is also widely recognized as significant (Hira 2009).

The framework for consumer theories was made by British mathematician and philosopher Frank P. Ramsey (1928) and British economist John M. Keynes (1936). Samuelson (1970) remarks the significance of the publication in The Economic Journal, which contained 'a strategically beautiful application of the calculus of variations' to determine the optimal amount an economy should invest (save) rather than consume so as to maximise future utility, or in Ramsey's words 'how much of its income should a nation consume and how much save?' (Ramsey 1928). The theory of consumption is central to the model of Keynes's General Theory, which is often considered the origin of macroeconomics. Since then, it has been the subject of countless theoretical and empirical studies. Keynes treated consumption on a very 'common sense' level. Like most other economists of his days, his methodology included neither abstract, mathematical theory, nor detailed econometrics. Rather, he relied almost entirely on intuition as he demonstrates when he introduces the central principle of his consumption theory (Parker 2010): 'The fundamental psychological law, upon which we are entitled to depend with great confidence both a priori from our knowledge of human nature and from the detailed facts of experience, is that men are disposed, as a rule and on the average, to increase their consumption as their income increases, but not by as much as the increase in their income' (Keynes 1936). In the book The General Theory of Employment, Interest and Money, Keynes noted that 'individuals' or families' consumption and saving behaviour in a given period is related only to their disposable income of that same period' (Baranzini 2005). Keynes described this thesis in his Absolute Income Hypothesis in 1936. Keynes gives no basis for his theory in terms of utility maximization nor indeed gives any consideration of why a consumer would behave in the way he assumes. In place of rational-choice theory, Keynes relies on his 'knowledge of human nature'. Nor does he give any support using numerical data, but he instead claims to glean support from 'detailed facts of experience' (Parker 2010).

At about the same time, Nobel Prize winner Simon Kuznets (1951) refined national account measures of income and consumption and pointed out a paradox that could not be explained by the simple linear consumption function, as it was suggested in the Keynes model. The Kuznets paradox was that the percentage of disposable income that is consumed is remarkably constant in the long run, which suggests a proportional consumption function. However, estimates across individual households or using short-run aggregate time-series fluctuations in income and consumption consistently produce estimates, which means that the share of income consumed declines as income rises. Explaining the 
Kuznets paradox became a primary goal of consumption theorists in the 1950s (Parker 2010).

In 1947, Nobel Prize winner American economist, psychologist, sociologist Herbert Simon formulated the theory of individuals financial decision formation and analysed how organisations and individuals make financial decisions. $\mathrm{He}$ suggested that the decision-maker possessed limited information (knowledge) and did not always seek the best potential choice because of limited resources and personal inclinations. Simon claims that 'decision-making $<\ldots . .>$ must be derived from the logic and psychology of human choice'. He argued that 'the task of rational decision-making is to select the alternative that results in the more preferred set of all the possible consequences. This task may be divided into three required steps: 1 . the identification and listing of all the alternatives; 2 . the determination of all the consequences resulting from each of the alternatives; 3 . the comparison of the accuracy and efficiency of each of these sets of consequence' (Simon 1976). Any given individual or organisation attempting to implement this model in a real situation would be unable to comply with the three requirements. It is highly improbable that one could know all the alternatives, or all the consequences that follow each alternative. The resulting question would be as follows: given the inevitable limits on rational decision-making, what other techniques or behavioural processes can a person or an organization bring to bear to achieve approximately the best result? Simon writes, 'The human being striving for rationality and restricted within the limits of his knowledge has developed some working procedures that partially overcome these difficulties. These procedures consist in assuming that he can isolate from the rest of the world a closed system containing a limited number of variables and a limited range of consequences' (Simon 1991). Later, in the mid-1950s, Herbert Simon presented his model, which was called Satisficing, in which consumers went approximately where they wanted to go and after that cancelled the decisionmaking process. Simon and others have extended this area in the investigation of the field of bounded rationality (Richarme 2005).

The Relative Income Hypothesis developed by James Duesenberry (1949), states that consumption depends not only on absolute income but also on relative consumption patterns determined by the position in income distribution (Tapsin, Hepsag 2014). This hypothesis enjoyed considerable popularity in the 1950s, but it is not discussed much anymore (Parker 2010).

Since about the 1950's, the notion of consumer behaviour has responded to the conception: 'Consumer behaviour $<\ldots>$ is the study of the processes involved when individuals or groups select, purchase, use or dispose of products, services, ideas or experiences to satisfy needs and desires' (Solomon et al. 2006). Schiffman and Kanuk (2007) take a similar approach in defining consumer behaviour: 'The behaviour that consumers display in searching for, pur- 
chasing, using, evaluating, and disposing of products and services that they expect will satisfy their needs'.

Two other theories pioneered by Nobel laureates, the Life-Cycle model associated with Franco Modigliani and the Permanent-Income Hypothesis developed by Milton Friedman, were easier to reconcile with the micro-foundations of consumer choice. These two theoretical approaches have largely merged to become modern consumption theory (Parker 2010). Franco Modigiliani, Albert Ando and Richard Brumberg investigated household consumption and in 1954 presented the Life Cycle Hypothesis. They claimed that: a) a household's income varies systematically over a lifetime; b) consumers use saving and borrowing to smooth consumption; and c) consumption depends on income and wealth (Modigliani, Brumberg 1954; Ando, Modigliani 1957).

Milton Friedman also investigated household consumption issues and in 1957 suggested the Permanent Income Hypothesis. The main ideas were: a) household consumption mainly depends on permanent income; b) consumers use saving and borrowing to smooth consumption and minimize the effect of income fluctuations (Meghir 2004). The difference between this hypothesis and life-cycle hypothesis is in that the life-cycle theory emphasized natural variations in earnings over a finite lifetime whereas the permanent-income model stressed general variations in income over an indefinite horizon (Parker 2010).

In the 1960s, Garry Becker was the one who 'put the family on the economics profession's research agenda' (Pollak, 2002). Becker (1965) is best known for modelling household decisions and resource allocation in a model where a household is both a producing and consuming unit. Huffman (2010) points out the parallelism with Margaret Reid's (1934) earlier research and considers her work to be an important antecedent to Becker's formal modelling of the productive household. Becker has demonstrated the researchability of the family from the economic side and described what he has termed the 'economic approach' to the family. He wrote, 'The economic approach $\langle\ldots .$.$\rangle assumes that$ individuals maximise their utility from basic preferences that do not change rapidly over time, and that the behaviour of different individuals is coordinated by explicit and implicit markets' (Becker 1993). The theory distinguishes three main components that constitute household economics: household production, consumption and time allocation. Household production relates to all the output that a household produces, including production related to work. Household consumption includes all things that are consumed by a household including food, sleep, leisure, etc. Time allocation refers to the exact way we spend each minute of our day. Time allocation also introduces the basic concept of opportunity cost, explaining that every minute we allocate to one activity, by definition, cannot be allocated to any other activity". An approach based on the inclusion of production, consumption and time, allows economists to create models that examine the correct allocation of goods and services (Simple Economist 
2015). It reflects the fundamental concept in consumer economics. By utilising it, researchers are able to identify and examine how consumers behave, and it helps households understand the opportunity costs of their time allocation (Lazear 2000). Pollak (2002) admits that the foundational assumptions of Becker's economic approach to the family - maximising behaviour and equilibrium as well as primary auxiliary assumptions such as household production and interdependent preferences, are now widely accepted not only by economists, but also by family sociologists, demographers and others who study the family.

Becker's theory has been criticized by other scientists, e.g. R. A. Pollak (1975, 1985), J. Behrman et al. (1995), S. Lundberg (2001) and others mainly because of his assumptions and analytical methods used (Pollak 2002). Bergmann (1995) notes that some of Becker's assumptions make analysis too simple and 'eaves out considerations of prime importance'. Nevertheless, as stated by Pollak, 'Although we may reject many of Becker's answers and refashion many of his tools, but his answers and his tools provide the starting point for economists who work on the family'.

In 1961, John Muth formulated Rational Expectations Theory. Robert Lucas was awarded the Nobel Prize in 1995 for its further development (Syll 2011). This economic theory is based on the assumption that people make financial decisions according to their monetary resources and do not make mistakes. Besides, individuals use all available information in the market for such decisions, and they are based on their intelligence not on psychological aspects (Lovell et al. 2011). According to T. J. Sargent (2008), there are substantial differences compared with Keynes's General Theory, where expectations were treated as irrational because they existed in the minds and were analysed as a psychological phenomenon.

Consumer Theory explains how a rational consumer makes consumption decisions (Levin, Milgrom 2004). It is a theory showing how people decide what to spend their money on given their preferences and their budget constraints (Nicholson 2005). Consumer theory clarifies how individuals make choices given their income, and the prices of goods and services and helps us to understand how individuals' tastes and incomes influence the demand curve (Echenique et al. 2011). Consumers can choose different bundles of goods and services. Logically, they will choose the bundle that gives them the greatest benefit (that maximises utility, in economic parlance) (Dean 2009). Consumer choice theory is a way of analysing how consumers may achieve equilibrium between preferences and expenditures by maximising utility as subject to consumer budget constraints (Silberberg 2001).

The Preference Approach, which was developed by P. Samuelson, is a method by which one can discern a consumer's utility function by observing his or her behaviour. Rather than postulate a utility function or a preference ordering, Samuelson imposed conditions directly on the choices made by individu- 
als - their preferences as revealed by their choices (Samuelson 1938, Varian 2006).The theory assumes that a consumer has a well-defined set of desires, or 'preferences', which can be represented by a numerical utility function. Furthermore, it is assumed that the consumer chooses optimally by giving preference to the option with the highest utility of those available. This means that a consumer is involved in permanently solving the optimisation problem (Dean 2009).

In 1966, mathematical-economist Kelvin John Lancaster developed Modern Consumption Theory, which he called a 'new theory of consumer demand' and claimed that 'what consumers are seeking to acquire is not goods themselves, but the characteristics they contain' (Lancaster 1966). As Palda (2013) explains, 'the second evolution in spatial economics was due to Kelvin Lancaster. His insight was that the basic qualities that consumers seek could be manipulated by combining different products. He had been content to accept that one good provided one underlying feature that could be measured in characteristics space'.

Following H. Simon, additional efforts were made to develop a better understanding of consumer decision-making, extending beyond the mathematical optimisation of utility theory and the somewhat unsatisfying satisficing theory. In the late 1970s, two leading psychologists, Daniel Kahneman and Amos Tversky, developed the Prospect Theory, which expanded upon both the utility theory and the satisficing theory and became a new theory that encompassed the best aspects of each while solving many of the problems that each presented (Richarme 2005).

In 1978, Robert Hall presented the Random Walk Hypothesis. It combines the results of the permanent income hypothesis with a rational human's expectations and shows that the changes in consumption are unpredictable and occur only in response to unanticipated changes in expected permanent income.

Conventional financial theories presume that individuals are rational, able to choose the preferences and are, for the most part, rational 'wealth maximisers' (Buskens 2015), or an individual may get the definition 'economic man' (Homo economicus) (Sutherland 2012). This is not always supported by practice, where decisions are often influenced by emotions and psychology, causing unpredictable or irrational behaviour. Behavioural finance is the study of the influence of psychology on the behaviour of financial practitioners and the subsequent effect of their behaviour on financial markets (Sewell 2007). It seeks to combine behavioural and cognitive psychological theory with conventional economics and finance to provide explanations that clarify why people make irrational financial decisions (Phung 2011), but do not suggest the ways how to minimize irrationality. Earlier 'economic psychology' was trying to bring together insights from both psychology and economics (Lea, Newson 2006). Various aspects, which differ in the conventional and behavioural finance theories, were analysed by Lea and Newson (2006), Ricciardi and Simon (2000), and by the others. 
Maslow (1943) analysed individuals' behaviour only from the perspective of psychology without involvement of economics. The Hierarchy of Needs he developed $(1943,1954)$ comprise five motivational levels of needs, often depicted as hierarchical levels within a pyramid. This five-stage model can be divided into basic (or deficiency) needs (e.g. physiological, safety, love and esteem) and growth needs (self-actualisation). The deficiency, or basic needs, are said to motivate people when they are unmet. In addition, the aspiration to fulfil such needs will become stronger the longer the duration the basic needs are denied. One must satisfy lower-level basic needs before progressing on to meet higher-level growth needs. Once these needs have been reasonably satisfied, one may be able to reach the highest level called self-actualisation (Mcleod 2007). Such a prioritisation of needs is based on strong logics, which is difficult to argue with. Nevertheless, an analysis of financial behaviour carried out in Lithuanian households (Taujanskaite, Milčius 2012) presents a picture in which the purchased goods and services, it seems, must meet a mixed bunch of needs. This bunch is usually related to items that meet both the lowest and highest levels of needs, and which often result in an unbalanced household budget and even difficulties with satisfying the very basic needs, like paying for utilities. Among the reasons that cause such a situation, might be a lack of willingness to control one's behaviour and to avoid the related inconvenience, but first and probably the most significant factor is a lack of knowledge and information needed to support rational behaviour. From this point of view, any additional information that may help to increase financial awareness should stimulate rationality in managing households' financial resources.

Despite numerous research studies and theories developed, the decisionmaking process related to the control of household budgets still contains significant gaps and remains too complicated to be efficient. In 2011, M. A. H. Dempster and E. A. Medova stated in their article, 'Advances in behavioural finance $<\ldots>$ have not yet delivered a practical solution' (Dempster, Medova 2011). They support this statement by citing Paul Samuelson's keynote address at a conference on life-cycle investment: 'Is personal finance an exact science?' with the immediate answer 'flat no'. In his words, 'It is a domain full of ordinary common sense. Alas, common sense is not the same thing as good sense. Good sense in these esoteric puzzles is hard to come by' (Barber, Odean 2005; Samuelson 2007). The above discussed problems, which the consumer is forced to solve many times a day, is very much in line with and supports the statements of Paul Samuelson, Herbert Simon as well as the conclusions of many other authors of the latest publications. The decision-making criteria that were used are mainly qualitative, subjective and do not provide information needed to make clear decisions based on measurable quantitative indicators. Attempts to introduce units called 'utils' by Jeremy Bentham (1789), as a utility measure, did not 
change much as the character of the decision-making criteria itself remained unchanged (The Human Condition Organisation 2013).

The following can be stated while summarising the analysis of investigations and theories that form the background for household expenditure management: both economic and psychological approaches have their own advantages and are helpful in analysing various aspects of consumer behaviour. The economic-psychological approach, which combines some advantages of the two approaches mentioned previously, has emerged in the second half of $20^{\text {th }}$ century and gave start to several new theories (e.g. behavioural finance). The emergence of the latter was stimulated first of all by the need to better understand processes on a macroeconomics level, especially those related to the analysis of supply and demand in commodity and financial markets; therefore, processes have been mainly analysed from this point of view. A high priority was never given to the analysis of financial decision-making from the consumer's point of view; therefore, the volume of such investigations remains at a much lower level when compared to the analysis of various consumption aspects from the goods and services seller's point of view. This might be one of the reasons causing poor budgetary performance in many households.

The performed historical analysis has highlighted several motivation contexts for research within consumer behaviour, which differ by nature:

- Firstly, the most significant analysis of consumer behaviour is as of a factor that determines market demand. Both theory and practical activities within (e.g. marketing) are predominantly based on data derived from consumer behaviour.

- Secondly, analysis of processes on a macroeconomics level to produce the data needed for national accounts, evaluation of performance of a country's economy in general and in making decisions regarding whether or not interference from the side of government or central bank is needed to change the situation.

- Thirdly, analysis of households (individuals) and their financial performance.

The first two contexts of analysis have so far clearly dominated in the research of consumer behaviour while the third seems to be underestimated even though its significance is huge not only for every single household and its economic partners (e.g. commercial banks, leasing companies, etc.), but also for the economic performance of entire country. The high share of financially poorly performing households might be due to shortcomings in theoretical support for consumers who need to act in a very dynamic and permanently changing environment. Therefore, the 2015 Nobel Prize in economics awarded to Angus Deaton (The Official Website of the Nobel Prize 2015) for his research in this specific context could be interpreted as recognition of its high importance. 


\subsubsection{Role of Consumer Behavior in Household Financial Decisions}

\subsubsection{Patterns and Types of Consumer Behaviour and Decision- Making Motivational Mechanisms}

A traditional social class approach (Smith 1964) has been used for many years by numerous researchers and specialists to characterise and understand the consumer behaviour of households, which differ by income, habits and position in society. Classification of consumer types by social classes comprise 6 classes:

Upper-upper $(0.5 \%)$. These are the old established families in a community. Their goals can be characterised in the following terms: gracious living, family reputation and community responsibility. The individual either has to be born into this group or can achieve it through a successful career.

Lower-upper (2\%). These are the newly arrived as top executives of large corporations, entrepreneurs of large businesses, successful doctors and lawyers. Their family goals are a blend of the upper-upper (gracious living) and the upper-middle (drive for success).

Upper-middle (10\%). These are mostly the professionals such as the employees of organizations, the junior executives and etc. The goal here is mainly a successful career. Sociability and wide interests are characteristic of this group.

Lower-middle (35\%). This is the top of the average class: the white collar, salaried office workers, the small businessmen and the office workers. The goal here is respectability. They like a nice home, nice clothes and a good neighbourhood.

Upper-lower (40\%). This is the ordinary working people who is a wage earner and skilled worker. The orientation here was found to be toward enjoying life. They want to be modern.

Lower-lower $(12 \%)$. This is the unskilled labor group, the sporadically unemployed. This group is characterised by apathy, fatalism and the idea of 'getting your kicks when you can' (Smith 1964).

A number of different approaches have been adopted in the study of decision-making, drawing on differing traditions of psychology. The differing psychological approaches have been applied to research in the individual consumption area (Bray 2008). Writers suggest different typological classifications of these researches with five major approaches emerging. Each of the approaches posit alternate models of man and emphasize the need to examine quite different variables (Foxall 1990):

Economic Man. Early research regarded man as entirely rational and selfinterested, who makes decisions based upon the ability to maximise utility whilst expending the minimum effort. While work in this area began around 300 
years ago (Richarme 2005), the term 'economic man' (or even Homo economicus [Persky 1995]) was first used in the late 19th century (Persky 1995) by critics of John Stuart Mill's work on political economy at the start of more sustained research in the area. In order to behave rationally in the economic sense, as this approach suggests, a consumer would have to be aware of all the available consumption options, be capable of correctly rating each alternative and be available to select the optimum course of action (Schiffman, Kanuk 2007). These steps are no longer seen as a realistic account of human decision-making, as consumers rarely have adequate information, motivation or time to make such a 'perfect' decision and are often acted upon by less rational influences such as social relationships and values (Simon 1997). Furthermore, individuals are often described as seeking satisfactory rather than optimum choices, as it is highlighted in Herbert Simons' satisficing theory (Simon 1997), or Kahneman and Tversky's prospect theory (Kahneman, Tversky 1979), which embrace bounded rationality (Simon 1991; Bray 2008).

Psychodynamic. The psychodynamic tradition within psychology is widely attributed to the work of Sigmund Freud (Stewart 1994). This view posits that behaviour is subjected to biological influence through 'instinctive forces' or 'drives', which act outside of conscious thought (Arnold et al. 2010). The key tenet of the psychodynamic approach is that behaviour is determined by biological drives, rather than individual cognition or environmental stimuli (Howard, Sheth 1969; Bray 2008).

Behaviourist. Essentially behaviourism is a family of philosophies stating that behaviour is explained by external events and that all things that organisms do, including actions, thoughts and feelings, can be regarded as behaviours. The causation of behaviour is attributed to factors external to the individual (Bray 2008).

Cognitive. In stark contrast to the foundations of classical behaviouralism, the cognitive approach ascribes observed action (behaviour) to intrapersonal cognition. The individual is viewed as an 'information processor' (Ribeaux, Poppleton 1978). This intrapersonal causation clearly challenges the explicative power of environmental variables suggested in behavioural approaches; however, an influential role of the environment and social experience is acknowledged with consumers actively seeking and receiving environmental and social stimuli as informational inputs aiding internal decision-making (Stewart 1994).

Humanistic. The humanistic approach uses behaviour motives, which are beyond those, which actually make ground for Economic Man's behaviour based on purely egoistic motives.

Yet another classification of various consumer types has been recently presented by Euromonitor International (2015): 
Undaunted Striver. Looks for new and innovative products, wants to dominate in society and be exceptional. Likes luxury and exclusive things.

Impulsive Spender. Makes buying decisions according to emotions, is advertising sensitive. Enjoys comfort, brands, beautiful packages, etc.

Conservative Homebody. Pays attention to well-known products, rarely buys novelties. Does not want to dominate in society.

Aspiring Struggler. Searches for something that could make him unique and idiosyncratic. Likes prestige and well-known brands.

Independent Skeptic. Makes buying decisions according to himself, is not advertising sensitive. Likes high quality purchases. Before buying, analyses all product features.

Secure Traditionalist. Buys tested items, does not pay attention to new products. Likes stability and traditions.

Balanced Optimist. Makes buying decisions rationally, likes tested items, but does not exclude innovations.

In addition, a number of new consumption types have emerged recently, among them sustainable consumption - ways of consumption that reduce environmental stress and meet the basic needs of humanity. Areas: mobility, housing, clothing, nutrition. Characteristics: eco-efficiency and changing lifestyle of humans in order to reduce the emission of $\mathrm{CO}_{2}$ (Hertwich et al. 2015), green consumption - a concept that ascribes to consumers the responsibility or coresponsibility for addressing environmental problems through adoption of environmentally friendly behaviours, such as the use of organic products, clean and renewable energy and the research of goods produced by companies with zero, or almost, zero impact (Connoly, Prothero 2008; Elliott 2013), smart consumption - consumption that creates a prosperous world while using fewer resources or buying something with a view to sustainable benefits (Brohmann Quack 2015), connected consumers - evolving consumer behaviour in light of smartphones, tablets and PC growth as new channels (such as e-stores) and new devices are more and more important for consuming decisions. Consumers are modern deal seekers, IT devices are shoppers' arsenal, and they usually shop online (Oracle 2012).

It should be noted that behaviour within any of the mentioned social classes or other consumer groups is not always homogeneous. Investigations on consumer behaviour consider a variety of factors that influence purchase decisions and acknowledge a range of typical actions that precede it. In 1968, Engel, Blackwell and Kollat developed a model of the consumer buying decision process (or consumption decision making tree) and divided it into five steps (Fig. 1.13). These steps commonly include: need recognition, information 
search, evaluation of alternatives, the building of purchase intention, the act of purchasing, consumption and finally disposal (Bray 2008), and all of them are influenced by the marketing system (advertising and various sales components). The expanded consumption decision making tree is shown in Appendix A.

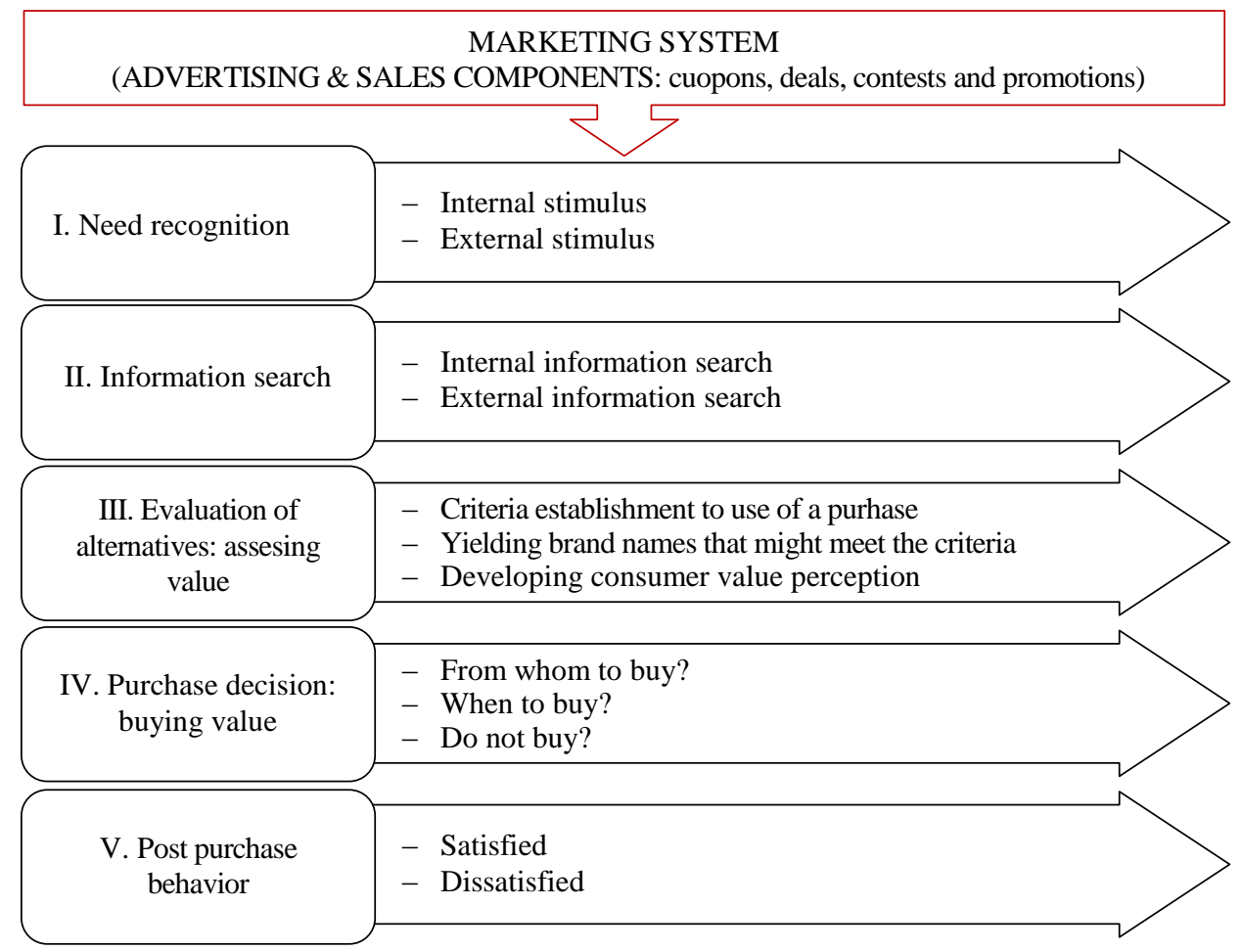

Fig. 1.13. Consumer decision making process (created by author according to Engel et al. 1968; Grewal et al. 2003)

As noted by Jeff Bray (2008), this more complete view of consumer behaviour has evolved through a number of discernable stages over the past century in light of new research methodologies and paradigmatic approaches being adopted. Consumers are typically not completely rational, nor consistent, nor even aware of the various elements that enter into their decision-making. Consumption patterns seem to become very mixed as the world is becoming more and more virtual, especially with emerging new technologies and diminishing traditional boundaries for spreading ideas across society. Consumers no longer strictly follow a certain consumer pattern specific for their social class or group, tend to ignore limits set by available resources, and as a result, very often face budget balancing problems. 
The social class approach presumes that consumer behaviour is first of all subject to available resources and is generally restricted to and falls under the limits as described in the portrait of the economic man presented in the previous typological classification. At least three types of consumer patterns (psychodynamic, behaviourist and humanistic) included in the previous classification do not necessarily follow this principle, which means that budget constraint is not a prevailing factor in consumer decision-making. Newly emerged patterns are also quite liberal in this sense, which means that a number of those who follow certain consumer ideas without paying due attention to the availability of resources might increase the group of individuals who will face financial resource management problems.

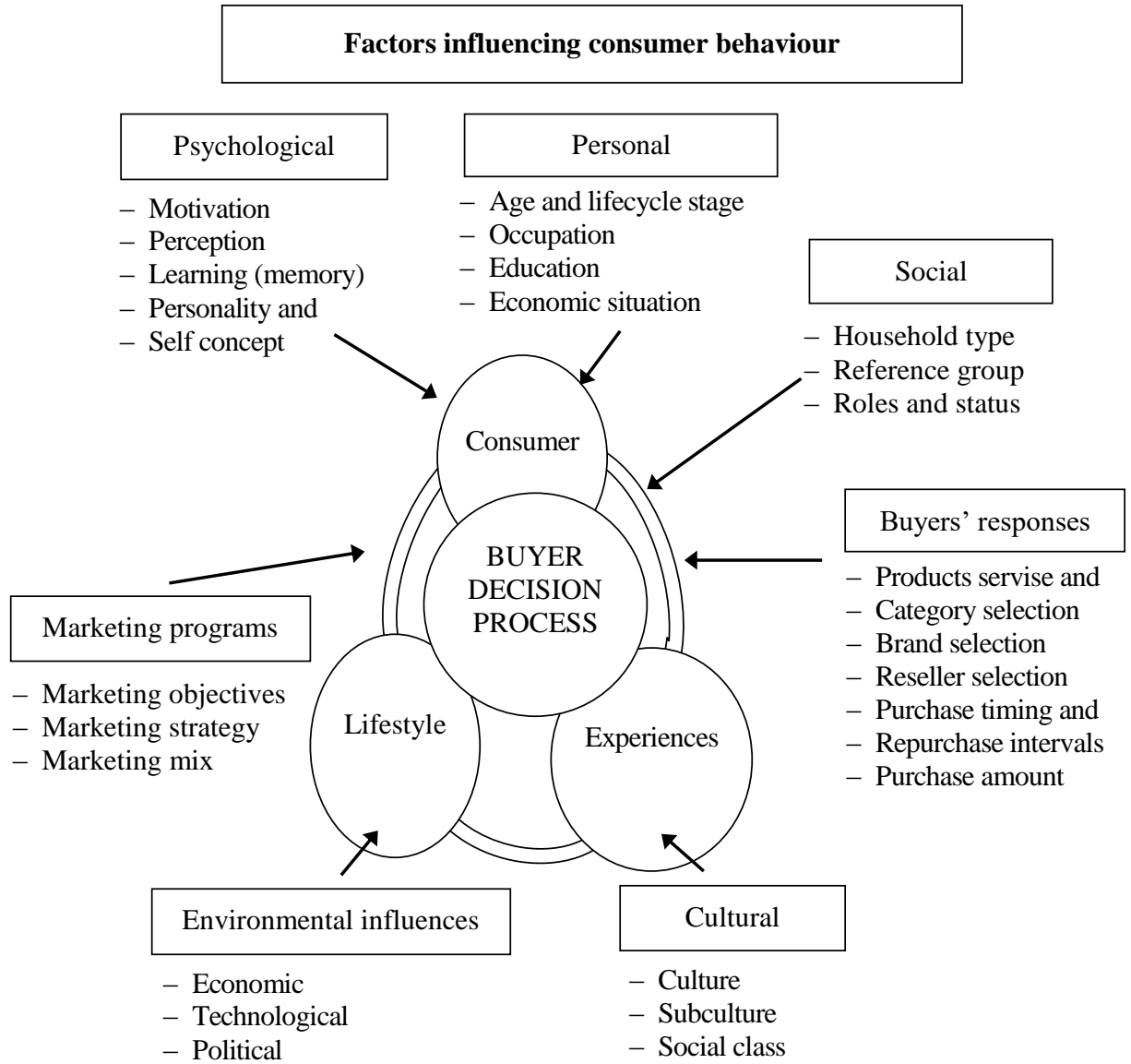

Fig. 1.14. Main factors that influence consumer behaviour (Consumer Voice 2012) 


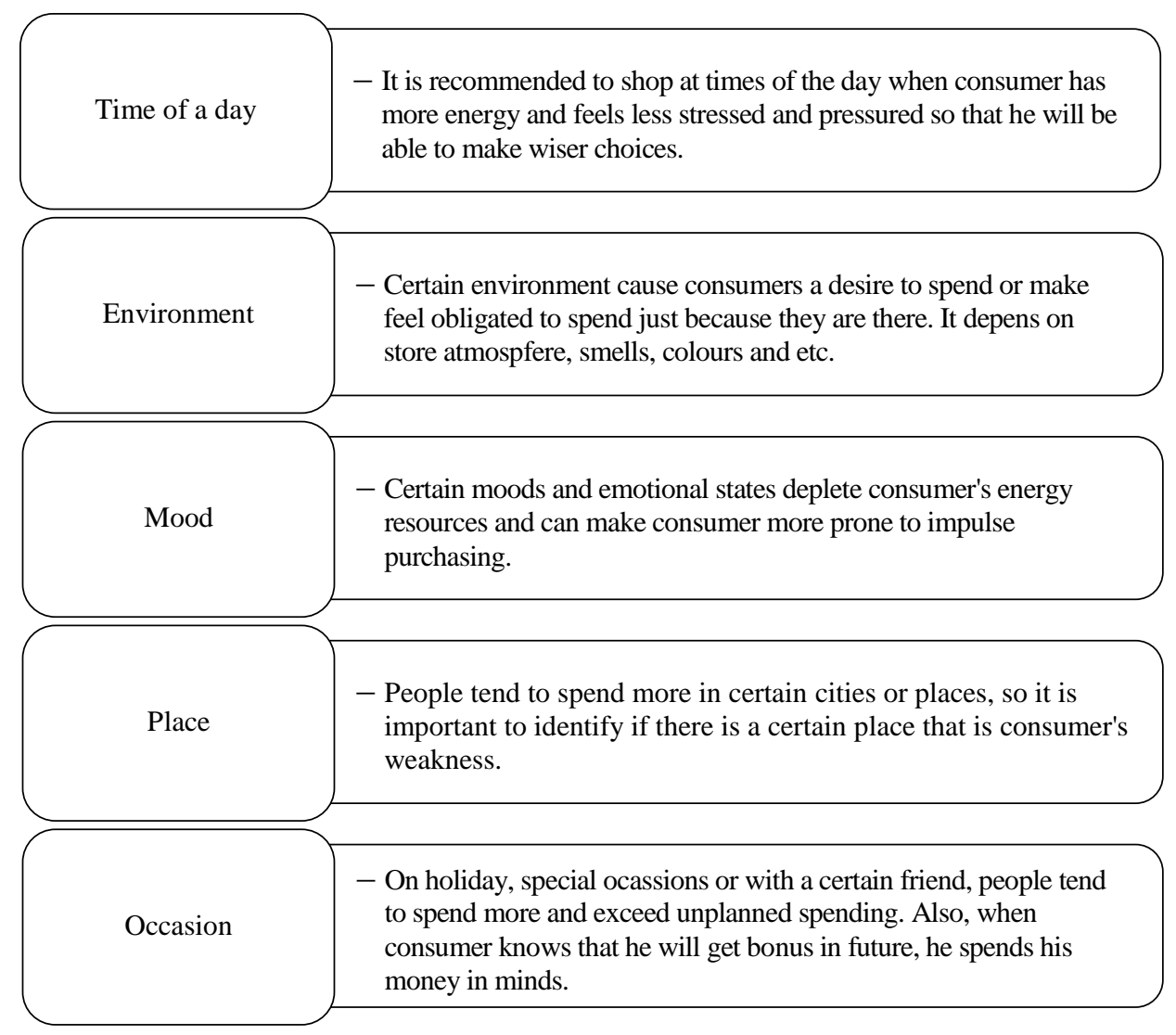

Fig. 1.15. Description of TEMPO method (created by author according to Credit Counselling Society 2016)

These factors lead to impulsive spending. In order to minimize the influence of them, specialists recommend using the TEMPO rule (Fig. 1.15).

This method helps consumers identify the main factors that affect their impulsive spending and control them. It is oriented towards limiting the opportunities to spend by avoiding some special environments, by identifying the moods that affect spending behaviour (e.g. happy, sad, hungry, tired, distracted) and finding ways not to shop during such moods. The method totally relies on psychological measures and uses no economic controls.

All the above said, illustrates how complex and difficult consumer decision-making is to control. Obviously, no rational decisions can be made without using criteria, which enable objective, preferably quantitative evaluation of the above mentioned versatile factors affecting them. Therefore, the existing 
household financial management methods and models have to be evaluated taking this into account before they are applied as a tool for managing household resources.

\subsubsection{Rationality Problem in Consumer Behaviour}

The starting point of the traditional approach concerning consumer behaviour is represented by the postulate of rationality. Thus, considering that goods offered on the market generate utility, by virtue of this postulate it is estimated that, in the consumption act, the person is capable of solving simultaneously two problems, namely: one of decision, with regard to the choice among several consumer goods that can respond to his or her needs and one of maximising the satisfaction felt after the undertaken choice. Within this context, rational consumer equilibrium is built forward, taking into account, on one hand, the needs he or she feels at a certain moment, and on the other hand, the budget constraints imposed both by the prices of those goods and by the income that is effectively at his or her disposal (Gheorghiu 2011).

Irrationality is often perceived as opposite to rationality. These terms are derived from Latin origin words: irrationality (latin: irrationalis - irrational, imprudent) and rationality (latin: rationalis - rational, clever). The word rational identifies the individual's ability to think on the basis of mind, targeted action and economic context, and the word is usually associated with the ability to assess the activities of the circumstances and consequences of the effective use of resources. This efficiency is based on the decision-making rules that maximise the benefits sought. Irrationality and the like should be considered unwise or thoughtless actions of consumers.

An alternative approach to the traditional one concerning rational consumer behaviour is offered by the new theory of 'characteristics', starting from the prerequisite that the utility of an economic good is generated by the characteristics or properties it has within the market. Consequently, consumer behaviour is the result of choosing the maximisation of satisfaction in terms of the quantity of characteristics it has; goods will be differentiated according to the combination of characteristics they have, and the demand for a certain good will be derived from the demand for its characteristics (Gheorghiu 2011). A first version of the model of characteristics is elaborated by Hendrik S. Houthakker, who introduces a new function of utility which, together with the traditional variables related to the physical quantities of goods that the consumer wants to purchase also includes their qualities, as variables that are separated from the first ones (Houthakker 1953). In fact, Houthakker starts from the idea that a good can be described by two different variables - the physical quantity and its quality. Accordingly, it can be motivated that the goods, which possess different character- 
istics can be treated as one and the same good, but having a variable quality. Consumers could choose explicitly the quality of a good, and by their choice, the determination of its sale price would be possible. The second version of the model of characteristics, and also the most evolved one, is developed by Kelvin Lancaster, by initiating the suggestion of constructing a new demand theory based on the idea according to which 'goods possess or give rise to multiple characteristics in fixed proportions and that it is these characteristics, not goods themselves, on which the consumer's preferences are exercised'. Accordingly, a good will have more than one characteristic, and some characteristics will be shared by several goods (Gheorghiu 2011).

In principle, the hypotheses from which Lancaster starts in the construction of his variation concerning consumer theory can be presented in a synthetic manner as follows. Firstly, the characteristics represent objective and intrinsic properties of consumption activities. Secondly, doubling the production of goods involves doubling the characteristics - which supposes a linear homogeneity. Thirdly, the characteristics possessed by goods or by their combination can be presented under the form of some vectors of characteristics arranged by the consumers. Fourthly, not the goods themselves, but their characteristics generate utility. Also, a combination among several goods can possess characteristics that are different from those which belong to one of the respective goods treated separately. Accordingly, the psychological effects, such as the consumer's relative interest in different characteristics, can be assumed to be felt in the preferential ordering manner of the vectors of characteristics and not in the relation between goods and characteristics. The problem of maximising the utility, as presented by Lancaster, is similar to the traditional analysis. As a matter of fact, if the number of goods and of the characteristics are equal, the traditional approach and the method suggested by Lancaster only lead to the retrieval of the same solution, but in all the other cases, important differences appear. On one hand, the maximisation of utility can be obtained by using some non-linear programming techniques, unlike the simple method of optimisation used in the traditional model. On the other hand, a sole consumer cannot be considered as representative, so that the aggregated behaviour of the bearers of demand within the market can be determined by the multiplication of the representative consumer's demand with the number of present consumers. Consequently, in deriving the aggregated demand for a certain good, both the distribution of preferences for its characteristics and the distribution of consumers' income must be considered. From the theoretical point of view, this approach offers certain advantages, such as the more concrete explanation of the fact that a consumer can be indifferent between two goods, which, although they seem quite different, can be considered to possess similar sets of characteristics. Moreover, the Lancastrian hypothesis concerning consumer behaviour allows the explanation of introducing some 
new products or the disappearance of some old ones and also the motivation of distinction in consumption between the commutable goods and complementary (Gheorghiu 2011).

Results of the research performed in Chapter 1 enables formulation of the following conclusions.

\subsection{Conclusions of Chapter 1 and Formulating Tasks for the Dissertation}

1. The volume of household-related monetary flow in Lithuania makes up approximately $2 / 3$ of the GDP while the total revenue of the retail banking segment is only $1-2 \%$ of that amount. Besides, the quality of money flow in the latter segment is such that it results in a relatively high level of non-performing loans. Both limited turnover and the imperfect quality of the loan portfolio have a negative effect on the performance of commercial banks.

2. Research indicates that between $30 \%$ and $40 \%$ of households in Lithuania experience difficulties with maintaining balanced budgets. The share of unbalanced budgets appears to be similar in all household segments irrelevant of income level, suggesting that income is not the prevailing factor in keeping budgets balanced, and the budgetary performance is rather subject more to consumer behaviour than to income.

3. Same or similar problems are currently urgent not only in Lithuania, but also in other countries, including those with advanced economies, (e.g. Spain, Portugal, Iceland, Greece, Cyprus, and others).

4. A vast majority of economic theories ignore or skip this problem by assuming that the consumer is always rational and makes the right decisions according to his or her experience, common sense and clear priorities and acts within the limits of his or her budget.

5. Historical analysis highlights several motivation contexts for research within household economics and consumer behaviour: a) most widely research has been performed to analyse consumption as a factor, which determines market demand. Both theory and practical activities within marketing are predominantly based on data derived from consumer behaviour; $b$ ) analysis with the aim of producing data needed for national accounts, evaluation of performance of a country's economy in general and decision-making whether or not 
interference from the government or central bank is needed to change the situation; c) analysis of financial and economic performance of households (individuals). First, two contexts of analysis have so far clearly dominated in the research while the third seemed to be underestimated even though its significance is huge not only for separate households, their long-term economic partners, such as commercial banks, leasing companies, etc., but also for the performance of entire countries.

6. The high share of poorly financially performing households may result from weak theoretical support within consumer decisionmaking, which appears to be extremely complex and is strongly affected by dynamic and permanently changing environment.

Based on the literature survey and performed comparative analysis of household-related monetary flows in product and retail banking markets and their management problems, the following objectives have been defined for further research:

1. Perform critical analysis of theoretical concepts and practical tools related to the management of monetary flows intended for consumption.

2. Develop a formalized, quantitative criteria-based approach to the management of household consumption expenditure, applicable to elementary purchases.

3. Investigate and quantitatively evaluate the influence of consumption and financial behaviour on the borrower performance of bank clients.

4. Develop a personal consumption expenditure guidance system, joining households and commercial banks, and a method for the quantitative evaluation of its economic efficiency. 



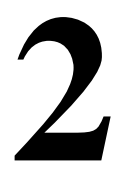

\section{Formalized Approach to Consumption Expenditure Management of Households: Principles and Practical Application}

This Chapter analyses the methods and tools available for personal consumption expenditure management on the elementary purchases level, their efficiency and shortcomings. Based on the results obtained, the alternative management principles and a method for budget planning and control in households were developed and supported by theoretical justification. The principles, which are based on value decomposition of goods and services, enable full or partial elimination of the effect of subjective factors on consumption-related financial decisions in households by formalizing decision-making procedures and introducing quantitative criteria for their evaluation and comparison. The principles primarily target the management of expenditures on the elementary purchase level. Several case-studies within micro and macroeconomics segments have been conducted to test them.

Results of investigations in Chapter 2 are published in two author's publications (Taujanskaitè, Milčius 2015; Taujanskaitè et al. 2015). 


\subsection{Analysis of Models Used for Household Financial Flows Management}

Individuals often face the problem of managing their assets in a way that ensures that all their liabilities are met and personal financial goals achieved. This domain is known as asset and liability management (ALM). It has seen tremendous recognition and growth in research as well as in practice in the last couple of years. A wide-ranging overview on this research is presented in the book by Ziemba and Mulvey (1998). The primary application areas of ALM are pension plans, insurance companies, banks, university endowments and individual investors (Hocht et al.2008).

The most popular models for asset-liability management are described below.

Individual Asset-Liability Management model (iALM) (M. A. H. Dempster and E. A. Medova, Cambridge University, 2011).

The model is intended for life-long financial decision-making in households and, particularly, to help develop the retirement plans. In framing the life-cycle consumption investment problem, the authors assert two principles: a) individual wealth is measured by sustainable spending over a household's life time; and b)individual risk attitude at any point in time is a reflection of existing and foreseen liabilities together with a subjective view of desirable personal future consumption. Recognition of the enormous complexity of this task - creating an individual life-cycle financial plan under the uncertainties of market and life events - dictates a dynamic solution, which is appropriate to changing individual behaviour and circumstances and which permits a 'what if' analysis of alternative scenarios. The model employs Monte Carlo simulation, discrete or continuous dynamic programing; and dynamic stochastic programming (DSP).

\section{Dynamic Model for Individual Asset Liability Management}

It is a meta-model based on the principles of dynamic stochastic programming and is used as a support tool, which allows interactive use with successive modification of individual preferences and data inputs as required. The model offers more than one financial plan to the households for consideration based on their subjective opinions regarding future life events. The name of the meta-model and the corresponding system - individual asset liability management $(i \mathrm{ALM})$ - indicates that the modelling methodology came from the operations research topic decision-making under uncertainty. In the system developed, the principal ideas (to help individuals with long-term 
financial planning decisions) are brought together from the behavioural finance, classical finance and the stochastic optimisation theories. The household financial planning problem is a dynamic multistage stochastic optimisation problem in discrete time. The iALM meta-model consists of many individual sub-models with a logical structure. The process of generating the problem instance and solution is comprised of three stages: a) the forward simulation of stochastic data processes; b) solution of stochastic optimisation problem; and c) analysis of the optimal decisions.

The interactive use of the system starts at Stage 3 when a 'user' either accepts the current financial plan generated or chooses to explore alternatives. A new paradigm - a move from the static solution of a single problem to an interactive process for the identification of the solution most suitable to the user - is achieved. The first task is to simulate stochastic asset returns and liabilities to support the full cash flow modelling in $i$ ALM. Appropriate to such a dynamic stochastic programming model, scenarios for these entities must be simulated in the form of a scenario tree so that major forward portfolio rebalances face alternative asset/liability scenarios. Scenario generation steps:

Asset return and inflation simulation. The types of stochastic processes suitable for the simulation of the asset classes used in $i \mathrm{ALM}$ are geometric Brownian motion, Ornstein - Uhlenbeck process and geometric Ornstein - Uhlenbeck process.

Event simulation. The heads of a household consist of at least one or two persons. In their lifetime, the major random events are death and serious illness requiring long-term care.

Liability simulation. Liabilities run for a certain number of years unless a household death event occurs beforehand. Although existing loan and mortgage repayment liabilities are fixed in currency value at inception, in general, liabilities are indexed for inflation and all forward individual liabilities may have an additional fixed per annual growth rate.

Optimisation. The formulation of the objective for optimisation presents the most challenging problem, and it has been overcome by adopting some critical ideas from behavioural finance. Rationality is best served by adopting broad frames rather than concentrating on changes. In order to optimise decisions related to the management of personal finances, the objective formulating of the $i$ ALM problem uses the notion of the value function and combines two types of framing: narrow framing - with respect to the ability to achieve the desired/acceptable spending level on any specific goal (e.g. specified annual living cost in any particular future life). This translates 
into the objective of maximising the real goal spending within the range of minimum, acceptable and desirable values; and a Broad framing - with respect to the satisfaction gained from accumulating wealth over a lifetime while making decisions regarding consumption and covering liabilities, while minimising the possible risk. The wealth is seen as generating 'sustainable spending'. Formally, this translates into the objective of maximising real spending on all goals that the financial portfolio can sustain throughout the household's lifetime.

Objective. The utility function for each individual goal is a piecewise linear function, which is constructed for a range of spending between acceptable and desirable values, subjected to existing and foreseen liabilities, and a minimum of required spending. The shape of an individual utility function in each year defines the household's attitude to risk in that year, resulting in a time - varying forward attitude to risk appropriate to goals and life circumstances. The overall objective of the iALM optimisation is to maximise the expected utility of lifetime consumption, taking into account the total tax payments and excess borrowing.

Constraints. The objectives for investment are dependent on many factors, such as personal priorities, aspirations, human capital, family status, etc. In this context, iALM may be interpreted as performing constrained optimum resource allocation over an individual household's lifetime. The overall optimisation problem may become infeasible when liabilities and/or the required level of consumption exceed the possible returns from the household assets and other sources of income.

The difference between inflows and outflows gives the net increase in a household's financial wealth in a given year. The risk characteristics of the evolution of optimal portfolios depend on asset return volatilities, their correlations and the risk management constraints of the portfolio models. These constraints, set according to individual household preferences, impose a tolerable annual drawdown of the portfolio in each of these scenarios over the household's lifetime.

Hybrid Model for Optimal Decisions within Personal Finance and Retirement (Agnieszka Karolina Konicz, Technical University of Denmark, 2012)

The model covers two cases of application: Case A deals with optimal investment, consumption and life insurance; and Case B with optimal investment with optimal annuities. The model uses stochastic optimal control for explicit solutions and stochastic (linear) programming. 
Financial Planning for Young Households: Multi-stage Stochastic Programming Model (Anne Marie B. Pedersen, Alex Weissensteiner, Rolf Poulsen, University of Copenhagen, 2013)

Analysing the financial planning problems of young households whose main decisions regard the ability to finance the purchase of a house (liabilities) and allocation of investments into pension savings schemes (assets). The problems are solved using a multi-stage stochastic programming model where the uncertainty is described by a scenario tree generated from a vector autoregressive process for equity returns and interest rate evolution. Strong evidence is found of the importance of taking into account the multi-stage nature of the problem as well as the need to consider the asset and liability sides jointly.

Personal Asset Allocation Model (Andrea Consiglio, Flavio Cocco, Stavros A. Zenios, HERMES Center of Excellence on Computational Finance \& Economics, School of Economics and Management, University of Cyprus, University of Palerm, 2002)

The system of Personal Financial Tools (PFT) provides support for each one of the goals facing a typical family, thus extending the work of Financial Engines, but it does so by segmenting the family's planning problem into distinct sub-goals. The user specifies the financial planning problem by indicating the time horizon of the project, the target goal, and the current asset availability. This information is sufficient in calculating the target return that the individual expects. The system of PFT will then assist the user in structuring an asset allocation consistent with this target return and the appetite towards risk revealed by answering an on-line questionnaire. PFT provides three interactive models for each user: a) Personal asset allocation; b) Personal rating, and c) Personal risk analyser. These three tools form part of an integrated interactive system that allows users to carry out game-of-life simulations, addressing both strategic and tactical issues. The personal risk analyser provides a control module to ensure that the developed strategy and its execution will meet the targets.

Considering everything, all mentioned and analysed models could be classified as it is shown in Figure 2.1. and in Appendix B.

The analysed theoretical models applicable to household budget management are rather complicated and difficult to use by households. Besides, they are used to plan allocation of financial resources for a certain period of life-cycle and in some cases, they cover all the life of an individual. They are not applicable for planning consumption related to every day spending and detailed to the level, covering every elementary purchase. 
Multi-stage stochastic linear programming and dynamic programming methods

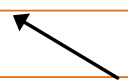

A. K. Konicz, Technical University of Denmark, 2012

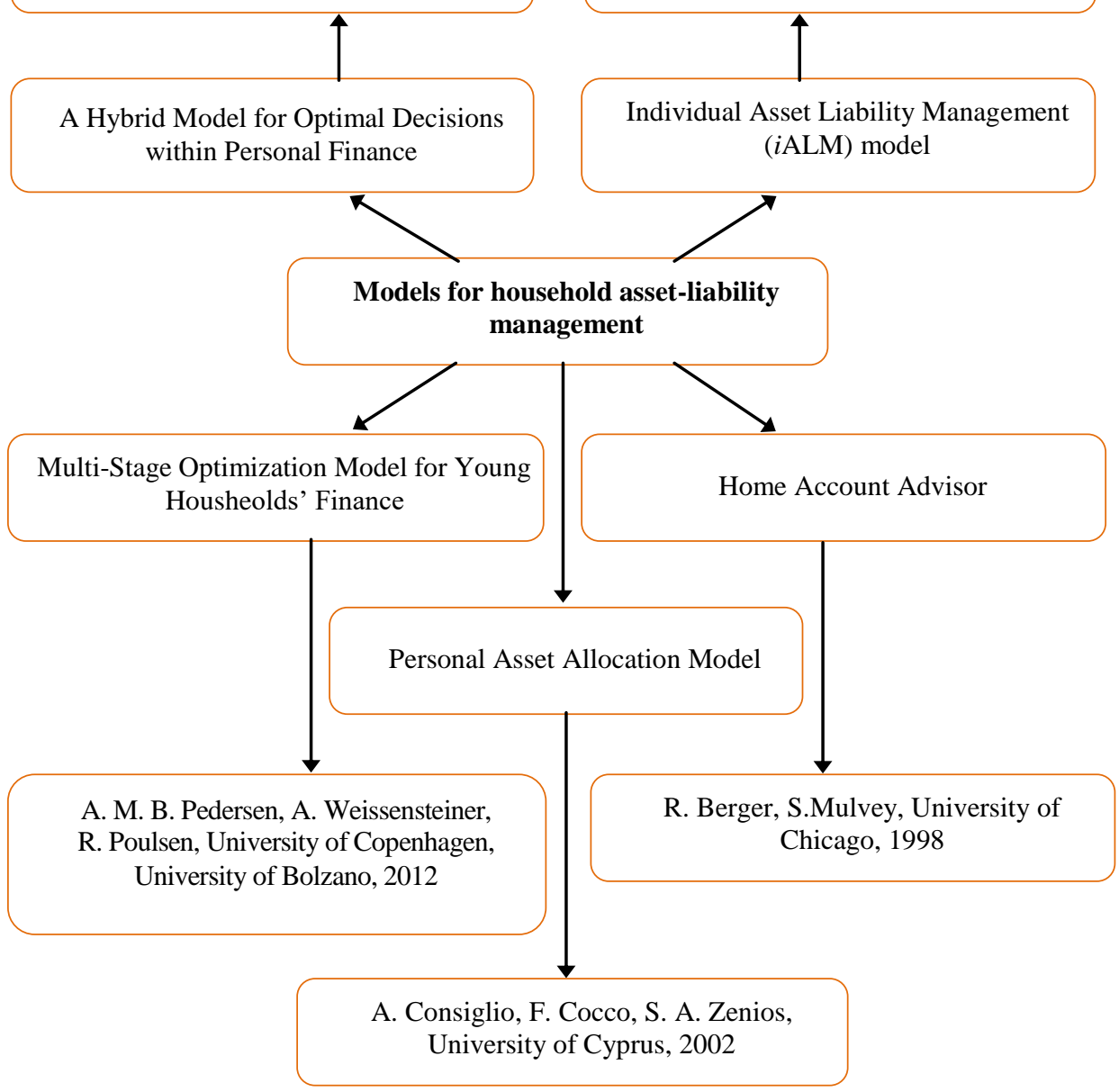

Fig. 2.1. Most popular models for individual's asset-liability management (source: author)

Tools developed for practical use by households to manage financial resources, that can be found in the market, are shown in Table 2.1. 
Table 2.1. The most popular budgeting tools for households (created by author according to Sharf 2016; Corpuz 2015; Henry 2014; Crary 2012; Herdrich 2008)

\begin{tabular}{|c|c|}
\hline \multicolumn{2}{|c|}{ Practical Tools for Household Finance Management } \\
\hline 1. You Need a Budget (YNAB) & 43. Mvelopes \\
\hline 2. Mint & 44. Money Tracker \\
\hline 3. Buxfer & 45. Bank Tree \\
\hline 4. Geezeo & 46. Neo Budget \\
\hline 5. BudgetPulse & 47. Money Weil \\
\hline 6. Gnu Cash & 48. Simple Budgeting \\
\hline 7. Budget Simple & 49. Budget Planner \\
\hline 8. Wallet & 50. Money Plus Deluxe \\
\hline 9. Spendbook & 51. Mano finansai \\
\hline 10. Home Budget with Sync & 52. Daily Expenses \\
\hline 11. Level Money & 53. Money Book \\
\hline 12. BUDGT & 54. Spendle \\
\hline 13. Spendee & 55. Manilla \\
\hline 14. Expensify & 56. Check \\
\hline 15. MoneyDance & 57. Expensify \\
\hline 16. Moneystrands & 58. Level Money \\
\hline 17. Pocketsmith & 59. BankPlus Persona Mobile \\
\hline 18. Yodlee & 60. Splash Money \\
\hline 19. Consur & 61. Personal Finance Manager Lite \\
\hline 20. BillGuard & 62. Easy Finance Personal \\
\hline 21. Dollarbird & 63. One Money \\
\hline 22. Fudget & 64. Personal Budgeter \\
\hline 23. Goodbudget & 65. Personal Wallet Manager \\
\hline 24. LearnVest & 66. Personal Accounting \\
\hline 25. Level Money & 67. Personal Finance Planner \\
\hline 26. Penny & 68. Personal Financial Record \\
\hline 27. Personal Capital & 69. Personal Finance Report \\
\hline 28. Wallaby & 70. Personal Finance Helper \\
\hline 29. Money Manager Ex & 71. Star Money 8.0 \\
\hline 30. Simple Accounting & 72. Money Me \\
\hline 31. My Micro Balance & 73. Expense Online \\
\hline 32. Money Dance & 74. Armory 0.87 \\
\hline 33. Butas & 75. Ace Money \\
\hline 34. Namų Buhalteris & 76. Kur dingo pinigai? \\
\hline 35. Quicken Deluxe 2014 & 77. Easy Money \\
\hline 36. Expense IQ & 78. Microsoft Money \\
\hline 37. Expense Notes & 79. Home Bank \\
\hline 38. Good Budget & 80. Bank Tree Personal \\
\hline 39. Money Dash Board & 81. Simple Home Money Management \\
\hline 40. Love Money & 82. Rich or Poor \\
\hline 41. Clear CheckBook & 83. Budget Express \\
\hline 42. My Spending Plan & 84. MS Dynamics nav. \\
\hline
\end{tabular}


End of Table 2.1

\section{Practical Tools for Household Finance Management}

85. Budget Pulse

86. Personal Finance 101

87. General Financing

88. Mokos.lt

89. Budget Express

90. Simple Home Money Manager

91. Personal Finance Hero

92. Piggy Bobb

93. CCash
94. Mano piniginè

95. Financisto

96. Inex

97. Wally Me

98. Hamnd Wallet Expense Manager

99. Bill guard

100.Fautor Tigris

101. The Pocket Financial Planner 102.Toshl

All the above tools are the most popular special software for budget planning, which is a long process generally comprised of steps displayed in Fig. 2.2. A household can organize its cash flow, expenses and usually bank accounts in one place. Charts and graphs visualize monetary flows every month, and statistics show data from month-to-month. This information enables a person to track his or her progress, discover where he or she can make savings and improve the money management process.

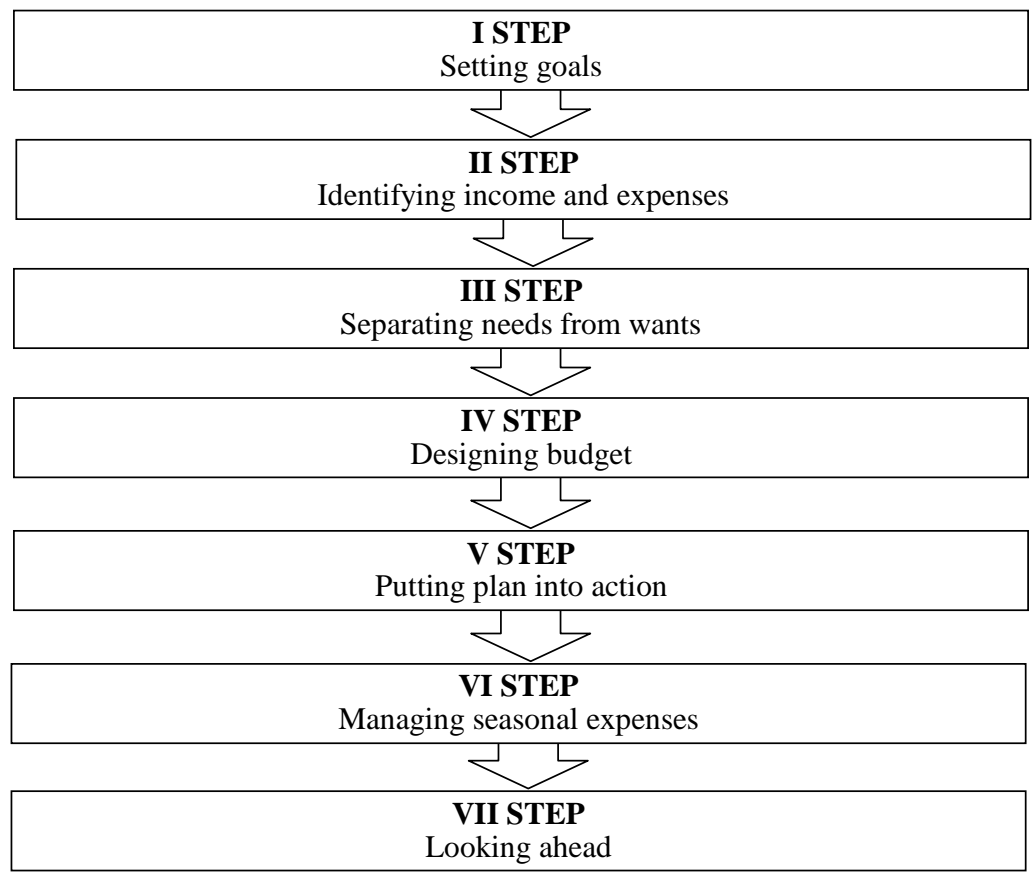

Fig. 2.2. Main budget building steps (created by author according to Credit Counselling Society 2016) 
The main shortcoming of the observed tools is that they are only used to register expenditure and follow-up the cash flow, but do not provide the possibility to optimise the allocation of funds on elementary purchase level. The procedures used do not include any formal analysis and evaluation of the utility.

The analysed models are not applicable to asset allocation and funds management. The other group of models is dedicated for this specific purpose: Prospero Asset Management Software (Sage 2016), Personal Capital, Quicken, Betterment, Scottrade, Tradeking, TD Ameritrade, E*Trade, Capital One ShareBuilder and Acorns (Rose 2016). Yet another group of programmes, like Ready for Zero and Credit Sesame, are debt reduction software. Credit Karma is a credit monitoring software tool and Turbo Tax - is a tax software tool (Rose 2012) and many others.

\begin{tabular}{|c|c|c|}
\hline \multicolumn{3}{|c|}{ Models for household finance management process } \\
\hline $\begin{array}{c}\text { I. Static models for incoming } \\
\text { and outgoing financial flows } \\
\text { registration }\end{array}$ & $\begin{array}{c}\text { II. Dynamic models for } \\
\text { investment decisions } \\
\text { optimization }\end{array}$ & $\begin{array}{c}\text { III. Dynamic models for } \\
\text { asset-liabilities manage- } \\
\text { ment }\end{array}$ \\
\hline \multicolumn{3}{|c|}{ What is missing? } \\
\hline Lack of tools to manage the financial processes at the level \\
of elementary purchases \\
\hline
\end{tabular}

Fig. 2.3. The summary of household financial flows management tools

(source: author)

The analysis of practical tools developed for households (Fig. 2.3) shows that although the market is relatively full of different types of models, no instruments exist to help consumer to make rational decisions on elementary purchases level, when decision has to be made by choosing from many alternatives. Further analysis aims at developing tools, which would help to fill this gap.

\subsection{Integrated Economic-Psychological Approach to the Management of Consumption Expenditure}

The household expenditure management problem is interpreted by the economics theories as finding an optimal ratio between funds allocated for current-time consumption and the savings intended for financing various needs in the future in order to guarantee maximal aggregate life-long utility. Mathematically, the problem is usually presented in a following way: 


$$
\max \sum_{t=0}^{T} b^{t} \ln \left(c_{t}\right)
$$

subject to:

$$
k_{t+1}=A k_{t}^{a}-c_{t} \geq 0
$$

for all $t=0,1,2, \ldots, T$, where $T$ is the expected lifetime of the consumer, $c_{t}$ is consumption in period $t$, which yields utility $u\left(c_{t}\right)=\ln \left(c_{t}\right)(2.3) . b^{t}$ is a factor, which discounts future utility, $k_{t}$ is a capital in period $t$. The next period's capital $k_{t+1}$ is determined by this period's capital and current consumption:

$$
k_{t+1}=A k_{t}^{a}-c_{t},
$$

where $\mathrm{A}$ is a positive constant and $0<a<1$.

Solving the problem simultaneously for all the choice variables $c_{0}$, $c_{1}, c_{2}, \ldots, c_{T}$ and $k_{1}, k_{2}, k_{3}, \ldots, k_{T+1}$ might look complicated, but the application of the dynamic programming approach (or Bellman's equation), which makes it possible to break it apart into a sequence of smaller decisions, significantly simplifies it.

If a sequence of value functions $V_{t}(k)$, for $t=0,1,2, \ldots, T, T+1$ denotes the value of having any amount of capital $k$ at each time $t$ and the condition:

$$
V_{T+1}(k)=0
$$

is taken into account, meaning there is no utility from having capital after death, than the value of any quantity of capital at any previous time can be calculated by a backward induction using the Bellman equation. In this problem, for each $t=0,1,2, \ldots, T$, the Bellman equation is:

$$
V_{t}\left(k_{t}\right)=\max \left(\ln \left(c_{t}\right)+b V_{t+1}\left(k_{t+1}\right)\right),
$$

subject to:

$$
k_{t+1}=A k_{t}^{a}-c_{t} \geq 0 .
$$

This problem is simple compared to the previous one, as it involves only two decision variables, $c_{t}$ and $k_{t+1}$ and a one step at a time solution instead of a lifetime long solution. As current capital $k_{t}$ at time $t$ is given, the only thing needed is to choose current consumption $c_{t}$ and saving $k_{t+1}$. The value function of capital at time $(t=T-j)$ is:

$$
V_{T-j}(k)=a \sum_{i=0}^{j} a^{i} b^{i} \ln k+v_{T-j},
$$


where each $v_{T-j}$ is a constant, and the optimal amount to consume at time $(t=T-j)$ is:

$$
c_{T-j}(k)=\frac{1}{\sum_{i=0}^{j} a^{i} b^{i}} A k^{a} .
$$

Finally, it turns into $c_{T}(k)=A k^{a}(2.9)$, when the life cycle comes to the end (Sniedovich 2010; Dasgupta et al. 2006; Denardo 2003).

Therefore, an optimal distribution of funds does not seem to be complicated, and the presented economic approach, if applied, should guarantee efficient management of households' financial resources. Why do so many households, irrespective of income level, experience difficulties not only with accumulating sufficient savings but also with trying to keep their current budgets balanced?

There are several reasons. First, in the problem as presented above, the consumers' task is maximally simplified. Utility from current consumption is expressed with one single function $u\left(c_{t}\right)=\ln \left(c_{t}\right)$, as if one single financial transaction could satisfy all the needs of the period. Thus, the problem in this case relies on the aggregate utility created by the aggregate value of all goods and services purchased during that period. As real aggregate utility $u\left(c_{t}\right)$ is being composed of every single financial transaction, the consumer should repeat the above mentioned procedure every time he or she pays for goods or services, including the allocation of funds for this transaction and maximising utility from it in the context of all the rest of the needs of the period. Therefore, a simple optimisation in reality turns into a multi-objective optimisation problem, where the number of needed solutions is equal to the number of goods/services purchased during the period. Second, the decision whether or not to buy a specific good is subject to the consumer's personality, personal preferences (Freud 1904; Maslow 1954) and the features of goods to be purchased. This makes decision-making challenging because the utility of every good is complex (Lancaster 1966); therefore, the optimisation problem is not only multi-objective but also multi-attribute. Third, the economic environment where consumer decisions have to be made is very dynamic. Huge efforts and resources, which manufacturers and sellers invest in marketing, change human thinking and behaviour. This strongly affects decision-making, first of all, related to the estimation of utility, turning it into a purely psychological task, which has no or almost no relation with economic rationality. As a result, the consumer's real problem becomes very complicated, having a weak connection with economic logics and it is not surprising that budget management becomes problematic for so many households. Versatile multicriteria evaluation methods, which have been increasingly used in theoretical research and practical decisionmaking in recent years (Ginevičius, Podvezko 2007, 2008) could be applied for this purpose, but solving of the problem many times a day by using such tools would not be acceptable for the consumer from the practical point of view. 
Further analysis aims at developing a new view on evaluation of the alternative choices when satisfying households' needs and planning the related expenditure. Simultaneous application and integration of economic and psychological (Maslow hierarchy of needs theory) approaches makes it possible to retrieve a bunch of additional quantitative information on goods, which enables formalization of expenditure planning and management in households and provides consumers with new possibilities compared to the currently used models.

\subsection{Value Decomposition. Theortical Justification}

The aggregate value of similar by application goods or services and the utility it generates to a specific consumer may differ a lot; therefore, consumption decisions made based on aggregate value only may not guarantee acceptable solutions. An idea behind alternative interpretation of the value of goods/services applied in this study is that value is being created and composed to guarantee the specific consumer's needs, which are complex as described in Maslow's theory of needs. Once needs are complex, the value of goods/services should also be complex and composed in a certain way to match the needs. Utility created to a specific consumer by goods/services is not subject to their aggregate value but only to certain value components contained in them. The identification of these value components is possible if value decomposition is performed by integrating and simultaneously applying economic methods and Maslow's theory of needs.

None of the theories have so far attempted to apply similar approach. The theory offered by K. Lancaster (1966) is based on the idea of the complexity of utility, but it does not systemise its components the way Maslow's theory does. Theories like behavioural finance and some other use economics and psychology as a base, but never tried to integrate them to the level that enables value decomposition and has the attributes of synthesis, producing new quality instead of just summarising features from economics and psychology.

Let's start from the hypothesis, which states that if aggregate value of any good or service can be decomposed into ' $n$ ' non-substitute value components, each reflecting a certain level in the Maslow's pyramid of needs, than the possibility does exist to rationally, in a strictly formalized way to manage the expenditure of an individual or household by purchasing only those goods and services available on the market, which have the closest direction of the vector of their aggregate value to the direction of vector representing the specific consumer's preferences in the same ' $n$ ' co-ordinate space.

Maslow-transformation of aggregate value vector. The aggregate value of any good or service can be split into virtual components by using vector or matrix algebra methods and tools combined with Maslow's hierarchy of needs theory. The original Maslow pyramid of needs is comprised of five hierarchy levels 
(physiological, safety, social, esteem and self-actualisation), but the rank of hierarchy levels can be either increased by splitting the original ones into smaller stages or reduced by combining them into larger groups. Suppose we have ' $n$ ' hierarchy levels in the present analysis and neither of ' $n$ ' categories of needs in the hierarchy pyramid can be replaced or substituted by another. For example, basic needs (food to satisfy only nutrition needs, dwelling and clothing to satisfy only physiological needs, etc.) cannot be substituted by either comfort components (safety, social, esteem), nor prestige components (self-actualisation and partly esteem); the same applies to other needs, so all these ' $n$ ' categories shall be considered non-substitutable.

The proof is based on establishing the existence of a relationship between the components of the aggregate value and their prices and that this relationship is predictable within certain limits of accuracy. We always know the market price of the specific good we are looking at; also, we can always find an alternative to this specific good, which might have a lower aggregate value and price, but still be able to satisfy our needs to some limited extent (e.g. to the level, which corresponds the basic needs). Thus, for the same kind of good, we can have at least two price levels, which are different, and the difference between them indicates the cost of our willingness to acquire the more valuable item. Therefore, the possibility does exist of extracting the cost of components of the aggregate value we are interested in, and making choices based on information, which has a quantitative (monetary) dimension.

Suppose that a consumer/household holds financial resources $M$ and uses them for the purchase of goods or services for the price $P$ to satisfy their own needs. Assume the market price of the purchased good corresponds to its aggregate value $V$, where the aggregate value $V$ is a bunch of the good features, which expresses the potential of the good to satisfy the consumers' needs by creating the required utility $U$.

As stated above, the aggregate value $V$ of the good or service is complex and is composed of virtual value components $V_{n}$ :

$$
\bar{V}=\sum_{n=0}^{\infty} \overline{V_{n}},
$$

where $\bar{V}$ and $\overline{V_{n}}$ are vectors in a ' $n$ ' coordinate space.

As it follows from the assumption, the market price of good/service $P_{m}$ is directly related to the magnitude of its aggregate value vector $|\bar{V}|$, i.e.

$$
P_{m} \equiv|\bar{V}| \text {. }
$$

It is obvious that the aggregate value of goods and services is almost always higher than the utility brought by them to the specific consumer as he or she not necessarily needs all the good features (value components) present in the 
bunch or at least in the proportions in which they are presented. The only exception does exist when the utility is equal to the aggregate value, which happens in the case in which the value $\bar{V}$ and the utility $\bar{U}$ vectors are collinear in reference to the vector representing the consumer's preferences in a mentioned ' $n$ ' coordinate space.

The main idea from the analysis is that the consumer almost always, except in some cases, is about to pay a higher price for the goods he purchases. This is because he is expected to pay for the aggregate value (that is what the seller expects and the marketing system works for!), not the components of the aggregate value he really needs, meaning he would pay both for the value he needs and probably some extra value he would prefer to avoid paying for. Even if the good contains all the value components the consumer appreciates, the proportions between them might not fit his expectations. Taking this into consideration, a rational consumer should look for goods that contain the needed set of value components and are priced accordingly $P_{u}$ :

$$
P_{u} \equiv|\bar{U}|
$$

but not the price $P_{v}$, which corresponds its aggregate value.

$$
\text { As } \bar{U} \leq \bar{V}
$$

Consequently $P_{u} \leq P_{v}$

Thus, by simply comparing the price of the good we are looking at with the price of an alternative good with the same purpose, but containing only a basic value, we can guide the purchase process in order to make decisions based on objective, quantitative information about the cost of additional value we appreciate.

The decomposition principle applied enables the projection of consumer preferences having both physiological and psychological origin onto the aggregate value of goods/services and integration with their economic indicators.

\subsection{Consumption Decision-Making Process and the Use of Value Decomposition}

The collinearity and equality of magnitudes of vectors $V$ and $U$ means maximum available utility $U$ produced by the aggregate value $V$ as only in this case the value vector $V$ contains components, which exactly match the consumer's needs in terms of both the content and the required proportions between them in reference to the axis representing the consumer's preferences. The worst case is when the angle between the two vectors is coming close to $90^{\circ}$, meaning that 
consumer's utility from the purchase makes only a tiny fraction from the aggregate value and turns 0 when the angle is equal to $90^{\circ}$. Therefore, it is important for the rational consumer to always know about how the vectors $V$ and consumer's preference vector $U_{p}$ are mutually oriented in the ' $n$ ' dimensional space of preferences (Fig. 2.4). An angle $\varphi$ between the two vectors in the case of $n=3$ can be calculated in the following way.

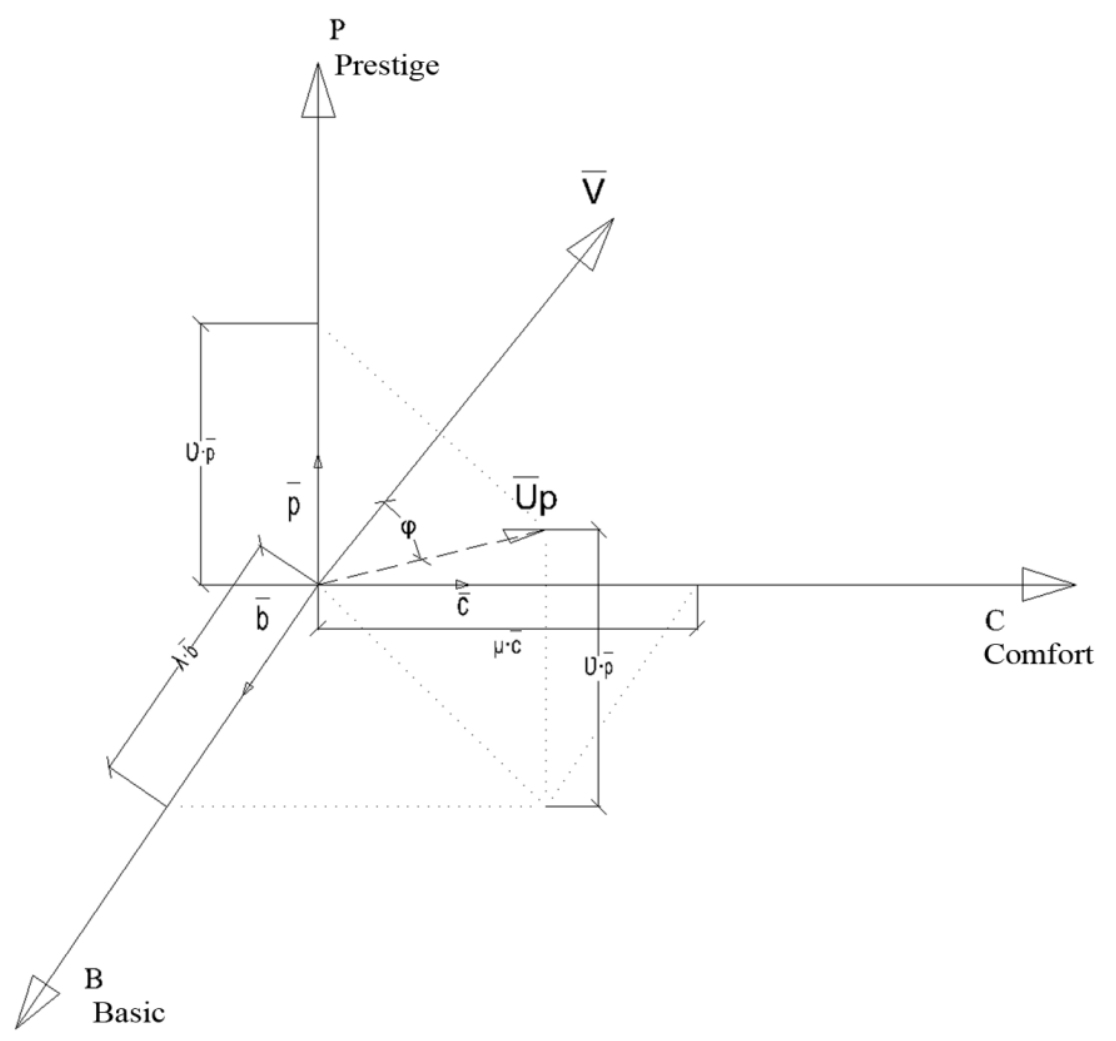

Fig. 2.4. Spatial interpretation of simplified 3-dimensional decomposition of needs (source: author)

Let's say the consumer's preference vector is:

$$
\overline{U_{p}}=\lambda * \bar{b}+\mu * \bar{c}+v * \bar{p} .
$$

Note. Utility vector $U$ is a projection of vector $V$ on the vector of preferences $U_{p}$.

Value vector $\bar{V}$ and utility preference vector $\overline{U_{p}}$ make an angle $\varphi$. If $\varphi$ is $0^{\circ}$, than vectors $\bar{V}$ and $\overline{U_{p}}$ are collinear, which means the aggregate value of the good or service is composed exactly in the way the customer prefers. 
Calculating $\varphi$ :

$$
\begin{gathered}
\overline{U_{p}} * \bar{V}=\left|\overline{U_{p}}\right| *|\bar{V}| * \cos \varphi, \\
\text { If }|\bar{b}|=|\bar{c}|=|\bar{p}|=1,
\end{gathered}
$$

then:

$$
\begin{gathered}
\overline{U_{p}} * \bar{V}=U_{p b} * V_{b}+U_{p c} * V_{c}+U_{p p} * V_{p}=\lambda * b * V_{b}+\mu * c * V_{c}+ \\
v * p * V_{p}=\lambda * V_{b}+\mu * V_{c}+v * V_{p} .
\end{gathered}
$$

According to Equation (2.15):

$$
\begin{gathered}
\left|\overline{U_{p}}\right|=\sqrt{(\lambda * b)^{2}+(\mu * c)^{2}+(\nu * p)^{2}}, \\
\cos \varphi=\frac{\lambda * V_{b}+\mu * V_{c}+v * V_{p}}{\left|\overline{U_{p}}\right| *|\bar{V}|} \\
\varphi=\arccos \frac{\lambda * V_{b}+\mu * V_{c}+v * V_{p}}{\left|\overline{U_{p}}\right| *|\bar{V}|} .
\end{gathered}
$$

Figure 2.5 illustrates the range of change of angle $\varphi$ at variable consumers' preferences and various choices of consumption alternatives applicable to nutrition $(1$ - self-made food from basic products, 2 - semi-fabricated, frozen, 3 semi-fabricated, fresh, 4 - canteen, 5 - cafeteria, 6 - ordinary restaurant, 7 high-class restaurant).

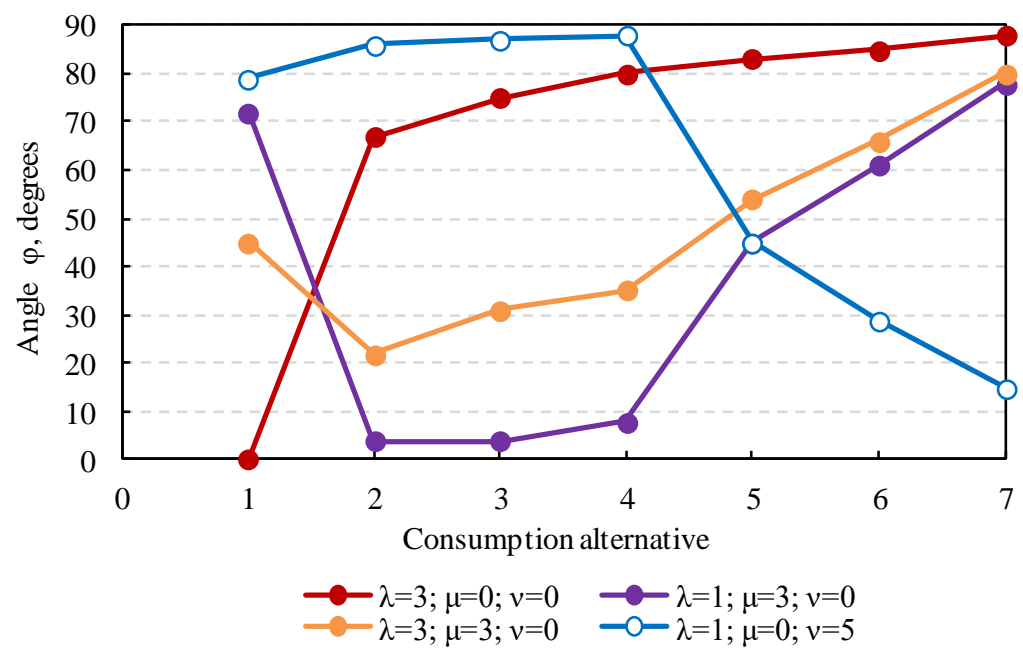

Fig. 2.5. Angle $\varphi$ between consumer's preference vector and the aggregate value vector of goods in focus (source: author) 
The presented graphs show that the consumption pattern, which prefers a basic value $(\lambda=3 ; \mu=0 ; \lambda=0)$, is not compatible with dining in restaurants and even canteens as angle $\varphi$ in this case reaches $70-90$ degrees and, vice-versa, when the consumer prefers prestige and luxury $(\lambda=1 ; \mu=0 ; \lambda=5)$, only alternatives 5-7 are likely to satisfy him or her.

\subsection{Practical Application of Value Decomposition for Control of Consumption Expenditure}

\subsubsection{Value Decomposition as an Integral Part of the Budget Management Process}

Almost any of the numerous budgeting methods and tools in use can serve as a framework and starting point for budget plan formation based on value decomposition. A detailed list of household needs of the budgeting period is being prepared. The list can have any form, but the application of a matrix has certain advantages.

Step 1. The matrix of needs is being formed:

$$
N=\left[\begin{array}{ccc}
n_{11} & \cdots & n_{i 1} \\
\vdots & \ddots & \vdots \\
n_{1 j} & \cdots & n_{i j}
\end{array}\right],
$$

where $N$ - matrix of needs of the budgeting period. $n_{i j-}$ - the quantity of ' $j$ ' need in the ' $i$ 'category of needs, where $1 \leq i \leq s$ and $1 \leq j \leq t$.

Step 2. Price equivalent of the basic value of every item included in the matrix of needs is found. This information can easily be retrieved from the retail market by inspecting and comparing the prices of alternatives offered by the market for each item. Thus, a basic price matrix $N_{B}$ is formed:

$$
N_{B}=\left[\begin{array}{ccc}
n_{11} * \lambda_{11} & \cdots & n_{i 1} * \lambda_{i, 1} \\
\vdots & \ddots & \vdots \\
n_{1 j} * \lambda_{1, j} & \cdots & n_{i j} * \lambda_{i, j}
\end{array}\right],
$$

where $\lambda_{i, j}$ is a price equivalent of the basic value of the $i, j$ need.

The basic budget $B_{b}$ of the period is being calculated:

$$
B_{b}=\sum_{\substack{1 \leq i \leq s \\ 1 \leq j \leq t}}^{s, t} n_{i, j} * \lambda_{i, j} .
$$

This budget is an equivalent of the personal 'living minimum' or 'cost of living' indicator having a monetary dimension and showing household's cost of living if its needs are being satisfied by only using goods and services having a 
basic value. It reminds the officially declared living minimum index, but the difference is that the above budget reflects specific needs of the individual.

Step 3. By applying any of the budget planning methods (e.g. of the iALM type [Dempster, Medova 2011]), the planned disposable income of the household is distributed between current consumption and savings.

Step 4 . The ratio between resources allotted for current consumption $B_{c}$ and basic budget $B_{b}$ is calculated. The ratio $I_{v}$ that is found is called the consumption index:

$$
I_{v}=\frac{B_{c}}{B_{b}}
$$

Step 5. By multiplying every element in the needs matrix by the consumption index $I_{v}$, a preference matrix $P$ of the consumer is formed:

$$
P=I_{v} *\left[\begin{array}{ccc}
n_{11} * \lambda_{11} & \cdots & n_{i 1} * \lambda_{i, 1} \\
\vdots & \ddots & \vdots \\
n_{1 j} * \lambda_{1, j} & \cdots & n_{i j} * \lambda_{i, j}
\end{array}\right] .
$$

This matrix by itself is the price indicator for each item the household intends to buy and could be called a 'Spendometer'. The consumer is free to choose any purchase with the price, which is not higher than the preferential price. Any deviation from this price forms either a budget surplus or deficit, which is automatically registered and displayed by the programs developed in this research (see Appendix C).

Summary of mentioned 5 steps are displayed in Figure 2.6.

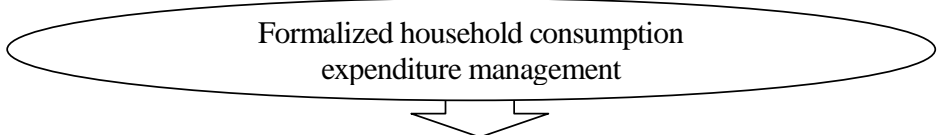

I. Designing of current period needs matrix $(N)$

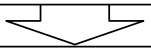

II. Composing of current period budget based on elementary purhases prices $\left(\mathrm{B}_{\mathrm{b}}\right)$

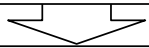

III. Personal finance allocation between current and future consumption

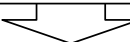

IV. Counting of individual consumption index $\left(\mathrm{I}_{\mathrm{v}}\right)$

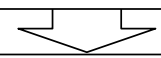

V. Formation of consumer's preference matrix (Spendometer)

Fig. 2.6. Practical implementation steps of value decomposition principles (source: author) 
The preference matrix in reality reflects the Pareto optimum principles (Mathur 1991) as the value of every item to be purchased is uniformly composed in terms of the value components present in it, meaning that the ratio between basic and other values is either the same or very close in each item. By following this principle, everyone can be certain that the needs of the household are satisfied with no danger that expenditures exceed the set current period budget $B_{c}$, and the aggregate utility gained from the whole bunch of purchased items is about to be the Pareto optimal.

The test programs developed in the research are based on MS Excel and are intended for household's nutrition budget planning (See Appendix C).

\subsubsection{Advantages of Using Value Decomposition for Expenditure Management on Elementary Purchases and the Aggregate Consumption Level}

What effect in price reduction can be expected in case the decomposition principles are applied for consumption expenditure management? Several examples illustrating the answer to this question are presented below.

Case Study 1. Table 2.2 includes price information on drinking water available from the municipal drinking water supply system and purchased in bottles from supermarkets. As it follows from the table, the price level can differ up to several thousand times (!) even though the product's functional value is similar and all are interchangeable.

Table 2.2. Comparison of drinking water prices (source: author)

\begin{tabular}{l|c|c|c|c}
\hline \multicolumn{1}{c|}{ Drinking water types } & Volume, l & $\begin{array}{c}\text { Price, } \\
\text { EUR/unit }\end{array}$ & $\begin{array}{c}\text { Price per 1, } \\
\text { EUR }\end{array}$ & $\begin{array}{c}\text { Price differ- } \\
\text { ence, times }\end{array}$ \\
\hline S. Pellegrino & 0.25 & 1.09 & 4.36 & 2868 \\
\hline Akvilè & 0.25 & 0.56 & 2.24 & 1474 \\
\hline Neptūnas & 0.3 & 0.64 & 2.13 & 1404 \\
\hline Tiché & 0.33 & 0.7 & 2.12 & 1396 \\
\hline Tichè & 0.33 & 0.1 & 1.24 & 817 \\
\hline S. Pellegrino & 1 & 1.24 & 1.24 & 816 \\
\hline Birute & 0.5 & 0.45 & 0.90 & 592 \\
\hline Naleczowianka & 0.5 & 0.37 & 0.74 & 487 \\
\hline Naleczowianka & 1.5 & 0.67 & 0.44 & 294 \\
\hline $\begin{array}{l}\text { Water from municipal drink- } \\
\text { ing water supply system }\end{array}$ & 1000 & 1.52 & 0.0015 & 1 \\
\hline
\end{tabular}


Case Study 2. Assume the consumer is looking for a watch, and he can choose from two alternatives: an acceptable quality product, priced 20 Euro from a manufacturer specialised in mass production and the famous Rolex brand, priced from 5000 to probably 30000 plus Euros. Both products are of same category of goods by application - the devices to measure and indicate time, but the composition of value in each case is completely different. Rolex would contain both the value of the watch itself, which would not dramatically differ from the cheap alternative, but will also contain value component representing prestige, which would present more than $99 \%$ of its price. The value and price of a cheap watch, on the contrary, would reflect the value of a time measuring device by $99 \%$, while the prestige value would of course be close to zero. Both products have their own consumers in the market, but let us imagine they have exchanged their positions. What would be the consequences, especially for the one who by mistake has bought a Rolex instead of a cheap alternative? Probably he would put in danger not only himself but also his family just because he has ignored the composition of value and had purchased a product whose value is hundreds, maybe even thousands times higher than the specific utility he needed.

Case Study 3. Assume a pensioner having a very low income purchases a cup of coffee in an expensive restaurant located in a busy city-centre shopping area and pays some 5 to 10 times the price available in other places. The questions are: which value components make the price so high in this case and is this consumer aware of and in need of them?

These examples show that in many cases there is no problem in identifying the price, which corresponds to the basic value of a good or service. In case of drinking water, it is the price offered by the municipal utility system. In the case of watches, it is the price of the mass production watch, and in the case of a cup of coffee, it would be the price in another, least expensive location. It is obvious how important it is to be aware of one's own needs and act accordingly in the consumer market, as consequences of ignoring it, might be negative and even dramatic as the price paid for a good by a consumer can be so many times higher than its basic price.

Similar results provide a comparison of the prices of separate items as well as aggregate budgets of specific categories of needs (e.g. nutrition) or the aggregate consumption.

Table 2.3 below presents the prices of value components of the same dish prepared by the consumer himself from raw products purchased in supermarkets and the same product purchased as a semi-fabricated product or consumed in a canteen or restaurant. As it follows from the table, the price level can differ many times depending on the composition of value of the dish. 
Table 2.3. The effect of value components on aggregate price of the dish having same nutritional value (source: author)

\begin{tabular}{|c|c|c|c|c|c|c|c|c|c|}
\hline \multirow[t]{2}{*}{ Catering types } & \multirow{2}{*}{$\begin{array}{l}\text { Price } \\
\text { per } \\
100 \mathrm{~g} / \\
\mathrm{cnt}\end{array}$} & \multirow{2}{*}{$\begin{array}{l}\text { Price } \\
\text { per } \\
\text { kcal, } \\
\text { cnt }\end{array}$} & \multirow{2}{*}{$\begin{array}{l}\text { Change } \\
\text { of aggre- } \\
\text { gate val- } \\
\text { ue, times }\end{array}$} & \multicolumn{3}{|c|}{$\begin{array}{l}\text { Aggregate value distri- } \\
\text { bution by components } \\
\text { in relative units }\end{array}$} & \multicolumn{3}{|c|}{$\begin{array}{l}\text { Aggregate value } \\
\text { distribution, } \%\end{array}$} \\
\hline & & & & Basic & Comfort & Prestige & Basic & Comfort & Prestige \\
\hline Basic products & 0.16 & 0.07 & 1.0 & 1 & 0 & 0 & 100.0 & 0 & 0 \\
\hline $\begin{array}{l}\text { Semi- } \\
\text { fabricated } \\
\text { dishes, frozen }\end{array}$ & 0.41 & 0.18 & 2.6 & 1 & 1.6 & 0 & 38.5 & 61.5 & 0 \\
\hline $\begin{array}{l}\text { Semi- } \\
\text { fabricated } \\
\text { dishes, fresh }\end{array}$ & 0.63 & 0.28 & 3.9 & 1 & 3 & 0 & 25.0 & 75.0 & 0 \\
\hline Canteen & 0.89 & 0.39 & 5.6 & 1 & 4.6 & 0 & 17.9 & 82.1 & 0 \\
\hline Cafeteria & 1.23 & 0.54 & 7.7 & 1 & 4.6 & 2.2 & 12.8 & 59.0 & 28.2 \\
\hline $\begin{array}{l}\text { Restaurant, } \\
\text { middle class }\end{array}$ & 1.82 & 0.80 & 11.4 & 1 & 4.6 & 5.9 & 8.7 & 40.0 & 51.3 \\
\hline $\begin{array}{l}\text { Restaurant, } \\
\text { upper class }\end{array}$ & 4.05 & 1.79 & 25.5 & 1 & 4.6 & 20.1 & 3.9 & 17.9 & 78.2 \\
\hline
\end{tabular}

The same results are reflected graphically in Figure 2.7.

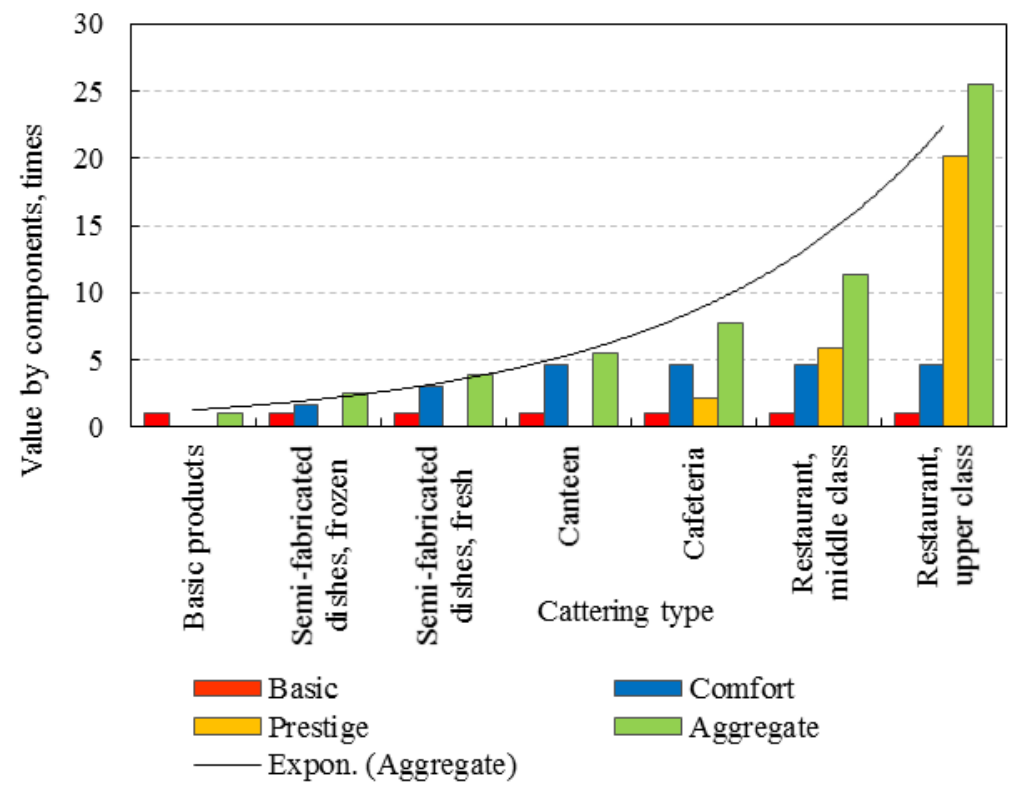

Fig. 2.7. Differences between basic, comfort and prestige value prices (source: author) 
Table 2.4 compares the cost of nutrition if needs are satisfied by using only basic products, meaning that they contain only the basic value. This indicates the range of nutrition cost variation when products consumed represent different price levels, both the cheapest and most expensive. Several hundred products were sorted by nutrition type (fat, carbohydrate or protein) and graded by price per calorie into five grades. It is remarkable that changing from the cheapest to most expensive grade only, gives a price difference between 5-8 times, which is comparable to changing from eating at home to a canteen not mentioning dining out in restaurants. This means that the price of comfort provided by the canteen is adequate to changing from the cheapest to most expensive basic products.

The performed case studies suggest that the application of value decomposition can help consumers raise their awareness about the value and price composition of goods and services available on the market while budget management tools based on them could increase the efficiency of financial resource management in households.

Table 2.4. The price grades of basic food products in Lithuania (source: author)

\begin{tabular}{|c|c|c|c|c|c|c|c|c|}
\hline \multirow{2}{*}{$\begin{array}{l}\text { Grade of } \\
\text { basic } \\
\text { products }\end{array}$} & \multicolumn{3}{|c|}{ Daily nutrition cost, EUR } & \multirow{2}{*}{$\begin{array}{l}\text { Total, } \\
\text { EUR/d } \\
\text { ay }\end{array}$} & \multirow{2}{*}{$\begin{array}{l}\text { Cost } \\
\text { differ- } \\
\text { ence, } \\
\text { times }\end{array}$} & \multirow{2}{*}{$\begin{array}{l}\text { Total, } \\
\text { EUR/m } \\
\text { onth }\end{array}$} & \multirow{2}{*}{$\begin{array}{l}\text { Statistical } \\
\text { consump- } \\
\text { tion index, } \\
\text { relative to } \\
\text { the grade }\end{array}$} & \multirow{2}{*}{$\begin{array}{l}\text { Consumption } \\
\text { index with } \\
\text { individual prefer- } \\
\text { ential nutrition } \\
\text { budget in EUR }\end{array}$} \\
\hline & \begin{tabular}{|l} 
Carbo- \\
hydrates
\end{tabular} & Fat & $\begin{array}{l}\text { Pro- } \\
\text { tein }\end{array}$ & & & & & \\
\hline \multicolumn{7}{|c|}{ Average nutrition cost (statistics) } & 78 & 145 \\
\hline 1 & 0.24 & 0.08 & 0.18 & 0.50 & 1.00 & 15.1 & 5.17 & 9.58 \\
\hline 2 & 0.37 & 0.14 & 0.47 & 0.98 & 1.95 & 29.5 & 2.65 & 4.90 \\
\hline 3 & 0.86 & 0.21 & 0.67 & 1.74 & 3.45 & 52.1 & 1.50 & 2.78 \\
\hline 4 & 1.61 & 0.36 & 0.88 & 2.85 & 5.65 & 85.4 & 0.91 & 1.69 \\
\hline 5 & 2.01 & 0.54 & 1.46 & 4.00 & 7.95 & 120.1 & 0.65 & 1.20 \\
\hline Average & 1.02 & 0.27 & 0.73 & 2.02 & 4.00 & 60.5 & 1.29 & 2.39 \\
\hline
\end{tabular}

Identifying the right value and price of a good/service and focusing on it while making consumption expenditure-related decisions can be called harmonisation of consumption, as consumers' decisions in such a case would be harmonised to his or her specific needs, meaning that the use of financial resources for value components that have no utility for him or her shall be minimised. Analysed examples are quite evident and easy in terms of distinguishing the value components. In the case of other goods and services, it might be more complicated because value is so complex and difficult to analyse and distinguish even if the decomposition principles themselves are well understood. 
In a similar way, the situation can be analysed not only on a microeconomics, but also on a macroeconomics level, when estimating the financial performance of households of an entire country.

Case Study 4. Let us compare a situation with average statistical households in two OECD (Organization for Economic Co-operation and Development) countries - Greece and Estonia. The two countries were selected for comparison as both are OECD members and the statistics available on them were produced based on the same standards and are comparable with a high degree of confidence.

The situation in Greece is nowadays widely discussed on an international scale, first of all, stressing the disappointment of Greek society with a worsening living standard, while Estonia is considered to be a relatively stable country from both economic and social points of view. Is it so that Estonian households dispose higher resources for satisfying their needs than the Greek households do? Alternatively, maybe are living costs in Estonia much lower? Statistics say that neither is true. The average income adjusted to purchasing power per household in 2012 in Greece was 20,300 EUR compared to 13,800 EUR in Estonia, while consumer price indexes (in 2015) were only slightly higher in Greece (consumer plus rent price index 41.5 compared to 39.2, groceries price index 58 compared to 49). Only the restaurant price index in Greece is noticeably higher: 70 compared to 51 (Numbeo 2015). The average pension in Greece is also much higher; therefore, there is no other explanation to justify the problems that Greek households face other than a possible significant difference in value (and price!) of a total bunch of needs because of a different lifestyle and probably different habits.

The World Bank (2012) provides similar statistics, which show that in 2011 annual consumption expenditure per person in Greece was 18,600 Euro, while in Estonia it was $~ 9,000$ Euro (in Lithuania 8700 Euro). The situation had slightly changed in 2014, when average consumption in Greece shrank to 15,500 and increased in Estonia to 10,200 Euro (in Lithuania to 10,400 Euro).

Analysis based on data from the US Department of Agriculture and EuroMonitor International (EuroMonitor International 2013) indicates that the amount Greek residents spend on food at home, dining out, alcohol and tobacco is among the 15 highest in the world. The amount spent on restaurant meals only $(1,158$ US\$) is comparable to the total annual food expenditure per person in Lithuania. The Greek people spent more than those of any other country in the world at cafés in 2012 - 609 US\$ per person (The World Post 2015).

If an individually set consumer's nutrition budget corresponds to grade 2 (Table 2.4), then an average statistical consumption index in Lithuania is close to 3 (2.65), while in Greece it should amount to 12. As basic prices in both countries are close, such a big difference in the value of the consumption index 
can only be justified by the dining out practice, which is much more common in Greece than in Lithuania.

As it follows from the examples, analysis based on value decomposition can provide at least some ideas regarding why certain phenomena take place not only in separate households, but also on a macroeconomics level as well. On the other hand, this demonstrates the significant potential of value decomposition being applied by households as a management tool for their consumption expenditures.

\subsection{Conclusions of Chapter 2}

1. Analysis of relevant theories and management tools shows that the majority of them ignore the influence of psychological factors on decision-making related to expenditure management. Furthermore, they analyse processes on a certain generalised level and do not go deep enough to enable rational decision-making when it comes to the purchase of every single item, which finally form a bunch satisfying consumers' total needs. The management procedures used are usually limited to registration of the purchase or, if allowed, alternatives that can be analysed on a level, which does not go deeper than the total price of the item and its full (aggregate) value. It has been shown that such an approach is not consistent from the point of view of consumers' needs as an aggregate value does not necessarily match their personal utility criteria. The purchase process in such a case fully relies on consumers' rationality, which is subject to intuition, experience, instant mood and other subjective factors. It is difficult to avoid contradicting decisions and unbalanced consumption and to guarantee maximal utility from the expenditure under these circumstances.

2. The influence of the above-mentioned subjective factors on expenditure management decisions could be reduced if the decisionmaker would possess information, sufficient to judge whether the item to be purchased matches his or her specific needs and if it is priced accordingly. This could be achieved if a special pre-purchase matchmaking block would be integrated into expenditure management algorithms to produce necessary information. Such a matchmaking block can be formed by integrating and simultaneously using elements from economics and psychology (as referred to in Maslow's theory of needs).

3. The theoretical principles of a new approach to the management of households' expenditure have been proposed. The key element of the 
approach is the decomposition of the aggregate value of goods/services into components, each reflecting a certain level of Maslow's pyramid of needs and enabling their matching with the consumer's preferences. Thus, consumer preferences, having both physiological and psychological origin, are projected onto the aggregate value of goods/services and integrated with their economic (price) indicators.

4. The proposed approach makes it possible to quantitatively evaluate and compare the value components representing different levels of the Maslow pyramid of needs and estimate the respective costs of consumer's needs and wishes.

5. The offered vector decomposition of the aggregate value of goods/services enables comparison of the selected good/service with the consumer's preferences by comparing the magnitudes and spatial angles of the aggregate value and the preferences' vectors. A method for calculating the angle between the vectors has been developed.

6. Case studies in microeconomics and macroeconomics segments have proved the validity of the approach and its potential for being applied as a planning tool in managing households' expenditures. Reduced dependence on subjective decisions limits spontaneous spending, gives the possibility of harmonising not only total/aggregate consumption with income, but also to find a balance between each item in the bunch of products/services being purchased, thus preventing an unbalanced (excessive or insufficient) allocation of funds for consumption. 



\section{Modelling of a System for Consumption-Related Monetary Flow Guidance Based on Modified Cooperation between Households and Retail Banks}

In this Chapter, the reasons causing the insolvency of individual bank clients are analysed and graded according to their influence on the level of non-performing loans in commercial banks. The possible ways to control most influential factors were analysed. As both, the households and commercial banks, have a common interest to seek for more efficient financial resource management in households, an idea for the modification of the existing cooperation between them was developed. The idea presumes that it might be beneficial for banks to take preventive actions to help reduce their loss caused by non-performing loans by investing into the development of an education system for their clients. A method for estimating the payback of investment was developed as well as preliminary calculations performed to support the proposal. A system comprised of a formal approach used to control the household consumption expenditure on the elementary purchases level (see Chapter 2) and the idea to educate the bank clients with the aim of improving 
the quality of personal consumption expenditure on the aggregate monetary flow level is presented in the Chapter.

Results of investigations in Chapter 3 are published in two author's publications (Taujanskaitė, Milčius 2014; Jurevičienė, Taujanskaitė, Sukačevskytė 2016).

\subsection{Personal Insolvency Reasons}

During the last two decades, loans issued to insolvent persons have become a major problem in a number of countries (Baek, Hong 2004; Keese 2009; Anderloni, Vandone 2010; Christelis et al. 2010; International Monetary Fund 2013). Researchers have started to investigate the causes of insolvency (Lusardi 2006; Jappelli et al. 2008; Meniago et al. 2013; Kamleitner, Kirchler 2007; Pahl 2008).

Various scientific investigations have been carried out and revealed the correlation between insolvency and a variety of factors influencing it (e.g. altering macroeconomic environment, interest rate fluctuations, family lifecycle changes, financial resources management skills, etc.) (Baek, Hong 2004; Walters, Smith 2010). Some of these factors have a clearly expressed, quantitative (monetary) effect on the flow of households' financial resources; consequently, their impact on a person's solvency can be easily forecasted. Thus, these factors have been thoroughly researched. Another group of factors are demographical, socioeconomic, cultural as well as those related to financial literacy, etc., which affect a person's solvency indirectly. Their influence on solvency is subject to sociocultural environment in the society, traditions and other circumstances, which are difficult to define quantifiable. According to Anderloni et al. (2012), the influence of the latter factors should be researched 'in different countries in order to exploit crosscountry differences'.

\subsubsection{Theoretical Aspects of Insolvency Interpretation}

The term personal 'insolvency' is described differently by various researchers. The concepts of solvency and its opposite, insolvency, can be simply defined as having either a positive or negative net worth. In the equity sense, insolvency refers to the failure to submit timely debt repayment at maturity (De Vaney, Lytton 1995). This situation can result as an increase in liabilities and a reduction in equity or assets held. In the bankruptcy sense, insolvency means that net assets at fair market value are less than liabilities, which can necessitate the liquidation of assets through a court-ordered bankruptcy process (De Vaney, Lytton 1995).

Reifner et al. (2003) highlights the differences in the term 'insolvency' in many countries. In Belgium, it is described as 'incapability of paying debts', in 
Great Britain: 'as an inability of the debtor to pay the debt on which the petition is based, or in cases where the debt is not immediately payable, or the debtor appearing to have no reasonable prospect of being able to pay the debt'. In Austria, insolvency is described according to the Austrian Bankruptcy Code: a) Opening of the bankruptcy proceedings presupposes that the debtor is insolvent. b) Insolvency has to be accepted in particular if the debtor stops his payments. c) Insolvency does not presuppose that creditors crush. The circumstance in which the debtor satisfied demands of individual creditors totally or partly or still can satisfy, does not of itself justify the acceptance that he is solvent'.

The formulations above are taken from legal documents, which regulate various processes of problematic and risky loans. In addition, there are other streamlined formulations defining the problematic financial situation of individuals according to scientific literature. For instance, 'financial fragility' (Jappelli et al. 2008), 'financial vulnerability' (Anderloni et al. 2012), etc. These concepts also define that a person has financial problems and is unable to fulfil his obligations on time.

In literature, the term insolvency defines quite a wide spectrum of problems from inability to pay loan instalments on time to personal bankruptcy. Considering everything, these conditions can be classified as follows (Table 3.1).

Table 3.1. Levels of financial problems in household (Jurevičienè et al. 2016)

\begin{tabular}{l|c|c|l|c}
\hline $\begin{array}{l}\text { Level of the } \\
\text { problem }\end{array}$ & Definition & $\begin{array}{c}\text { Duration } \\
\text { of the } \\
\text { process }\end{array}$ & \multicolumn{1}{|c|}{ Possibilities } & \multicolumn{1}{c}{$\begin{array}{c}\text { Scientific } \\
\text { researches }\end{array}$} \\
\hline $\begin{array}{l}\text { I level: In- } \\
\text { debtedness }\end{array}$ & $\begin{array}{c}\text { More than 1 } \\
\text { day payment } \\
\text { delay }\end{array}$ & Short & $\begin{array}{l}\text { The person has reve- } \\
\text { nue/asset and can pay his } \\
\text { debt as soon as possible. } \\
\text { The debt occurred because } \\
\text { of forgetfulness, holidays or } \\
\text { etc. }\end{array}$ & $\begin{array}{c}\text { Lusardi, Tufano 2009; } \\
\text { Brown, Taylor 2008; } \\
\text { Alfaro, Gallardo 2012; } \\
\text { Kim } \text { et al. 2014 }\end{array}$ \\
$\begin{array}{l}\text { II level: In- } \\
\text { solvency }\end{array}$ & $\begin{array}{c}\text { More than 60 } \\
\text { days payment } \\
\text { delay }\end{array}$ & Medium & $\begin{array}{l}\text { The person has no reve- } \\
\text { nue/asset and can't pay his debt } \\
\text { promptly. The debt occurred } \\
\text { due to job loss, illnesses, criti- } \\
\text { cal changes in family structure } \\
\text { and etc. }\end{array}$ & $\begin{array}{r}\text { Reifner } \text { et al. 2003; } \\
\text { Bishop 2013. }\end{array}$ \\
\hline $\begin{array}{l}\text { III level: } \\
\text { Bankruptcy }\end{array}$ & $\begin{array}{c}\text { Unable to pay } \\
\text { debts }\end{array}$ & Long & $\begin{array}{l}\text { There is no possibility to pay } \\
\text { debts in several years and even } \\
\text { higher income level would not } \\
\text { help to solve the problem. }\end{array}$ & $\begin{array}{r}\text { Walters, Smith 2010; } \\
\text { Wyburn 2014. }\end{array}$ \\
\hline
\end{tabular}


In this study, the term insolvency defines a payment delay of more than 60 days, but it also dissociates from bankruptcy. The delayed loan itself is called an unsecured or risky loan (based on the classification of the Bank of Lithuania), and the risk, which the financial institution faces due to the unrecovered liability of the insolvent debtor, shall be called insolvency risk.

\subsubsection{Classification of Insolvency Causes}

Baek and Hong (2004) analysed insolvency problems in the USA based on the life cycle hypothesis. They linked household debts with different human lifecycles and changing needs. They highlight that it is difficult to finance new needs and harmonise them with current financial liabilities.

Prinsloo (2002) relates the personal debt level with the general country's economic situation in the Republic of South Africa. Meniago's et al. (2013) research also proves that macroeconomic factors determine an individual's financial situation and solvency. This also been confirmed in subsequent research by Meng et al. (2013). Results show that the borrowing of Australian households is directly correlated with the growth of the country's GDP. Interest rates, inflation and the level of unemployment are those macro-economic factors that have an impact on the fulfilment of further financial liabilities.

Ogawa and Wan (2007) relate the emergence of risky loans in the Japanese credit market with increased households' consumption expenses. The rapid growth of consumption, if it is funded not by one's own resources, but by loans from financial institutions, is indicated as the main reason for the increasing number of people who face insolvency problems.

Jappelli et al. (2008) analysed the borrowing habits of households in Great Britain, Germany and the USA and indicated three main factors that may affect the indebtedness of individuals and their default rates: 'a) institutional features that shape the market's contracting environment, such as the degree of creditor rights protection, the effectiveness of their legal enforcement, and the information sharing arrangements among lenders; b) demand-side factors, such as the age structure of the population and the degree of income inequality; c) supply-side factors, such as the competitive structure of the credit market'.

Kirchler et al. (2008) relate insolvency with one's family status or it's change, age, number of children in the family, etc. and call them 'situational characteristics'.

Worthington (2006) researched the Australian credit market and linked the dynamics of a portfolio of risky loans with demographic and socioeconomic factors that influence client's financial behaviour. Wang et al.'s (2011) analysed the Chinese credit market and found that demographic and individual personal features, such as responsibility, self-control and even self-respect majorly determine whether or not an individual shall make loan payments on time in the future. This article also classifies research of this problem into two cathegories: a) studies, 
where the fulfilment of financial liabilities are analysed in a systemic way taking into consideration economic, demographic and psychological factors; and b) studies, where separate factors are being analysed (e.g., fulfilment of financial liabilities) and linked with certain factors, like credit risk management policy of the financial institution or the client's personal finance management habits, etc.

Anderloni et al. (2012) analyse the growth of insolvent households in Italy from the point of view of sociodemographic and economic factors and indicate four possible reasons for financial vulnerability: 'a) presence of unplanned expenses, b) high volume of current liabilities, c) impulsive, uncontrolled consumption and its growth, d) lack of financial knowledge'. They admit these factors are the most vulnerable for the credit market. This kind of loan is usually unsecured and individuals repay them at the latest.

Kim et al. (2014) noticed that in the last decade in Korea there has been a rise of household debts in financial institutions and that this situation could have been affected by three factors: a) the increase of property prices, b) beneficial and 'relaxed' borrowing conditions to get a loan, and c) decrease in the growth of household income level.

Disney and Gathergood (2013) researched the UK consumer credit market and concluded that individuals who have poor financial knowledge more often fail to meet their financial obligations. Moreover, the credit expenditure is often judged incorrectly as people fail to calculate the real borrowing price, which is influenced by rather high credit interest rates. These individuals also tend to understand borrowing deadlines as unlimited and ongoing; therefore, they often fail to make timely instalments, being unable to define the consequences.

Jurevičienè and Sukačevskytė (2013) similarly identified that failure to repay loans is directly linked to the lack of households' financial management skills. This means that households, that cannot or are unable to manage their finances adequately, are more likely to face insolvency problems.

There are many discussions regarding whether income level relates to the ability to meet financial liabilities. For instance, Keese (2009) states that the volume of income does not have a direct impact on the client's solvency, unless a fluctuation of income is happening at the same time as another event (e.g. change in the number of family members, divorce, death of a spouse, etc.). Later, Anderloni and Vandone (2010) proved that the presence of insolvency does not correlate with income level. Higher income does not guarantee timely loan repayment. This is also confirmed by Christelis et al. 's (2010) investigation, where it becomes apparent that even those households that are wealthy and have higher income than average are still facing difficulties in fulfilling their obligations. Research results by Taujanskaitė and Milčius (2012) likewise confirm this. Households with higher income than a country's average level more often face budget deficits compared to those with average or below average income. 
The findings of Alfaro and Gallardo's (2012) research are completely different. After examining mortgage and consumer credit markets in Chile, they found that the only factor influencing the solvency of an individual is the level of income, while demographic or various personal factors can only be identified as supplementary reasons. They also stated that the probability of insolvency decreases if there is an increase in household income. Giarda (2013), who was investigating reasons of insolvency in Italian households, also confirms this: financial vulnerability decreases if there is personal income growth; however, insolvency could increase in those areas where unemployment growth exists. Thus, the results of investigations on correlation between income level and the presence of debts are very controversial.

Summarising the literature review, it can be stated that solvency of an individual can be affected by a number of factors: general economic situation in the country, unemployment rate, borrowing system features, and others (e.g. financial knowledge and ability to manage financial resources, sense of duty and responsibility, ability to control ones consumption behaviour, etc.).

With regard to the above-mentioned factors, relating it with household cash flows, the factors that influence the presence of insolvency were divided into two groups (Fig. 3.1):

- Direct factors that influence an individual's cash flows directly (e.g. the country's overall economic situation, unemployment rate, fluctuations of income level, etc.). These factors and their influence can be defined quantitatively as they have financial/monetary dimension.

- Indirect factors that influence personal cash flows indirectly (e.g. age, educations, marital status, financial literacy, etc.) and do not have a defined quantitative financial/monetary dimension.

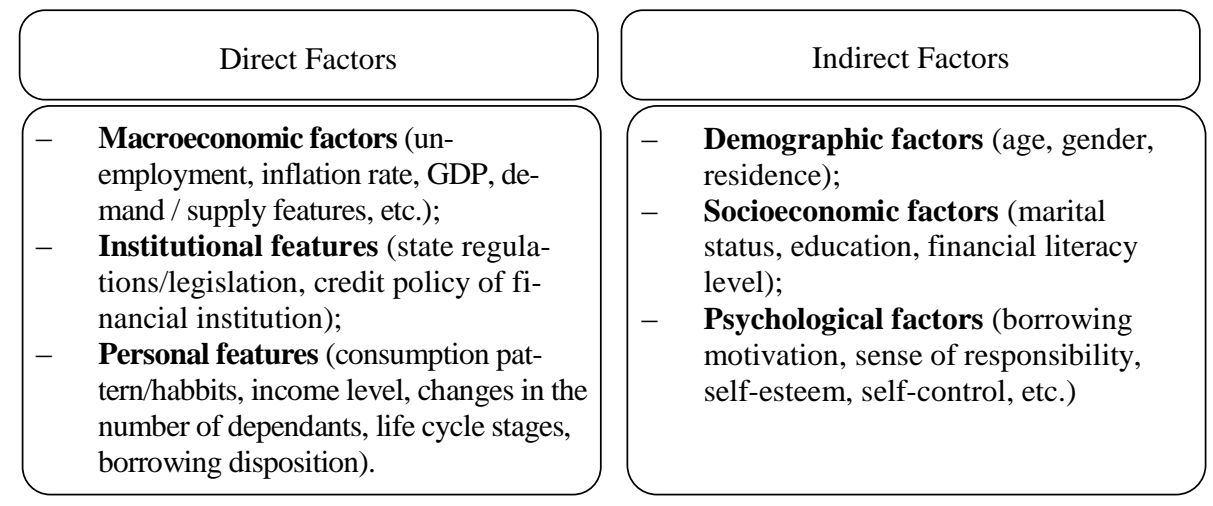

Fig. 3.1. Factors determining insolvency according to their relation to an individual's financial flows (created by author according to Jurevičienè et al. 2016) 
Further analysis of factors affecting individual's solvency has been performed based on this classification.

\subsection{Effect of Direct and Indirect Factors on Borrower Performance of Bank Clients}

Two researches have been conducted to analyse the influence of direct and indirect determinants influencing personal insolvency. First research covered demographic (gender, age), socioeconomic (residence, family status) factors and those, including credit and repayment (credit amount, income level ${ }^{1}$ ) as well as aspects describing borrowing motivation (purpose of credit).

Data for the first research was taken from Lithuania's consumer credit market financial institution (2012). Survey sample -400 consumer credit contracts, bias $5 \%$, probability $-95 \%^{2}$. To ensure compatibility, the age group of 15-19 years was eliminated as credits can be granted only for people over 18 in Lithuania and there are no borrowers beyond age of 20 in the sample. Data were processed and correlation analysis was made by using statistical program SPSS. All expanded investigations about indirect factors are published in the article (Jurevičienè et al. 2016).

The main findings of this investigation were:

- Men are more likely to undertake financial obligations than women.

- Women borrow smaller sums than men.

- The average age of a woman who has a loan is 42 years old, of a man - 37 years old.

- Consumer credit demand is much higher amongst young people (20-49 years old category), compared to the ones who are older than 50.

- Residents of large cities are more likely to use credit compared to those who live in towns and villages.

- There are $12 \%$ more men debtors than women.

- Married or widowed people are more responsible in the fulfillment of liabilities on time compared to divorced or single ones.

\footnotetext{
${ }^{1}$ Income level is additionally involved into indirect factors set to verify their impact on default in the range of current sample due to contradictory conclusions regarding their impact in various publications.

${ }^{2}$ Computed with special program : http://www.factus.lt/main-calculator.
} 
- If an individual has more than one financial obligation, the probability exists that he will enter the list of insolvent clients. The more liabilities a person has, the higher the probability is to become insolvent in the future.

- It was identified that residence has no impact on solvency. Research findings did not show any tendencies, allowing one to forecast better financial liabilities repayment relating it to the client's living place.

- Due to controversial evaluations in the scientific literature about the impact of income level on solvency, the relationship of income and obligations fulfillment was investigated even this factor belongs to direct. Findings indicate that in this research, the level of income does not correlate with the debt sum. They do not support the expectations that once an individual's income increase, the amount of debt would decrease and vice versa.

The investigation has proven that from all analyzed indirect factors, the risk of lending is first of all subject to borrowing motivation. It has been revealed that the majority of risky loans are intended for financing of expensive purchases or excessive consumption, while those for current debts refinancing were fulfilled more responsibly. As a result, borrowing motives from all indirect determinants appeared to be the main reason for individual's failing to fulfill contracts, while other analyzed factors such as demographic and socioeconomic had no significant impact.

It is possible to claim that motivation of borrowing can be influenced by excessive consumption and supportive environment for this, also competition between creditors within the consumer credit market, ability to manage ones needs and adequately understand the terms and conditions of borrowing.

The second research was conducted by involving banking professionals as experts for listing and quantitative evaluation of major factors, which determine non-performing loan ratio.

\subsubsection{The Setup of Expert Evaluation Survey}

The analysis of household-related financial flows and budgetary performance of households (Chapter 1) suggest that these can be closely linked with performance of commercial banks active in retail banking. In order to identify the main factors that affect insolvency of individual clients of commercial banks, an empirical analysis by expert evaluation method was conducted in June - July 2015. Expert evaluation is a tool, which: a) allows to get specific information from certain specialists that could not be delivered from literature or general statistics; b) exploits expert knowledge accumulated by professionals in a specific area, who have experience, a large amountcy information (Rudzkienè 2014). 
The plan of expertise procedures is displayed in Figure 3.2.

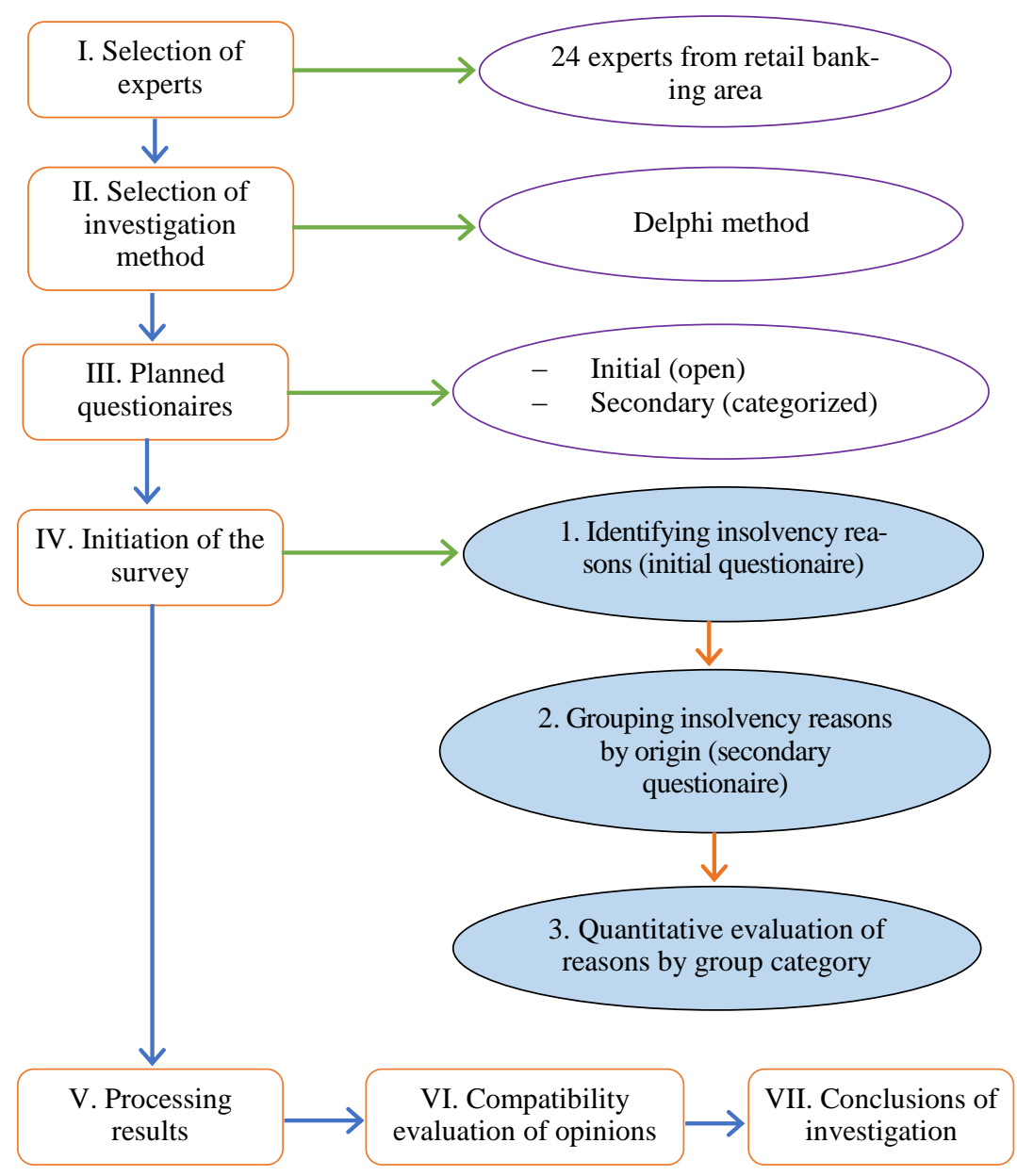

Fig. 3.2. Main steps of expert evaluation procedure (source: author)

The research was conducted in 7 stages:

I. Selection of appropriate experts.

Following the topic of the investigation, experts were selected from the retailbanking segment. All of them have been dealing with non-performing loans and the insolvency issues of personal clients. 


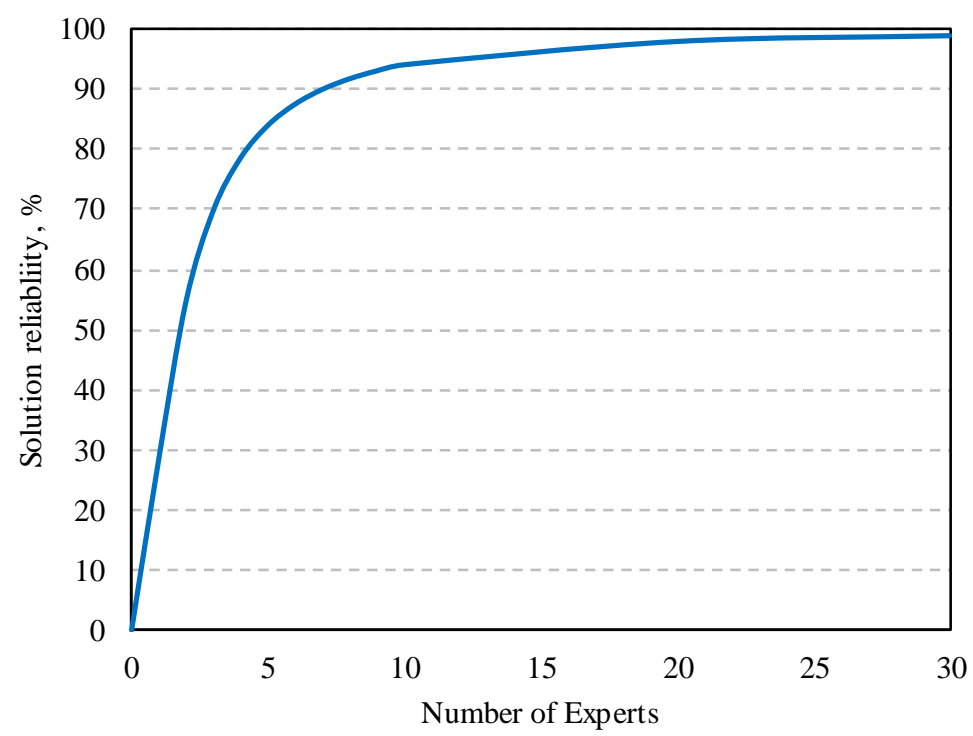

Fig. 3.3. The dependence of the standard deviation of expert evaluation upon the number of experts (Rudzkienè 2014)

The number of experts was selected following the diagram in Figure 3.3 indicating that if the number of experts is equal to 12 or higher, it guarantees accuracy more than $90 \%$, but a further increase in the number of experts increases the accuracy only marginally.

With the aim of having the accuracy of the investigation not less than 95\%, 24 experts were selected from Lithuanian banking and financial sectors and interviewed:

- 19 experts representing five commercial banks.

- Three experts from a debt collection company.

- Two independent experts: a business consultant from the finance sector and a personal finance management consultant.

Additional information on experts.

Areas of expertise: 19 experts representing commercial banks work in specific departments that are responsible for the debt management of individual clients (Debt collection and litigation, credit administration, credit risk management, pretrial debt collection, debt administration and recovery); three experts specialise in banking customer service and sales and two work individually with finance management issues. Positions: six top managers, the heads of Debt collection and litigation, Pre-trial debt collection, Litigation department, Credit risk management, 
Debt administration, Customer service and sales departments; three experts are senior managers: senior credit administrator, senior credit risk specialist, senior analyst; three lawyers; 12 other specialists: two loan consultants, one debt consultant, one credit administrator, six managers, one business consultant, and one personal finance manager. Experience: all experts have professional experience in an appropriate sector from 1 to 23 years.

\section{Selection of Delphi method.}

The Delphi technique, mainly developed by Dalkey and Helmer (1963) in the 1950s, is a widely used and accepted method for achieving convergence of opinion concerning real-world knowledge solicited from experts within certain topic areas (Hsu, Sandford 2007). According to Landeta (2006), it is timetested and one of the most accurate techniques used in the social sciences for assessing opinions and forecasting and making decisions on problems that lack information. Delbecq, Van de Ven, and Gustafson (1975) specifically indicate that the Delphi technique can be used for achieving the following objectives: 'a) To determine or develop a range of possible alternatives; b) To explore or expose underlying assumptions or information leading to different judgments; c) To seek out information which may generate a consensus on the part of the respondent group; d) To correlate informed judgments on a topic spanning a wide range of disciplines; e) To educate the respondent group as to the diverse and interrelated aspects of the topic.'

Delphi, in contrast to other data gathering and analysis techniques, employs multiple iterations designed to develop a consensus of opinion concerning a specific topic. Ludwig (1997) indicates, 'Iterations refer to the feedback process. The process was viewed as a series of rounds; in each round every participant worked through a questionnaire which was returned to the researcher who collected, edited, and returned to every participant a statement of the position of the whole group and the participant's own position. A summation of comments made each participant aware of the range of opinions and the reasons underlying those opinions'. Other notable characteristics inherent with using the Delphi technique are the ability to provide anonymity to respondents, a controlled feedback process and the suitability of a variety of statistical analysis techniques to interpret the data (Dalkey 1972; Ludlow 1975; Hsu, Sandford 2007). Additionally, the issue of confidentiality is facilitated by the geographic dispersion of the subjects as well as the use of electronic communication such as e-mail to solicit and exchange information (Hsu, Sandford 2007).

\section{III-IV. Modeling of inquiries and survey initiation.}

Theoretically, the Delphi process can be continuously iterated until consensus is determined to have been achieved (Hsu, Sandford 2007). Usually, there are 
from two to four iterations. However, Cyphert and Gant (1971), Brooks (1979), Ludwig (1997), and Custer, Scarcella, and Stewart (1999) point out that three iterations are often sufficient to collect the required information and to reach a consensus in most cases.

This investigation was organised with two rounds of iterations. In the first round, the Delphi process traditionally begins with an open-ended questionnaire (Hsu, Sandford 2007). Experts were asked to write all reasons, according to their practical knowledge, that affect personal solvency. After receiving experts' responses, the collected information was converted into a wellstructured questionnaire, which was used as the survey instrument for the next step of data collection.

In the second round, each Delphi participant received a second questionnaire and was asked to review the items summarised by the investigator based on the information provided in the first round. All reasons were put in five main groups by their origin (Table 3.2). Accordingly, Delphi panelists were asked to rate or 'rank-order items to establish preliminary priorities among them' (Hsu, Sandford 2007). Experts were asked to allocate $100 \%$ for the main reasons that affect personal solvency most (Fig. 7). In this round, consensus begins to form, and the actual outcomes can be presented among the participants' responses (Hsu, Sandford 2007).

Usually, in the third round, each Delphi panelist receives a questionnaire that includes the items and ratings summarised by the investigators in the previous round and are asked to revise his/her judgments or 'to specify the reasons for remaining outside the consensus' (Hsu, Sandford 2007). However, compared to the previous round, only a slight increase in the degree of consensus can be expected (Weaver 1971; Dalkey, Rourke 1972; Anglin 1991); therefore only two rounds of iterations were used in this research. The first and the second questionnaires are displayed in Annex $\mathrm{H}$ and Annex I.

The next steps of the investigation - (V) Processing results, (VI) Compatibility evaluation of opinions and (VII) Conclusions of investigation - are described in the following part 3.2.2.

\subsubsection{Quantitative Evaluation of Factors Determining the Level of Non-Performing Loans in Retail Banks}

Experts were interviewed separately by e-mails in order to avoid influence by authorities. Results were processed using logical and mathematical techniques. All the reasons that experts pointed out in the first round, were grouped by their origin (Table 3.2). 
Table 3.2. Insolvency reasons by origin (created by author according to the results of the expert evaluation)

\begin{tabular}{|c|c|}
\hline $\begin{array}{c}\text { Insolvency group by } \\
\text { origin }\end{array}$ & Insolvency reasons by experts \\
\hline Income level & $\begin{array}{l}\text { Decrease of relative income level because of increased } \\
\text { number of family members (birth of a child); } \\
\text { Reduction in number of income recipients; } \\
\text { Decreased income due to the family devorce. }\end{array}$ \\
\hline $\begin{array}{l}\text { Lack of finance man- } \\
\text { agement skills }\end{array}$ & $\begin{array}{l}\text { Inability to assess the real costs of the loan; } \\
\text { Inability to assess the loan conditions adequately; } \\
\text { Lack of financial management knowledge and skills; } \\
\text { Overdraft of credit card limit in order to finance dispensable } \\
\text { needs, such as luxury clothes, parties, holidays, travels, etc. }\end{array}$ \\
\hline $\begin{array}{l}\text { Irrational } \\
\text { behavior }\end{array}$ & $\begin{array}{l}\text { Consumption without plan; } \\
\text { Inability to plan one's needs adequately; Consumption } \\
\text { volume is not harmonized with real financial potential; } \\
\text { Spontaneous consumption and frequent, unplanned pur- } \\
\text { chases; } \\
\text { Irrational consumption; } \\
\text { Living beyond one's financial possibilities; } \\
\text { No analysis of consumption alternatives; } \\
\text { Ignoring of cheeper purchases; } \\
\text { Excessive volumes of financial liabilities; } \\
\text { Lack of responsibility and sense of duty; } \\
\text { Shopoholism (addiction to shoping); } \\
\text { Dependence on gambling; } \\
\text { Harmful addictions (alcohol, smoking). }\end{array}$ \\
\hline Force majeure & $\begin{array}{l}\text { Job loss; } \\
\text { The economic crisis in the country; } \\
\text { Illness; } \\
\text { Death; } \\
\text { Accidents (car crash, etc.); } \\
\text { Fire; } \\
\text { Injury leading to full or a long-term incapability; } \\
\text { Property loss due to accidents. }\end{array}$ \\
\hline Other if appropriate & $\begin{array}{l}\text { Young age; } \\
\text { Not formed or immature personality; } \\
\text { Lack of education; } \\
\text { Divorce; } \\
\text { Liberal (risky, incautious) lending conditions; } \\
\text { Creditor unflexibility in unforseen circumstances; } \\
\text { Inflation; } \\
\text { The increase of unemployment. }\end{array}$ \\
\hline
\end{tabular}




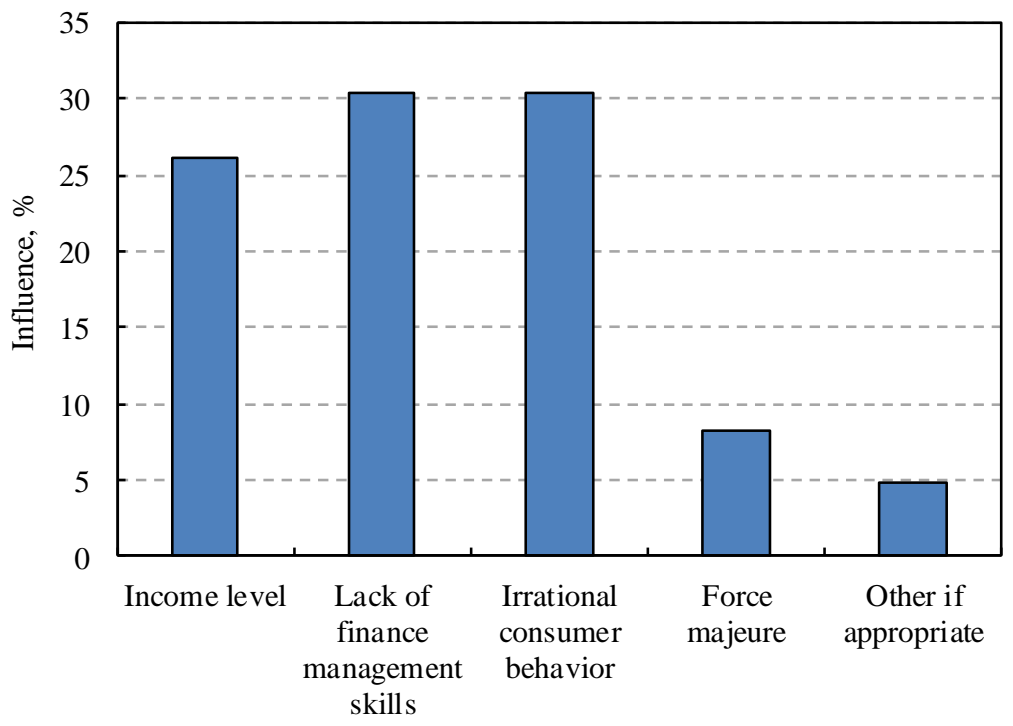

Factors

Fig. 3.4. The results of expert evaluation (source: author)

In the second round, experts quantitatively evaluated reason groups by sharing between them the total $100 \%$ weight (Fig. 3.4).

The study shows that the solvency of individuals is not highly influenced by overall economic factors - income level or force majeure, such as death, health problems, or other misfortunes. Results closely correlate with findings by other research studies: for instance, M. Keese (2009). Anderloni L. and Vandone D. (2010) have also stated that the presence of insolvency does not correlate with income. Higher income does not guarantee on time debt payments. Christelis D. et al. (2010) claim that 'even those households that are wealthy and have higher income than average are still facing difficulties fulfilling their obligations'.

Interviewed experts have clearly linked the performance of bank clients with their personality - finance management skills (30.42\%) and the way they behave as consumers $(30.46 \%)$. This means that an individual's solvency, by more than $60 \%$, depends on factors, which can be influenced and controlled by means of relevant education and training promoting rational behaviour by raising his financial and consumer awareness and developing the related skills. Providing people with access to relevant education might help to improve the pattern of consumer behaviour of individual bank clients and the situation with bad loans. 
The credibility of the performed evaluation was verified by analysing the dispersion of expert opinions and estimating concordance by using Kendall's method.

The dispersal of expert opinions is illustrated in Figure 3.5:

- Income level: a) the range amplitude from $9 \%$ to $50 \%$; b) the most frequent score (mode) - 10\%; c) median $-25 \%$; d) mean $-26.1 \%$.

- Lack of finance management skills: a) the range amplitude from $11 \%$ to $50 \%$; b) mode $-40 \%$; c) median - 30\%; d) mean $-30.4 \%$.

- Irrational consumer behaviour: a) the range amplitude from $10 \%$ to $50 \%$; b) mode $-35 \%$; c) median $-30 \%$; d) mean $-30.5 \%$.

- Force majeure: a) the range amplitude from $1 \%$ to $20 \%$; b) mode $-10 \%$; c) median $-10 \%$; d) mean $-8.2 \%$.

- Other factors: a) the range amplitude from $0 \%$ to $20 \%$; b) mode $-0 \%$; c) median $-0.5 \%$; d) mean $-4.8 \%$.

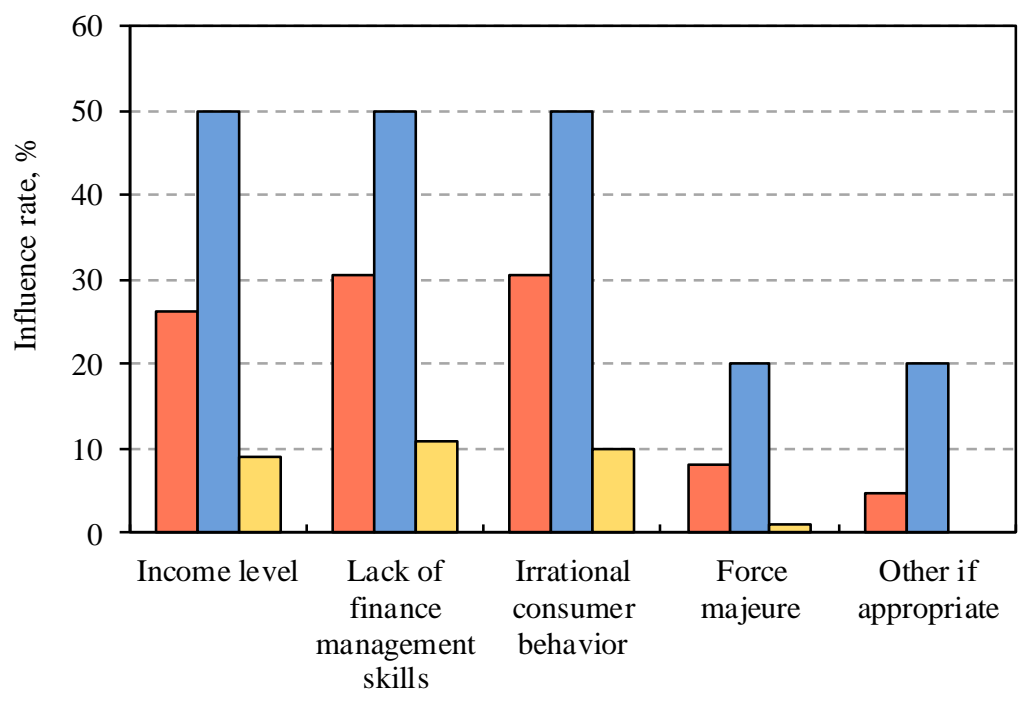

Factors

$\square$ Average value $\square$ Max value $\square$ Min value

Fig. 3.5. Minimum, maximum and average values of expert evaluation (source: author)

In order to calculate the Kendall concordance coefficient, all results were ranked from 1 to 5 , so that the maximum score would rank 1 and minimum -5 . The coefficient may range from 0 to 1 , where 1 means that all experts evaluated 
the attribute equally, while zero means that there is no link between the estimates received from different experts. The concordance coefficient was calculated by using the following formula (Rudzkienè 2014):

$$
\begin{gathered}
W=\frac{12 S^{2}}{m^{2}\left(k^{3}-k\right)}, \\
S^{2}=\sum_{j=1}^{k}\left(\sum_{i=1}^{m} x_{i j}-a\right)^{2},
\end{gathered}
$$

where $X_{i j}$ - the estimate of expert $x$ according to factor $j, m$ - number of experts, $n$ - number of factors.

In this case, we have 24 experts and 5 alternatives. Two outcomes of analysis are possible: $\mathrm{H}_{0}$ : contradictory expert assessments (i.e. concordance coefficient $W$ is zero: $W=0$ ) and $\mathrm{H}_{\mathrm{A}}$ : expert assessments are similar (i.e. concordance coefficient $W$ is not equal to zero: $W \neq 0$ ).

In this case, we have calculated that the Kendall concordance coefficient is equal to:

$$
W=\frac{12 * 3787}{24^{2}\left(5^{3}-5\right)}=0.65
$$

The significance of the concordance coefficient can be checked by applying $\chi^{2}$ criterion.

Dimension $W^{*} m *(k-1)$ has a $\chi^{2}$ distribution with $f=k-1$ degrees of free$\operatorname{dom}(m-$ number of experts, $k$ - number of factors):

$$
\begin{gathered}
W * m *(k-1)=0.65 * 24 * 4=62.4, \\
f=k-1=5-1=4 .
\end{gathered}
$$

According to the $\chi^{2}$ distribution with $\alpha$ level of critical values table, when $f=$ 4 and $\alpha=0.05$, the critical value is 9.488 (if $\alpha=0.025$, the critical value is 11.143 ; if $\alpha=0.01$, the critical value is 13.277).

As the calculated statistics $W \times m \times(k-1)$ value of the selected significance level $\alpha$ and the number of degrees of freedom $f$ exceeds the critical value, the results of expert evaluation can be accepted as reliable. 


\subsection{Modelling of a System to Guide the Aggregate Monetary Flows Originating from Consumption Expenditure}

\subsubsection{Pay-Back Potential from Investment Into Financial and Consumer Awareness Raising of Bank Clients}

The performed expert evaluation suggests that on average up to $60 \%$ of losses because of bad loans are sensitive to financial and consumer behaviour of commercial bank clients. Therefore, raising financial and consumer awareness might help decrease the amount of losses. On the other hand, implementation of measures towards this would have own cost, which would boost the losses. The aim of further analysis is to find if investment into such measures can be profitable for commercial banks and if so, what volume of investment should be targeted at.

The effect of raising economic and consumer awareness of bank clients can be calculated by simultaneously solving the following system of equations:

$$
\left\{\begin{array}{l}
L_{B L}-\text { const } \\
E(h)=C_{E} * h \\
G(h)=k * L_{B L} * \ln (h) * \frac{1}{\ln \left(h_{\max }\right)}
\end{array},\right.
$$

where $L_{B L}$ - constant variable expresses loss of commercial banks because of bad loans issued to individual clients without investment in training of bank clients;

$E(h)-$ cost of financial and psychological education, EUR; $h-\left\{0 \div \mathrm{h}_{\max }\right\}$ duration of training courses in hours; Total training cost per hour $C_{E}=C_{c l} * W /$ $n_{c l}$, where $C_{c l}-$ cost of training per class per hour; $W$ - total number of trainees; $n_{c l}-$ number of trainees per class;

$G(h)$ - gain from investment into education; $k-\{0 \div 1\}$ coefficient indicating the share of losses, which are education-sensitive; $\ln (h)$ - denotes law, which expresses the speed of knowledge perception by trainees; $\ln \left(h_{\max }\right)$ - a constant, which transforms absolute numbers into relative.

Aggregate loss of banks after investment into education can be expressed as follows:

$$
L_{\Sigma}=L_{B L}+E(h)-G(h)=L_{B L}+C_{E} * h-k * L_{B L} * \ln (h) * \frac{1}{\ln \left(h_{\max }\right)},
$$


The real values of $L_{\Sigma}$ calculated for various $L_{B \mathrm{~L}}(10,20,30$ and 40 million EUR), $C_{c l}=60$ EUR, $n_{c l}-30, W-50000$ and $k=0.7$ in reference to duration $h$ of education of bank clients are presented in Figure 3.6, while Figure 3.7 displays them in reference to estimated education cost.

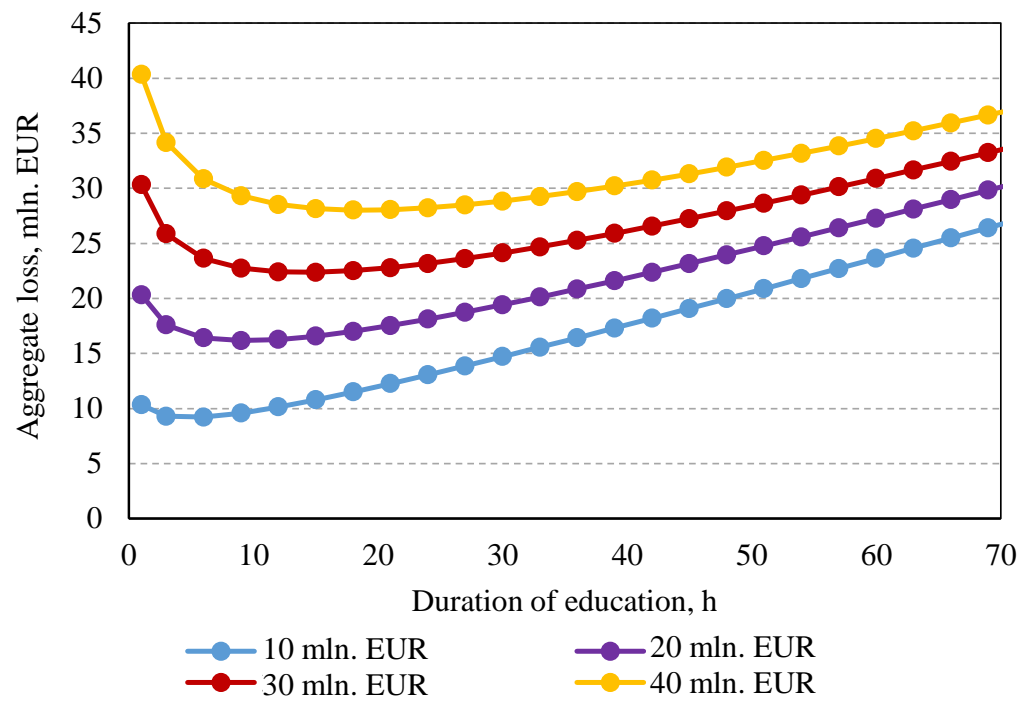

Fig. 3.6. Effect of education on aggregate loss of banks caused by non-performing loans $\mathrm{L}_{\mathrm{BL}}=10,20,30$ and 40 million EUR (source: author)

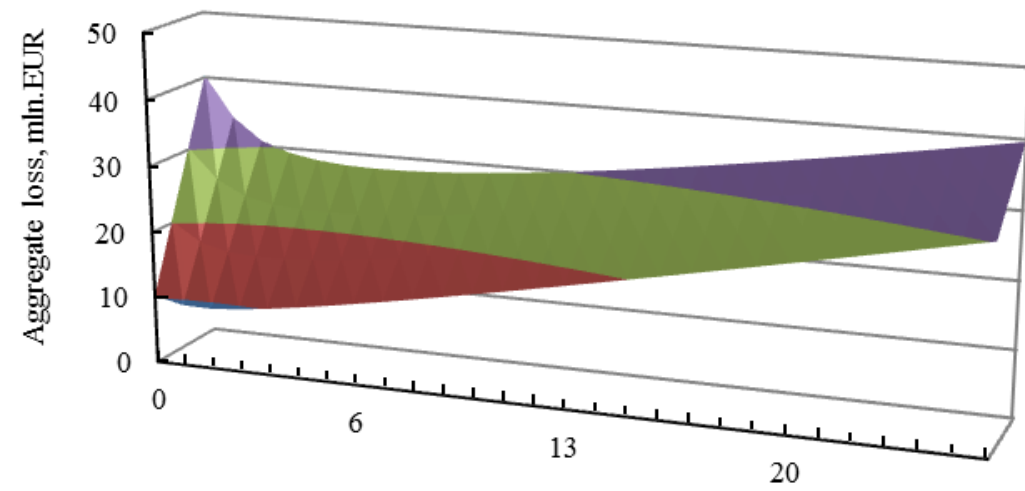

Investment in education, mln EUR

Fig. 3.7. Effect of investment in education on bank losses caused by non-performing loans (source: author) 
As the curves in Figure 3.7 presenting aggregate loss contain extrema, an expression of optimal duration of education $h$ can be found by applying the derivative tests for $L_{\Sigma}$ equation:

$$
\begin{gathered}
\frac{\partial L_{\Sigma}}{\partial h}=\frac{\partial L_{B L}}{\partial h}+\frac{\partial\left(C_{E} * h\right)}{\partial h}-\frac{\partial\left(k * L_{B L} * \frac{\ln (h)}{\ln \left(h_{\max }\right)}\right)}{\partial h}=0+C_{E}-\frac{1}{h} * \frac{k * L_{B L}}{\ln \left(h_{\text {max }}\right)}=0, \\
h=\frac{k * L_{B L}}{C_{E} * \ln \left(h_{\max }\right)}=\frac{k * L_{B L} * n_{C l}}{C_{C l} * W * \ln \left(h_{\max }\right)}, \\
E=\frac{k * L_{B L}}{\ln \left(h_{\text {max }}\right)} .
\end{gathered}
$$

By inserting the appropriate values of $\mathrm{k}, L_{B L}, n_{c}, C_{c l}, W$ and $h_{\max }$, an optimal duration of training can be calculated as well as the related cost.

The problem of loss control in commercial banks is urgent not only in Lithuania but also in commercial banks of other countries as well.

Figure 3.8 illustrates the dynamics of risk provision in commercial banks of Western and Eastern Europe in the years 2007-2014. It shows that the level of provisions has been changing in the range of $10-23 \%$.

As the above calculations show, through restructuring of resources, banks could employ certain amounts for the improvement of performance of their clients. Significant reserves definitely exist in the disposition of banks, which could be used for this purpose.

Western Europe (2007=100)

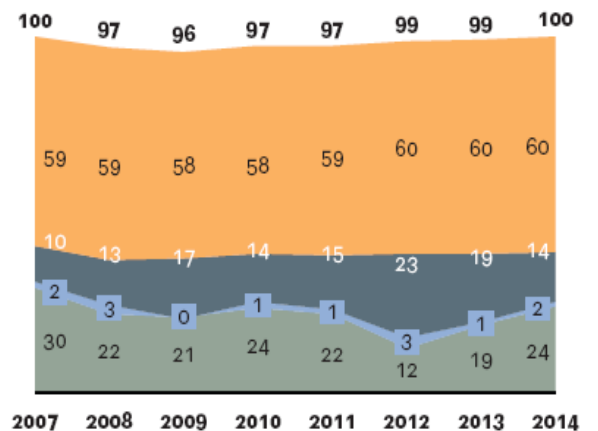

\section{Eastern Europe $(2008=100)$}

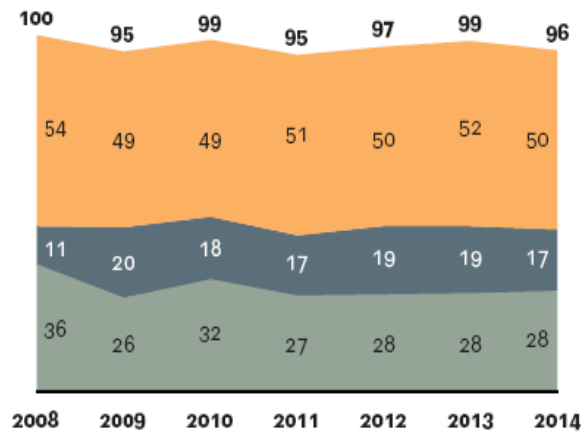

Operating expenses

Risk provisions
Profit before tax

Fig. 3.8. Profitability and risk provisions of commercial banks in East and West Europe (Pratz et al. 2015). 


\subsubsection{Current Setup of Collaboration between Retail Banks and Households and Existing Shortcomings}

Current collaboration between households and commercial banks is based on formal agreements between them with the focus on fulfilment of mutual obligations. Some changes took place in the cooperation setup during the recent years as a result of deteriorating borrower performance of households triggered by the financial crisis of 2008-2010. The cooperation became less formal compared to the previous; some free-of-charge services were offered to bank clients, including consultancy and limited-scale informal education within personal finance management and financial awareness raising related to products offered by commercial banks, saving and investment (see Table 3.4).

Table 3.4. The framework of current cooperation between commercial banks and individual clients in Lithuania (source: author)

\begin{tabular}{|c|c|}
\hline $\begin{array}{l}\text { Current collabora- } \\
\text { tion between banks } \\
\text { and individual cli- } \\
\text { ents emmerged } \\
\text { during the post- } \\
\text { crisis period }\end{array}$ & Shotcomings of the existing collaboration \\
\hline $\begin{array}{l}\text { Financial educa- } \\
\text { tion concept for } \\
\text { years 2012-2016 } \\
\text { developed by the } \\
\text { Bank of Lithuania }\end{array}$ & $\begin{array}{l}\text { The concept is poorly visible in public, unless the bank clients are } \\
\text { specifically interested in it and actively seek to find information. Ed- } \\
\text { ucation program mainly focuses on awareness raising within prod- } \\
\text { ucts and services offered by banks and doesn't cover the manage- } \\
\text { ment of consumption expenditure, which actually determines the } \\
\text { flow of financial resources in households by more than } 98 \% \text {. }\end{array}$ \\
\hline $\begin{array}{l}\text { Commercial } \\
\text { banks' specialized } \\
\text { units and websites } \\
\text { focused on finan- } \\
\text { cial education }\end{array}$ & $\begin{array}{l}\text { Financial information available in commercial bank units and } \\
\text { websites is associated with awareness raising within the wide } \\
\text { range of banking products, for example, the difference between } \\
\text { credit and debit cards, different types of loans, methods on how } \\
\text { to calculate interests and so on, but no information about daily } \\
\text { consumption expenditure management aspects. }\end{array}$ \\
\hline $\begin{array}{l}\text { Personal bankers' } \\
\text { services in com- } \\
\text { mercial banks }\end{array}$ & $\begin{array}{l}\text { Personal bankers consult about funds management, investment is- } \\
\text { sues and financial planning in the context of life-cycles, but does not } \\
\text { advice on budgetary performance and the utility optimisation issues. } \\
\text { Besides, the personal bankers }{ }^{6} \text { services usually are dedicated for cli- } \\
\text { ents with high-income level that look for personalized attention and } \\
\text { exclusive financial products. }\end{array}$ \\
\hline $\begin{array}{l}\text { Free access to rele- } \\
\text { vant financial in- } \\
\text { formation in public } \\
\text { domain }\end{array}$ & $\begin{array}{l}\text { The market offers a lot of tools, including free-of-charge for personal } \\
\text { finance management. Most of them are directed towards the alloca- } \\
\text { tion of funds for current and future consumption, but are not applica- } \\
\text { ble to control of resources on elementary purchases level. }\end{array}$ \\
\hline
\end{tabular}


The significant increase in the non-performing loan level during the crisis has caused a dramatic raise of commercial bank losses and forced them to draw attention to closer cooperation with households. However, the majority of steps undertaken by banks so far, which are listed in Table 3.4, mainly target the consequences by providing consultancy to the clients already facing problems, but no attempts were undertaken to understand what the main reasons of these problems are. In addition, there are independent financial consultants operating in the financial services market. The majority of financial consultants provide advice on wealth management, investment, saving, and financial security aspects. Some consult about cost-cutting issues, and guide clients to the selection of low-cost goods and consumption restriction, usually leading to the impoverishment of the quality of life. Such consultations have no relationship with harmonised consumption that could lead to financing an individual's needs according to current budget limits.

Despite changes, the current state of collaboration between commercial banks and households is not adequate to contemporary challenges that households and retail banks face and both would be willing to avoid. This makes a good base for their joint activity towards the improved efficiency of finance management in households.

Currently, the control of financial resources in households, especially its part intended for consumption, can be characterised as being under strong influence of advertising media in the product market. No adequate information is available in the media to support rational consumption in households. If a supermarket announces sales, this information is being spread across the society immediately, but no information is available on how to rationally behave and avoid purchasing of items, which the consumer does not necessarily need. The imbalance between the two flows of information, first aimed at encouraging consumption and second aimed at promoting rational consumer behaviour, is obvious in both the volume and efficiency. The resources used to create these flows stand behind this imbalance and result in extremely unfavourable for retail banks distribution of households' monetary flows. Any measures to make these flows more balanced should be in favour of not only retail banks, but also of households.

This imbalance makes the efforts of commercial banks to promote their services and increase the turnover not efficient. The attitude of commercial banks looks in this context to be kind of old-fashioned and inefficient. Statistics of the retail banking market show that in 2014 the volume of loans issued to individuals in Lithuania amounted to 6.6 billion EUR and the total number of loans reached $0.86 \mathrm{mln}$. Thirty-eight per cent of them were consumer loans, $21.3 \%$ mortgages, $4.3 \%$ lease agreements and $36.1 \%$ all the rest. Non-performing loans made $6.4 \%$; therefore, loss on interest only at an average $3.5 \%$ interest rate, made 14.7 mln EUR, while the maximum loss in the case of full insolvency of clients 
would make $452 \mathrm{mln}$ EUR. Thus, an expected loss at the current NPL rate of $6.4 \%$ would range from the minimum of $14.7 \mathrm{mln}$ to a maximum of $452 \mathrm{mln}$ EUR, which make accordingly $6 \%$ and $180 \%$ of the usual annual profit of all the retail banks of Lithuania. This shows that a need for improvement of managing the efficiency of financial resources in households definitely exists, while commercial banks are the ones to have high interest in this.

The banks could more actively promote not only financial literacy among their clients, but first of all rational consumer behaviour with the aim of reaching a more favourable balance between monetary flows in the product and retail banking markets. The present relative ratio between them, being up to 3-5 times lower than in countries with advanced economies, is extremely unfavourable for the retail banking in Lithuania. Changing this ratio should be considered by commercial banks as an opportunity for improvement of their performance. Adequate steps to change the situation should be undertaken, including the modification of the attitude of banks towards individual clients, which should become more open, less formal, with a focus on raising of their financial and consumer awareness.

\subsubsection{A System for Guidance of Consumption-Related Monetary Flows based on Modified Collaboration between Households and Retail Banks}

The idea behind the modification of current collaboration between retail banks and households is a creation of conditions for more efficient control of household financial resources used for consumption on both the elementary purchases level and the level representing aggregate countrywide monetary flow. The first level is important, first of all, for each household and its budgetary performance while the second one is crucial for the performance of the entire retail banking market (See 'goals' in Figure 3.9). Modified collaboration should make ground for creation of a system promoting more efficient control of household resources on both levels. The specified goals can be achieved through creation of an infrastructure for specific education of bank clients. A specific feature of the education is the dissemination of ideas and methods enabling rational use of household resources by applying the formal decision-making procedures developed in Chapter 2 . Formalization of the decision-making process eliminates the influence of various subjective factors having psychological origin and makes the decisions more transparent due to employed quantitative evaluation criteria. The diagrams presenting the overall interactions between the collaborating parties - retail banks and households - and benefits provided to them are shown in Figure 3.9. Diagrams disclose the objectives each of the partners seeks. 


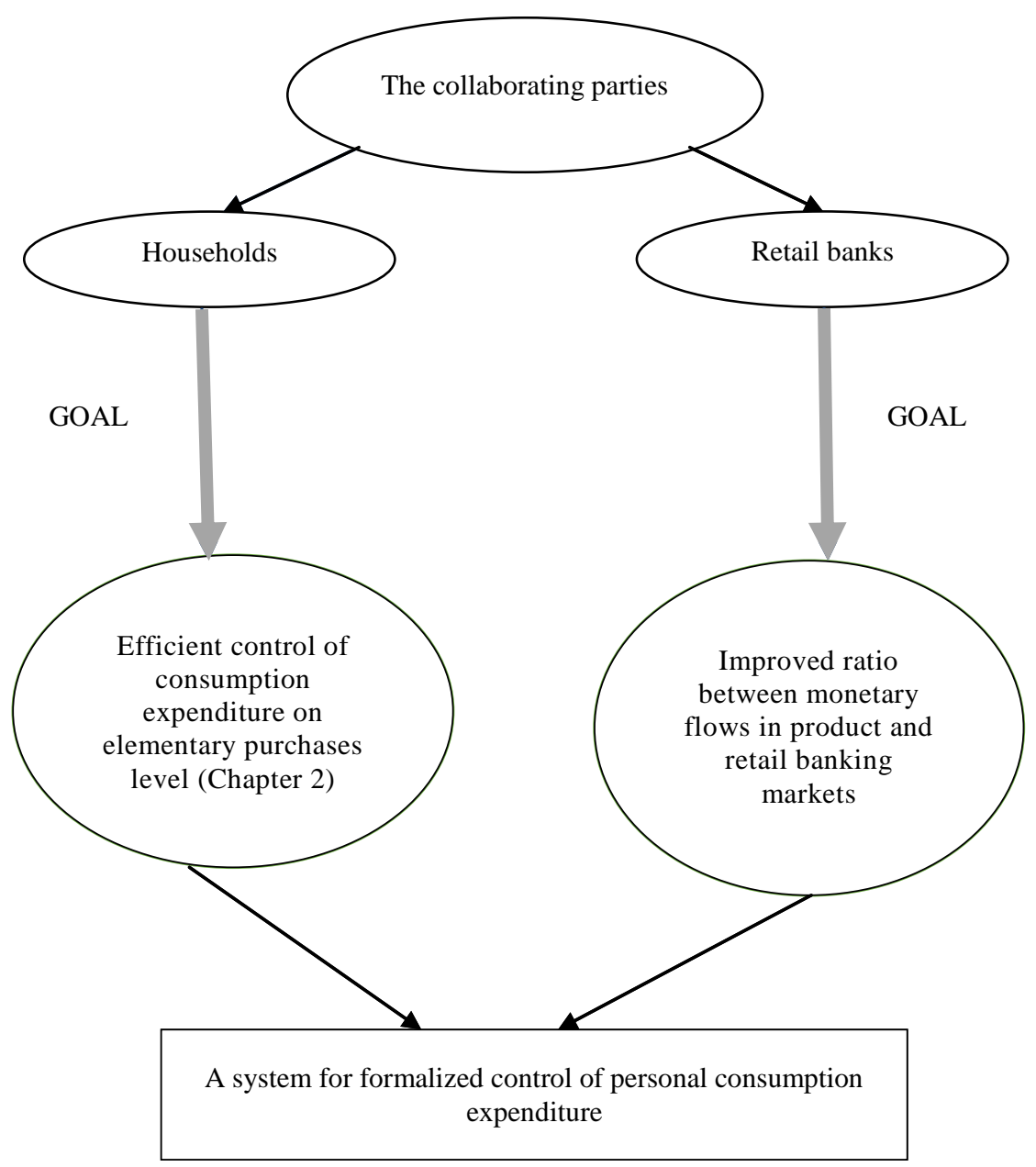

Fig. 3.9. Collaborating parties in the system (source: author)

Fig. 3.10 shows how the education program of bank clients is composed and what the targets of it are. Comments and explanations about specific courses taught in both the financial-economic and psychology segments are shown in Annex E. The courses are composed following the personal finance management program, taught in universities, but modified to match the average knowledge, skills and capabilities of bank clients. 


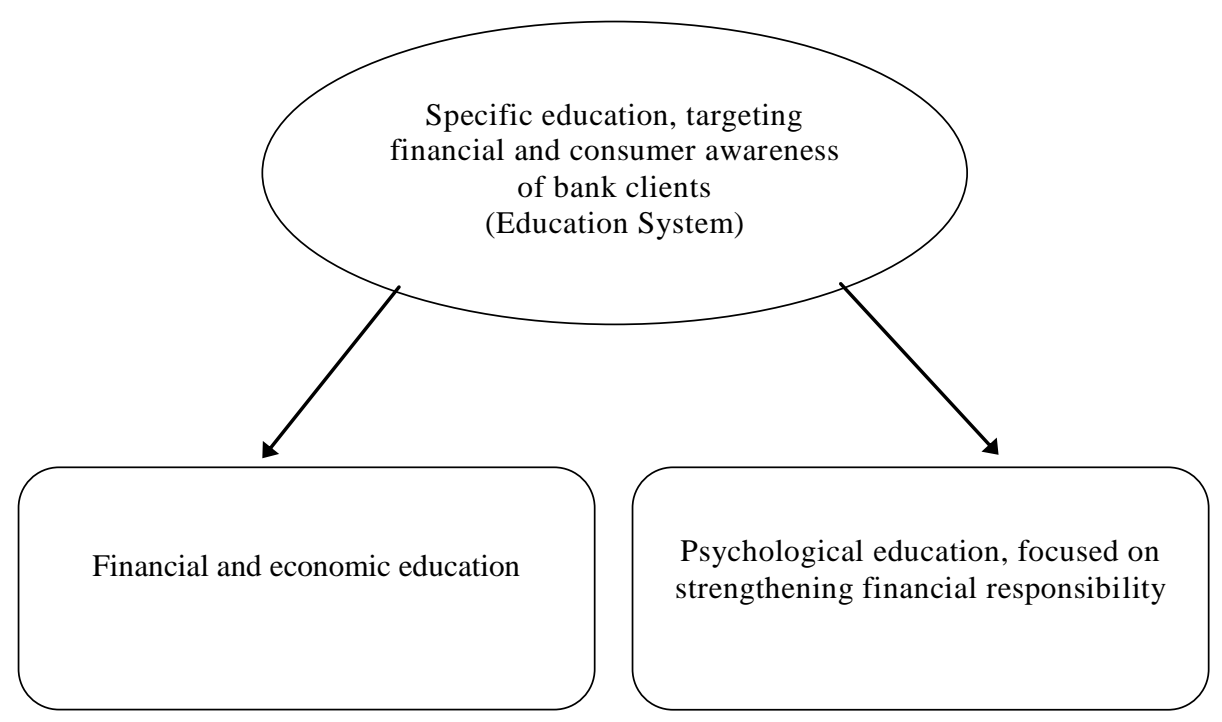

Fig 3.10. The structure of the education program of bank clients (source: author)

The whole system for formalized control of personal consumption expenditure containing elements developed in this study is displayed in Figure 3.11. Both elements play their own role in the system and serve for improved control efficiency of household consumption expenditures on elementary purchases and the aggregate monetary flow levels. Following the idea of modified cooperation between households and retail banks, the banks are encouraged to invest in the development of the education infrastructure and financially support its operation. As shown in the diagram in Fig. 3.11, monetary flows on the aggregate flow level are not under direct control of the system, but they are affected indirectly and guided through the influence of financial and consumer behaviour of bank clients as a result of raised financial and consumer awareness. The effect of the system, as it follows from the above comments, is twofold (the grey arrows in Fig. 3.9). First, the benefits can be explored by households from improved management efficiency of everyday consumption and, secondly, from the expected shift of monetary flows from the product market over to the retail banking market. The latter indicator in the countries with advanced economies is several times higher than in Lithuania (1-2\% compared to 6-11\%); therefore, a significant increase in turnover should be expected. 

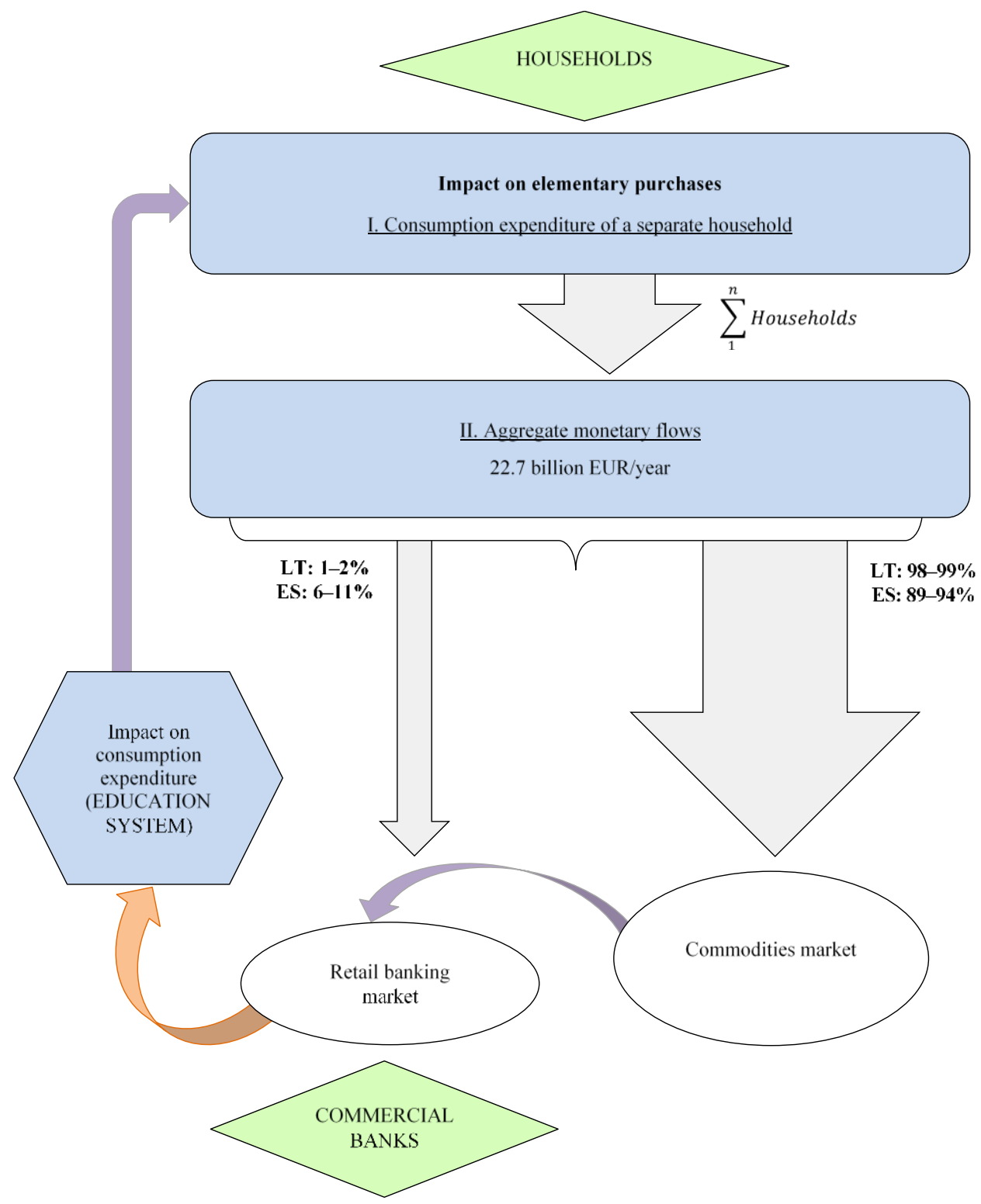

Fig. 3.11. Model of formalized system to control personal consumption expenditure (source: author)

Even the most conservative evaluation of the payback potential of investment into the system, which was performed in section 3.3.1, shows good payback possibilities. If the effect from the total loss of solvency (bankruptcy) of clients and the 
expected increase of turnover in the retail banking market are added, the prognosis is even more optimistic. There are no other reasons except for those highlighted in this research to justify the dramatic difference in the volume of the retail banking market in Lithuania compared to other countries. If the system is implemented, the retail banking market indicators in Lithuania should become more consistent with those in other countries and should add to the significant improvement of performance of commercial banks.

\subsection{Conclusions of Chapter 3}

1. Limited revenue generated from household related monetary flows and imperfect quality of loan portfolios have negative effects on the performance of commercial banks. As processes in commodity market segments clearly dominate (in terms of volume), they should be regarded as important for business specifically in the retail banking market. This suggests that banks should act adequately and adjust their strategies, identifying themselves as players in the entire market and compete with other players for their stake from the aggregate household-related monetary flows.

2. Observed similarity suggests that a close correlation between the budgetary and borrower performance of households might exist with a possibly strong link of both with the pattern of consumer behaviour. This makes the banks and households natural partners equally interested in the improvement of control efficiency of households ${ }^{6}$ financial resources.

3. A variety of factors influence the risk related to individuals' borrowing and solvency. To systemise and evaluate the impact of various factors on risky loans, they were classified into groups based on their impact on households' financial flows:

- Direct, having monetary dimension and direct impact on households' financial flows (e.g. change of income level).

- Indirect, which affect the individual's financial flows indirectly and cannot be defined in a monetary form (e.g. gender, age, place of residence, purpose of the loan etc.).

4. The performed expert evaluation revealed that up to $60 \%$ of nonperforming loans issued to individuals might depend on the consumer and financial awareness of the clients. Both could be improved by means of specific education, where traditional financial education is supplemented with knowledge in economics and especially in 
psychology. Involvement of banks in the education of clients could be beneficial for commercial banks themselves as this might positively affect the efficiency of finance management in households.

5. Commercial banks are encouraged to modify their existing cooperation with households by developing an infrastructure for the education of their clients. A model for evaluation of payback potential of investment into development of this infrastructure and financial support of education was developed. Modelling results based on real data from the retail banking market indicates good payback possibilities.

6. Characterisation of bank clients by using only income level indicators is not sufficient. Not only clients' financial awareness, but first of all their consumer behaviour should be taken into account by commercial banks as consumption by more than $98 \%$ determines the flow of household-related financial resources. 



\section{General Conclusions}

1. Household expenditure in Lithuania accounts for approximately $2 / 3$ of the GDP; therefore, its efficient management is of high importance for a country's performance in both microeconomics and macroeconomics segments. The distribution of householdrelated financial flows between consumer and financial services markets shows that only $1-2 \%$ from that amount constitutes the revenue of commercial banks, while $98-99 \%$ is used for the purchase of goods and non-financial services, which indicates the dominating role of the latter market.

2. The management efficiency of household-related financial flows affects the budgetary performance of households and performance of those commercial banks that have business co-operation with them. Research on Lithuanian households has revealed that a significant part of them (30-40\%) permanently suffer from a budget deficit, irrelevant of income level and showed that households face serious finance management problems. Consequently, this results in a high level of non-performing loans issued by commercial banks to individual clients. This level, which has reached its peak of $25 \%$ in 2010, has caused significant losses in retail banking, and it took approximately five years for commercial banks to recover. Similar 
problems are urgent not only in Lithuania, but also in countries with relatively wealthy average households (e.g. Greece, Italy, Spain, Portugal, Iceland, Cyprus and many others).

3. Analysis of the poor budgetary performance of households indicates weak or almost no correlation with the income level. Reasons, which compromise finance management efficiency in households, are complex and depend on the one hand on limited ability to rationally act in consumer markets due to certain personal features and an inability to limit the influence of various subjective factors on financial decisions and, on another hand, due to limited support from the economics theory side, which lacks methods and tools supporting rational consumer behaviour. Historical analysis of theories and research studies within consumer behaviour has revealed that certain gaps definitely exist in economic theories, first of all within control of everyday spending, which at the end forms the aggregate consumption-related financial flows.

4. Neither economic or psychological theories, nor contemporary combined theories were able to provide the needed answers so far. Still, the majority of everyday decision-making motives are totally up to subjective consumers' opinion, and no formalized procedures exist to limit influence of those subjective factors; therefore, the current situation with the budgetary performance of households can be considered as a natural consequence of existing decision-making technologies. The current management of financial resources intended for consumption is best characterised when it is compared with a car that drives on the road with many speed limit signs, but which does not have a speedometer, in other words, 'financial cars of households in reality drive without speedometers', which result in irrational financial decisions in the field of consumption.

5. In order to fill the existing gap, the theoretical principles of a new combined economic-psychological approach to the management of households' expenditure, containing a pre-purchase matchmaking stage have been proposed. The key element of the approach is the decomposition of the aggregate value of goods/services into components, each reflecting a certain level of Maslow's pyramid of needs, and enabling their matching with the corresponding set of components, which represent the consumer's preferences. Thus, consumer preferences, having both physiological and psychological origin, are projected onto the aggregate value of goods/services and integrated with their economic (price) indicators. 
6. The proposed approach makes it possible to quantitatively evaluate and compare the value components representing different levels of the Maslow pyramid of needs and estimate the respective cost of a consumer's needs/wishes. Case studies in microeconomics and macroeconomics segments have proved the validity of the approach and its potential in being applied as a planning tool in managing households' expenditure. Reduced dependence on subjective decisions limits spontaneous spending, gives the possibility of harmonising not only total/aggregate consumption with income, but also to find a balance between every item in the bunch of products/services purchased, thus preventing an unbalanced (excessive or insufficient) allocation of funds for consumption, which distinguishes the developed approach from existing.

7. Observed similarity suggests that a close correlation between the budgetary and borrower performance of households might exist with a possibly strong link of both with the pattern of financial and consumer behaviour. This has served as a base for the formulation of a major working hypothesis in the research, stating that commercial banks should change their attitude towards households and closely co-operate with them in order to improve the performance of both.

8. The results of research, during which the bank experts were interviewed, show that up to $60 \%$ of non-performing loans issued to individuals might depend on the personality (or the pattern of consumer behaviour) and financial awareness of clients. Both could be improved by means of specific financial, economic and psychological education. Involvement of banks in the education of clients could be beneficial for commercial banks themselves as this might positively affect the efficiency of finance management in households. A method for the evaluation of payback potential from investment into education was developed.

9. Based on the research results obtained, the following recommendations for commercial banks were developed:

- Commercial banks should consider processes in consumer markets as important for their activities and performance. The banks should compete for the financial flows of households with the sellers of goods and non-financial services, while households should be treated as natural partners of the banks.

- The characterisation of bank clients by only using the income level indicators is not consistent. Not only the income 
and financial awareness of clients, but first of all their consumer behaviour should be taken into account as this by more than $98 \%$ determines the flow of households' financial resources.

- Banks should consider participation in the education of their clients as an opportunity of investing in improvements of their performance by improving consumption-related finance management skills in households.

- Development of a consumption expenditure management system, based on modified co-operation between commercial banks and households, including an education system of bank clients using the developed formalized consumption management approach, might be an efficient way to reduce the negative effect of non-performing loans on the performance of commercial banks. 


\section{References}

Abreu, M.; Mendes, V. 2010. Financial Literacy and Portfolio Diversification, Quantitative Finance 10(5): 515-528. doi: 10.1080/14697680902878105.

Alfaro, R.; Gallardo, N. 2012. The Determinants of Household Debt Default, Revista de Análisis Económico 27(1): 55-70.

Almenberg, J.; Gerdes, Ch. 2012. Exponential Growth Bias and Financial Literacy, Applied Economics Letters 19(17):1-8. doi: 10.1080/13504851.2011.652772.

Altfest, L. 2009. Personal Financial Planning: Origins, Developments and A Plan for Future Direction, The American Economist 48(2): 53-60.

Anderloni, L.; Bacchiocchi, E.; Vandone, D. 2012. Household financial vulnerability: an empirical analysis, Research in Economics 66: 284-296.

Anderloni, L.; Vandone, D. 2010. Risk of overindebtedness and behavioural factors. In: Lucarelli, C., Brighetti, G. (Eds.), Risk tolerance in financial decision.

Anglin, G. L. 1991. Instructional technology past, present and future. Englewood, CO: Libraries Unlimited Inc.

Ansari, M. 2000. Economic Rationality: An Evaluation, Journal of Assam University 5(1): 1-12.

ANZ/The Social Research Center [online]. 2011. Adult Financial Literacy in Australia. ANZ Survey [cited 12 May 2015]. Available from Internet: http://www.anz.com/resources/f/9/f9fc9800493e8ac695 c3d7fc8cff90cd/2011-Adult-Financial-LiteracyFull.pdf.pdf?CACHEID=f9fc9800493e8ac695c3d7fc8cff.

Arnold, J.; Randall, R.; Patterson, F.; Silvester, J.; Robertson, I.; Cooper, C.; Burnes, B.; Harris, D.; Axtell, C.; Hartog, D. D. 2010. Work Psychology: Understanding human behaviour in the workplace. 5th ed. London: Pitman. 
Association of Lithuanian Banks [online]. 2015. Statistics [cited 22 October 2015]. Available from Internet: http://www.lba.lt/go.php/eng/Statistics/339/4.

A.T. Kearney [online] 2015. The 2015 Retail Banking Radar. Time to Reinvent your Banking Model [cited 14 January 2016]. Available from Internet: https://www.atkearney.com/documents/ 10192/5903614/Time+to+Reinvent+Your+Banking+Model.pdf/ec08fb0d-44e8-4c83-9b5837d731515bf5.

Atkinson, A.; Messy, F. 2012. Measuring Financial Literacy: Results of the OECD/ International Network on Financial Education (INFE) Pilot Study, OECD Working Papers on Finance, Insurance and Private Pensions 1(15): 1-73. http://dx.doi.org/10.1787/5k9csfs90fr4-en.

Baek, E.; Hong, G. S. 2004. Effects of Family Life-Cycle Stages on Consumer Debts, Journal of Family and Economic Issues 25(3): 359-385.

Baranzini, M. 2005. Modigliani's life-cycle theory of savings fifty years later, BNL Quarterly Review 58(1): 109-172.

Barber, B. M.; Odean, T. 2005. Advance in Behaviour Finance, Individual Investors: Princeton University 2(1): 543-569.

Becker, G. S. 1960. An Economic Analysis of Fertility, Demographic and Economic Change in Developed Countries (1): 209-240.

Becker, G. S. 1965. A Theory of the Allocation of Time, Economic Journal 75(299): 493-517.

Becker, G. S. 1993. A Treatise on the Family. Enlarged Edition. Harvard University Press.

Beller, A. H.; Kiss, D. E. 1999. On the Contribution of Hazel Kyrk to Family Economics. In: Paper prepared for presentation at the Society for the Advancement of Behavioural Economics meeting, Exploring the Reorientation of Economics, San Diego, California, June 12-14.

Behrman, J. R.; Pollak, R. A.; Taubman, P. 1995. From Parent to Child: Inequality and Immobility in the United States. Chicago: University of Chicago Press.

Bentham, J. [online] 1789. An Introduction to the Principles of Morals and Legislation. Oxford: Clarendon Press [cited 05 July 2015]. Available from Internet: http://www.econlib.org/library/ Bentham/bnthPML1.html\#Chapter I, Of the Principle of Utility

Berger, A. J.; Mulvey, J. M. 1998. The Home Account Advisor TM, Asset and Liability Management for Individual Investors. In Ziemba, William T., and John M. Mulvey, eds., Worldwide Asset and Liability Modelling. Cambridge University Press (1): 634-663.

Bergmann, B. R. 1995. Becker's Theory of the Family: Preposterous Conclusions, Feminist Economics 1(1): 141-150.

Bernoulli, D. 1738. Exposition of a New Theory on the Measurement of Risk. Reprinted in 1954, Econometrica 22 (1): 22-36. doi:10.2307/1909829.JSTOR 1909829.

Bigda, C.; Mannes, G.; Updegrave, W. 2010. Ask the Experts, Money 39(6): 43-48. MERLOT Publishing.

Bikas, E.; Kavaliauskas, A. 2010. Lithuanian Investors' Behaviour during Financial Crisis, Verslas: teorija ir praktika [Business: Theory and Practice] 11(4): 370-380. http://dx.doi.org/10.3846/btp.2010.40.

Bishop, P. 2013. The Spatial Distribution of Personal Insolvencies in England and Wales, 20002007, Regional Studies 47(3): 419-432. http://dx.doi.org/10.1080/00343404.2011.581653.

Bodie, Z.; Kane, A.; Marcus, A. J. 2003. Essentials of Investments. Singapore: The McGraw Hill Companies. 312 p.

Bosshardt, W.; Walstad, W. B. 2014. National Standards for Financial Literacy: Rationale and Content, The Journal of Economic Education 45(1): 63-70. doi:10.1080/00220485.2014.859963. 
Bray, J. [online] 2008. Consumer behaviour theory: approaches and models [cited 10 October 2015]. Available from Internet: http://eprints.bournemouth.ac.uk/10107/1/Consumer_ Behaviour_Theory_-_Approaches_\%26_Models.pdf.

Brohmann, B.; Quack, D. [online] 2015. Smart consumption: buying with a view to sustainable benefits [cited 10 October 2015]. Institute for Applied Ecology. Available from Internet: http://www.oeko.de/en/research-consultancy/issues/sustainable-consumption/smart-consumption.

Brooks, K. W. 1979. Delphi technique: Expanding applications, North Central Association Quarterly 54(3): 377-385.

Brown, S.; Taylor, K. 2008. Household debt and financial assets: evidence from Germany, Great Britain and the USA, Journal of the Royal Statistical Society 17: 615-643.

Business Dictionary [online] 2016. 'Household' definition [cited 24 January 2016]. Available from Internet: http://www.businessdictionary.com/definition/household.html.

Business Dictionary [online] 2016. 'Systemic or system-wide' definition [cited 24 January 2016]. Available from Internet: http://www.businessdictionary.com/definition/systemic.html.

Burreau of Economics Analysis [online]. 2016. Chapter 5: Personal Consumption Expenditures [cited 16 January 2016]. Available from Internet: https://www.bea.gov/national/pdf/ nipahandbookch5.pdf.

Buskens, V. 2015. Rational Choice Theory in Sociology. International Encyclopedia of the Social \& Behavioral Sciences (Second Edition), 901-906. doi:10.1016/B978-0-08-097086-8.321778.

Cambridge Dictionaries [online]. 2016. Meaning of "Household" in the English Dictionary [cited 14 January 2016]. Available from Internet: http://dictionary.cambridge.org/dictionary/english/ household.

Campbell, J. Y. 2006. Household Finance, Journal of Finance 61(4): 1553-1604.

Carlin, B. I.; Robinson, D. T. 2012. What Does Financial Literacy Training Teach Us? The Journal of Economic Education 43(3): 235-247. doi: 10.1080/00220485.2012.686385.

Certified Financial Planner Board of Standards [online]. 2012. Household Financial planning Survey [cited 30 April 2012]. Available from Internet: http://www.cfp.net/docs/for-cfp-pros--public-awareness-campaign-toolkit/2012-household-financial-planning surveysummary.pdf?sfvrsn=0.

Christelis, D.; Jappelli, T.; Paccagnella, O.; Weber, G. 2010. Income, wealth and financial fragility in Europe, Journal of European Social Policy 19(4): 359-376.

Competition and Markets Authority [online]. 2015. Retail banking market investigation. Retail banking financial performance [cited 24 October 2015]. Available from Internet: https://www.gov.uk/government/organisations/competition-and-markets-authority.

Connoly, J.; Prothero, A. 2008. Green consumption: life-politics, risk and contradictions, Journal of consumer culture 8:117-145.

Consiglio, A.; Cocco, F.; Zenios, S. A. 2004. www.personal asset allocation, Interfaces 34: 287302.

Consiglio, A.; Cocco, F.; Zenios, S. A. 2002. Personal Asset Allocation. Working Paper in HERMES Center of Excellence on Computational Finance \& Economics, School of Economics and Management, University of Cyprus.

Consiglio, A.; Cocco, F.; Zenios, S. A. 2007. Scenario optimization asset and liability modeling for individual investors, Annals of Operations Research 152: 167-191.

Consumer Federation of America [online]. 2012. Household Financial Planning Survey [cited 15 September 2015]. Available from Internet: http://www.consumerfed.org/pdfs/Studies.CFACFPBoardReport7.23.12.pdf. 
Consumer Voice Organization [online]. 2012. Factors influencing consumer behavior [cited 21 July 2014]. Available from Internet: https://consumervoiceblog.wordpress.com/2012/08/03/ factors-influencing-consumer-behaviour/.

Corpuz, J. [online]. 2015. 10 Best Budgeting and Personal Finance Apps [cited 17 August 2015]. Available from Internet: http://www.tomsguide.com/us/pictures-story/548-best-budget-expenseapps.html

Crary, M. [online]. 2012. Budgeting Software Options [cited 13 November 2012]. Available from Internet: http://www.forbes.com/sites/moneywisewomen/2012/01/03/budgeting-software-options/ \#2ff46be3218f.

Credit Counselling Society [online]. 2016. Impulse shopping \& spending - chech your impulse [cited 14 January 2016]. Available from Internet: http://www.mymoneycoach.ca/spendingmoney/how-to-avoid-control-impulse-shopping-spending-buying.

Credit Counselling Society [online]. 2016. 7 steps to build a household budget/Money management strategies [cited 12 January 2016]. Available from Internet: http://www. mymoneycoach.ca/money-management/budgeting-plan-for-future.

Custer, R. L.; Scarcella, J. A.; Stewart, B. R. 1999. The modified Delphi technique: A rotational modification, Journal of Vocational and Technical Education 15(2): 1-10.

Cyphert, F. R.; Gant, W. L. 1971. The Delphi technique: A case study, Phi Delta Kappan 52: 272-273.

Customsight [online]. 2009. Survey Random Sample Calculator [cited 16 March 2009]. Available from Internet: http://www.custominsight.com/articles/random-sample-calculator.asp.

Dalkey, N. C. 1972. The Delphi method: An experimental study of group opinion. In N. C. Dalkey, D. L. Rourke, R. Lewis, \& D. Snyder (Eds.). Studies in the quality of life: Delphi and decision-making (pp. 13-54). Lexington, MA: Lexington Books.

Dalkey, N. C.; Helmer, O. 1963. An experimental application of the Delphi method to the use of experts, Management Science 9(3): 458-467.

Dalkey, N. C.; Rourke, D. L. 1972. Experimental assessment of Delphi procedures with group value judgments. In N. C. Dalkey, D. L. Rourke, R. Lewis, \& D. Snyder (Eds.). Studies in the quality of life: Delphi and decision-making (pp. 55-83). Lexington, MA: Lexington Books.

Dasgupta, S.; Papadimitriou, C. H.; Vazirani, U. V. [online] 2006. Algorithms [cited 24 February 2013], 161 - 181. Available from Internet: https://www.cs.berkeley.edu/ vazirani/algorithms/chap6.pdf).

Dean, M. 2009. Consumer Theory. In: Lecture Notes for Fall 2009 Introductory Microeconomics. Brown University.

Deaton, A. 1992. Understanding Consumption. Oxford University Press.

Delbecq, A. L.; Van de Ven, A. H.; Gustafson, D. H. 1975. Group techniques for program planning. Glenview, IL: Scott, Foresman, and Co.

Dempster, M. A. H.; Medova, E. A. 2011. Asset Liability management for individual households, British Actuarial Journal 16(2): 405-439. Cambridge Systems.

Denardo, E.V. 2003. Dynamic Programming: Models and Applications. Mineola, NY: Dover Publications. ISBN 978-0-486-42810-9.

De Vaney, S. A.; Lytton, R. H. 1995. Household Insolvency: A Review of Household Debt Repayment, Delinquency and Bankruptcy, Financial Services Review 4(2): 137-156.

Disney, R.; Gathergood J. 2013. Financial literacy and consumer credit portfolios, Journal of Banking \& Finance 37: 2246-2254.

Drijver, S. 2005. Asset Liability Management for Pension Funds using Multistage Mixed-integer Stochastic Programming. PhD thesis, University of Groningen. 
Duesenberry, J.S. 1949. Income, Saving and the Theory of Consumer Behavior. Harvard University Press, Cambridge, Mass.

Echenique, F.; Lee, S.; Shum, M. 2011. The Money Pump as a Measure of Revealed Preference Violations, Journal of Political Economy 119(6): 1201-1223. The University of Chicago Press. doi: $10.1086 / 665011$.

Elliott, R. 2013. The taste for green: the possibilities and dynamics of status differentiation through "green" consumption, Sci Verse ScienceDirect 41: 294-322.

Engel, E. 1857. Die Produktions und Consumtionsverhaltnisse des Konigreichs Sachsen. Reprinted with Engel (1895), Anlage I, 1-54.

Engel, J. F.; Kollat D. T.; Blackwell, R. D. 1968. Consumer Behavior. New York.

Euromonitor International [online]. 2013. Consumer Lifestyles in Greece [cited 16 May 2015]. Available from Internet: http://www.euromonitor.com/consumer-lifestyles-in-greece/report.

Euromonitor International [online]. 2015. 7 consumer types for successful targeted marketing [cited 22 October 2015]. Available from Internet: http://go.euromonitor.com/white-paper-7consumer-types-for-successful-targeted-marketing.html.

Eurostat [online]. 2016. Final consumption expenditure of households by consumption purpose [cited 15 January 2016]. Available from Internet: http://appsso.eurostat.ec.europa.eu/nui/ setupDownloads.do.

Eurostat [online]. 2016. GDP and main components [cited 15 January 2016]. Available from Internet: http://appsso.eurostat.ec.europa.eu/nui/show.do.

Faerber, E. 2005. The Personal Finance Calculator: How to Calculate the Most Important Financial Decisions in your Life. United States of America: McGraw Hill. 578 p.

Financial Services Authority (FSA) [online]. 2005. Measuring Financial Capability: An Exploratory Study [cited 12 February 2015]. Available from Internet: http://www.fsa.gov.uk/pubs/ consumerresearch/crpr37.pdf (25.07.2014)

Financial Times [online]. 2016. Definition of NPL ratio [cited 15 January 2016]. Available from Internet: http://lexicon.ft.com/Term?term=NPL-ratio.

Finke, M. S.; Smith, H. 2012. A financial sophistication proxy for the Survey of Consumer Finances, Applied Economics Letters 19(13). DOI: 0.1080/13504851.2011.619485.

Fisher, I. [online] 1930. The theory of interest, as determined by impatience to spend income and opportunity to invest it [cited 01 October 2015]. The online library of liberty. Available from Internet: http://files.libertyfund.org/files/1416/Fisher_0219.pdf.

Freud, S. 1904. Psychopathology of Everyday Life. Berlin, Germany.

Friedman, M. A. [online] 1957. Theory of the consumption function [cited 22 October 2015]. EconPapers. Available from Internet: http://econpapers.repec.org/bookchap/nbrnberbk/frie571.htm.

Fornero, E.; Monticone, C. 2011. Financial Literacy and Pension Plan Participation in Italy, Journal of Pension Economics and Finance 10(4):1-31. http://dx.doi.org/10.1017/S1474747211000473.

Foxall, G. 1990. Consumer Psychology in Behavioural Perspective. London: Routledge.

Geyer, A.; Hanke, M.; Weissensteiner, A. 2009. Life-cycle asset allocation and optimal consumption using stochastic linear programming, Journal of Computational Finance 12: 29-50.

Geyer, A.; Hanke, M.; Weissensteiner, A. 2010. No-arbitrage conditions, scenario trees, and multiasset financial optimization, European Journal of Operational Research 206: 609-613.

Gheorghiu, G. 2011. Rational Consumer Behavior and Its Importance for Real and Simulated Business Environment. Ovidius University Annals, Economic Science Series, 9(2): 
Gheorghiu G. 2011. Irational Consumer Behavior and Its Importance for Real and Simulated Business Environment. Ovidius University Annals, Economic Science Series 9(2):.

Giarda, E. 2013. Persistency of financial distress amongst Italian households: Evidence from dynamic models for binary panel data, Journal of Banking \& Finance 37: 3425-3434.

Ginevičius, R.; Podvezko, V. 2008. A feasibility study of multi-criteria methods' application to quantitative evaluation of social phenomena, Business: theory and practice 9(2): 81-87.

Ginevičius, R.; Podvezko, V. 2008. The problem of compatibility of various multiple criteria evaluation methods, Business: theory and practice 9(1): 73-80.

Ginevičius, R.; Podvezko, V. 2007. Some problems of evaluating multicriteria decision methods, International Journal of Management and Decision Making 8(5/6): 527-539.

Gitman, L. J.; Joehnk, M. D. 2005. Fundamentals of Investment. San Diego State University. 754 p.

Gitman, L. J.; Mazer, Ch. 2007. Basic Managerial Finance. New York: Harper \& Row Publisher. $453 \mathrm{p}$.

Gordon, M. G. 2008. The Life Cycle of Financial Planning. University of Wyoming Cooperative Extention Service. 420 p.

Grewal, R.; Cline, T. W.; Davies, A. 2003. Early-Entrant Advantage, Word-of-Mouth Communication, Brand Similarity, and the Consumer Decision-Making Process, Journal of Consumer Psychology 13(3): 187-197.

Griškevičius, V.; Kenrick, D. T.; Neuberg, S. L.; Schaller, M. 2010. Renovating the Pyramid of Needs: Contemporary Extensions Built upon Ancient Foundations, Perspectives of Psychological Science 5(3): 292-314. ISBN 9986057671.

Hall, A. 2006. Your Money on Your Life. London: Hodder \& Stoughton. 390 p.

Hall, R, E. 1978. Stochastic Implications of the Life Cycle Permanent Income Hypothesis: Theory and evidence, Journal of Political Economy 86(1): 971-987.

Haneveld, K.; Streutker, M. H.; van der Vlerk, M. H. 2010. An ALM model for pension funds using integrated chance constraints, Annals of Operations Research 177: 47-63.

Harrison, D. 2005. Personal Financial Planning: Theory and Practice. Edinburg: Financial Times, Prentice Hall. 555 p.

Helly, G. 2007. Financial literacy is eveyone's job, Credit World 84(6): 118-122. EBSCO Publishing.

Henry, A. [online] 2014. Five Best Personal Finance Tools [cited 26 March 2014]. Available from Internet: http://lifehacker.com/5828438/five-best-desktop-personal-finance-tools.

Herdrich, K. [online] 2008. Household Budget Management: Top Online Tools [cited 12 September 2015]. Available from Internet: http://www.womansday.com/life/workmoney/tips/a3892/household-budget-management-top-online-tools-78082/.

Hertwich, E. G.; Gibon, T.; Bouman, E.; Arvesen, A.; Suh, S.; Heath, G.; Bergesen, J.; Ramirez, A.; Vega, M.; Shi, L. 2015. Integrated life-cycle assessment of electricity-supply scenarios confirms global environmental benefit of low-carbon technologies. Proceedings of the National Academy of Sciences of the United States of America 112(20).

Hira, T. K. [online] 2009. Personal Finance: Past, Present and Future. In: Social Science Research Network [cited 12 February 2014]. Available from Internet: http://papers.ssrn.com/sol3/ papers.cfm?abstract_id $=1522299$.

Hite, N. G.; Slocombe, T. E.; Railsback, B.; Miller, D. 2011. Personal Finance Education in Recessionary Times, Journal of Education for Business 86(5): 253-257. doi:10.1080/08832323.2010.511304. 
Hocht, S.; Hwa, N. K.; Rosch C. G.; Zagst, R. 2008. Asset Liability Management in Financial Planning, The Journal of Wealth Management 11(2): 29-46.

Houthakker, H. S. 1953. Compensated Changes in Quantities and Qualities Consumed, Review of Economic Studies 19(3): 155-164.

Howard, J. A.; Sheth, J. N. 1969. The Theory of Buyer Behavior. New York: Wiley.

Hsu, C. C.; Sandford, B. A. 2007. The Delphi Technique. Making Sense of Consensus, Practical Assesment, Research \& Evaluation 12(10): 1-8.

Huffman, W. E. 2010. Household Production Theory and Models. In: Working Paper No. 10019, June 2010, Iowa State University, Department of Economics.

International Monetary Fund [online]. 2013. Technical note on the financial situation of Italian households and non-financial corporations and risks to the banking system [cited 10 October 2015]. Available from Internet: www.imf.org/external/pubs/ft/scr/2013/cr13348.pdf.

Investopedia [online]. 2015. Behavioral Finance: Background [cited 28 September 2015]. Available from Internet: http://www.investopedia.com/university/behavioral_finance/ behavioral2.asp.

Investopedia [online]. 2016. Definition of flow-of-funds [cited 18 January 2016]. Available from Internet: http://www.investopedia.com/terms/f/fof.asp.

Jappelli, T.; Pagano, M.; Di Maggio, M. 2008. Households' Indebtedness and Financial Fragility. 9th Jacques Polak Annual Research Conference, Washington, DC-November 13-14, 2008.

Jurevičienė, D.; Gausienè, E. 2010. Peculiarities of individuals financial behaviour, Verslas: teorija ir praktika [Business: Theory and Practice] 11: 54-60. ISSN 1310-3946.

Jurevičienė, D.; Klimavičienè, A. 2008. Life-cycle approach to personal financial management, Verslas: teorija ir praktika [Business: Theory and Practice] 9(1): 22-32. ISSN 1648-0627.

Jurevičienè, D.; Sukačevskytè, V. 2013. Factors of households'default, Journal Acta Oeconomica Universitatis Selye: Vedecký recenzovaný časopis 2(1): 131-143.

Jurevičienè, D.; Sukačevskytė, V. 2014. Factors affecting personal insolvency. KSI Transactions on Knowledge Society 7(3): 5-11.

Kahneman, D.; Tversky, A. 1979. Prospect theory: an analysis of decision under risk, Econometrica 47(2): 263-291.

Kamleitner, B.; Kirchler, E. 2007. Consumer credit use: a process model and literature review, Revue européenne de psychologie appliquée 57: 267-283.

Keese M. 2009. Triggers and determinants of severe household indebtedness in Germany, Ruhr economic papers 1:150.

Keynes, J. M. 1936. The General Theory of Employment, Interest and Money. London: Palgrave Macmillan.

Kim, H. J.; Lee, D.; Son, J. C.; Son, M. K. 2014. Household indebtedness in Korea: Its causes and sustainability, Japan and the World Economy 29: 59-76.

Konicz, A. K. 2012. A hybrid model for optimal decisions within personal finance and retirement. OR Seminar, Technical University of Denmark, Department of Technical Engineering.

Kirchler, E.; Hoelzl, E. \& Kamleitner, B. 2008. Spending and credit use in the private household, The Journal of Socio-Economics 37: 519-532.

Kuznets, S. 1951. Long-term changes in the national income of the United States of America since 1870. In: Income and wealth of the United States: trends and structure, International association for research in income and wealth, series II, Bowes \& Bowes, Cambridge.

Kyrk, H. 1923. A Theory of Consumption. Boston: Houghton Mifflin.

Kyrk, H. 1933. Economic Problems of the Family. New York: Harper. 
Lancaster, K. 1966. A New Approach to Consumer Theory, Journal of Political Economy 74(2): 132-157.

Landeta, J. 2006. Current validity of the Delphi method in social sciences, Technological Forecasting and Social Change 73(5): 467-482, doi.org/10.1016/j.techfore.2005.09.002.

Lazear, E. 2000. Economic Imperialism, Quarterly Journal of Economics 115(1): 99-146.

Lea, S. E. G.; Newson, L. 2006. Prospects for an evolutionary economic psychology: Buying and consumption as a test case. In: Paper for the 'The Evolution of Consumption' workshop, MaxPlanck-Institut für Ökonomik.

Levin, J.; Milgrom, P. [online]. 2004. Introduction to Choice Theory [cited 24 December 2014]. Available from Internet: http://web.stanford.edu/ jdlevin/Econ\%20202/Choice\%20Theory.pdf.

Lovell, M.; Lucas, R.; Mortensen, D.; Shiller, R.; Wallace, N. [online]. 2011. Rational Expectations: Retrospect and Prospect [cited 22 May 2014]. Available from Internet: http://public.econ.duke.edu/ kdh9/Source\%20Materials/Research/Rational\%20Expectations\%20P anel\%20_30\%20May\%202011_.pdf.

Lundberg, S.; Pollak, R. A. 2001. Efficiency in Marriage. In: The Meetings of the American Economic Association in New Orleans, p. 29.

Ludlow, J. 1975. Delphi inquiries and knowledge utilization. In H. A. Linstone, \& M. Turoff (Eds.). The Delphi method: Techniques and applications (pp. 102-123). Reading, MA: AddisonWesley Publishing Company.

Lusardi, A. 2006. Comment on: "A portfolio view of consumer credit", Journal of Monetary Economics 53: 85-88.

Lusardi, A.; Tufano, P. 2009. Debt Literacy, Financial Experience and Overindebtedness. NBER Working Paper, 14808.

Ludwig, B. 1997. Predicting the future: Have you considered using the Delphi methodology? Journal of Extension 35(5): 1-4.

Maldeikienė A. 2005. Išmokite skaičiuoti savo pinigus. Vilnius: Tyto Alba, 190 p.

Mankiw, N. G. 2011. Principles of Economics. $6^{\text {th }}$ Edition. Thomson Europe.

Mankiw, N. G. 2013. Macroeconomics (modified for EC 204 by Bob Murphy). Worth Publishers, $1-48$.

Maslow, A.H. [online]. 1943. A theory of human motivation, Psychological Review 50(4): 370-96 [cited 12 June 2014]. Available from Internet: http://psychclassics.yorku.ca/Maslow/ motivation.htm

Maslow, A. H. 1954. Motivation and Personality. New York, NY: Harper. p. 236. ISBN 0-06041987-3.

Mathur, V. K. 1991. How well do we know Pareto Optimality? The Journal of Economic Education 22(2): 172-178.

McLeod, S. [online]. 2007. Maslow's Hierarchy of Needs [cited 12 June 2014]. Available from Internet: http://www.simplypsychology.org/maslow.html.

Medova, E. A.; Murphy, J. K.; Owen, A. P.; Rehman, K. 2008. Individual asset liability management, Quantitative Finance 8(6): 547-560. doi: 10.1080/14697680802402691.

Meghir, C. 2004. A Retrospective on Friedman's Theory of Permanent Income. University College London and Institute for Fiscal Studies.

Members Equity Bank [online]. 2013. The financial psychology of Australian households: insights from national research [cited 01 October 2015]. Available from Internet: https://www.mebank.com.au/media/1233682/household_financial_comfort_report_dec_2012.pdf. 
Meng, X.; Hoang, N. T.; Siriwardana, M. 2013. The determinants of Australian household debt: A macro level study, Journal of Asian Economics 29: 80-90.

Meniago, C.; Petersen, J. M.; Petersena, M. A.; Mongale, I. P. 2013. What causes household debt to increase in South Africa? Economic Modelling 33: 482-492.

Ministry of Finance of the Rpublic of Lithuania [online]. 2011. The projection of main macroeconomic indexes in Lithuania [cited 15 December 2011]. Available from Internet: http://www.finmin.lt/web/finmin/aktualus_duomenys/makroekonomika.

Modigliani, F.; Brumberg, R. 1954. Utility analysis and the consumption function: an interpretation of cross-section data. In: Kurihara, K.K (ed.): Post-Keynesian Economics.

Muth, J. 1961. Rational Expectations and the Theory of Price Movements, Econometrica 29(3): 315-335.

Nicholson, W. 2005. Microeconomic Theory: Basic Principles and Extensions. Mason, OH: Thomson/Southwestern. ISBN 0-324-27086-0.

Numbeo [online]. 2015. Cost of Living Index for Country 2015 [cited 10 April 2015]. Available from Internet: http://www.numbeo.com/cost-of-living/rankings_by_country.jsp.

Ody E. 2010. Make Money Work for You, Kiplinger's Personal Finance 64(8): 201-209. MERLOT Publishing.

Ogawa, K.; Wan, J. 2007. Household debt and consumption: A quantitative analysis based on household micro data for Japan, Journal of Housing Economics 16: 127-142.

Oracle [online]. 2012. The connected consumer: evolving behavior patterns. A consumer research study [cited 01 October 2015]. Available from Internet: www.oracle.com/us/.../retail/researchconnected-consumer-1736894.pdf.

Pahl, J. 2008. Family finances, individualisation, spending patterns and access to credit, The Journal of Socio-Economics 37: 577-591.

Palda, F. 2013. The Apprentice Economist: Seven Steps to Mastery. Cooper-Wolfling. 293 p.

Parker, J. 2010. 16 Theories of Consumption and Saving. Economics 314 Courcebook. 16-24.

Pedersen, A. M. B.; Rasmussen, K. M.; Vladimirou, H.; Clausen, J. 2010. Integrated mortgage loan and pension planning. Working paper.

Pedersen, A. M. B.; Weissensteiner, A.; Poulsen, R. 2013. Financial planning for young households, Annals of Operations Research 205(1): 55-76.

Persky, J. 1995. The Ethology of Homo Economicus. The Journal of Economic Perspectives 9(2): 221-231.

Phung, A. [online] 2011. Behavioral Finance [cited 23 October 2013]. Available from Internet: http://i.investopedia.com/inv/pdf/tutorials/BehavioralFinance.pdf.

Pollak, R. A.; Wachter, M. L. 1975. The Relevance of the Household Production Function And Its Implications for the Allocation of Time, The Journal of Political Economy 83(2): 255-277.

Pollak, R. A. 1985. A Transaction Cost Approach to Families and Households, Journal of Economic Literature 23(2): 581-608.

Pollak, R. A. 2002. Gary Becker's Contributions to Family and Household Economics, Review of Economics of the Household 1(1): 111-141.

Pratz, A.; Chikova, D.; Freddi, R.; Castro, P.; Hewlett, P. [online] (2015). The 2015 Retail Banking Radar [cited 11 November 2015]. Available from Internet: https://www.atkearney. com/documents/10192/5903614/Time+to+Reinvent+Your+Banking+Model.pdf/ec08fb0d-44e8$4 c 83-9 b 58-37 d 731515 b f 5$. 
Princeton Survey Research Associates International [online]. 2015. Only a minority of americans keep close track of their spending [cited 10 October 2015]. Available from Internet: http://www.psra.com/news.aspx?titleId=905\&archive=true.

Prinsloo, J. W. 2002. Household debt, wealth and saving. Quarterly Bulletin. December 2002, SA RESERVE BANK.

Rae J. [online] 1834. The sociological theory of capital. London: MacMillan [cited 01 October 2015]. Available from Internet: https://archive.org/stream/sociologicaltheo00raejuoft/ sociologicaltheo00raejuoft_djvu.txt.

Rakauskienė O. G.; Bikas E. 2007. Saving of Lithuania's people: the models of men and women saving behaviour, Ekonomika [Economics] 79: 125-140. ISBN 9788370119805.

Ramanauskas, T.; Jakaitienè, A. 2007. Modelling the consumption of households, Monetary Studies 1: 25-44.

Ramsey, F. P. 1928. A Mathematical Theory of Saving, Economic Journal 38(152): 543-559.

Reid, M. 1934. The Economics of Household Production. New York: Wiley, p. 426.

Reifner, U.; Kiesilainen, J.; Huls, N.; Springeneer, H. [online]. 2003. Consumer Overindebtedness and Consumer Law in the European Union. Institute for financial services, Erasmus University Rotterdam/School of Law, University of Helsinki to the Commission of the European Communities. 252 p. [cited 12 March 2015]. Available from Internet: http://www.ecri.eu/ new/system/files/26+consumer_overindebtedness_consumer_law_eu.pdf.

Ribeaux, P.; Poppleton, S. E. 1978. Psychology and work. London: Macmillan Education.

Ricciardi, V.; Simon, H. K. [online]. 2000. What is Behavioral Finance? Business, Education and Technology Journal [cited 12 March 2014]. Available from Internet: http://www.researchgate.net/profile/Victor_Ricciardi/publication/234163799_What_is_Behavioral _Finance/links/02bfe50f9696f22858000000.pdf.

Richarme, M. 2005. Consumer Decision Making-Models, Strategies and Theories, Decision Analyst 1:1-3.

Rose, J. [online] 2016. Ready to start investing? The best online brokers for beginners [cited 26 January 2016]. Available from Internet: http://www.goodfinancialcents.com/best-online-stockbrokers-for-beginners-small-investors/.

Rose, J. [online] 2012. The 11 best Personal Finance Software to Get Your Money Swag on [cited 27 April 2015]. Available from Internet: http://www.goodfinancialcents.com/best-personalfinance-software-free-to-download/.

Rudzkienė, V. 2014. Research methods. Lecture material. Mykolas Romeris University.

Runkle, D. E. 1991. Liquidity constraints and the permanent-income hypothesis: Evidence from panel data, Journal of Monetary Economics 27(1): 73-98.

Rutkauskas A. V. 1999. Personal finance as a subsystem of country's financial system, Inžinerine ekonomika [Engineering Econimics] 4(15): 50-55.

Rutkauskas, A., V.; Miečinskienè, A.; Stasytytè, V. 2008. Investment decisions modelling along sustainable development concept on financial markets, Technological and Economic Development of Economy 14(3): 417-427.

Rutkauskas A. V., Stasytytè V. 2011. Optimal portfolio search using efficient surface and threedimensional utility function, Technological and Economic Development of Economy 17(2): 291312. ISSN 2029-4913.

Rutkauskas A. V., Žilinskij G. 2010. Financial leverage usage for active management of the investment portfolio, Verslas: teorija ir praktika [Business: Theory and Practise] 11(3): 194-203. ISSN 1648-0627. 
Sage [online] 2016. Prospero Asset Management Software [cited 12 November 2015]. Available from Internet: http://www.sage.ch/products/prospero-asset-management/?gclid=CjwKEAiAmY3BRDh7pjvg46p1iYSJADQ78gNacGjUrolaPzJSEYEdWo1hkNPGq5KFG5ZBf4gYtEwJRoCGY -W_wcB.

Salvatore, D. 2008. Microeconomics: Theory and Applications. Oxford University Press. ISBN: 9780195336108.

Samuelson, P. A. 1938. A Note on the Pure Theory of Consumers' Behaviour, Economica 5(7): 61-71. JSTOR 2548836.

Samuelson, P. A. 2007. Keynote address. In: The Future of Life-Cycle Saving and Investing.

Samuelson P. 1970. What makes for a beautiful problem in science? Journal of Political Economy 78(6): 1372-1377.

Sargent, T. J. Rational Expectations [online] 2008. In: Library Economics Liberty [cited 14 June 2014]. Available from Internet: http://www.econlib.org/library/Enc/RationalExpectations.html.

Schiffman, L. G.; Kanuk, L. L. 2007. Consumer behavior. 9th ed. New Jersey: Prentice Hall.

SEB bank [online]. 2011. Basic macroeconomic indexes of Lithuania and its analysis [cited 10 December 2011]. Available from Internet: 〈http://www.seb.lt/pow/wcp/seblt.asp〉.

SEB bank [online]. 2015. Baltic Household Outlook [cited 22 January 2016]. Available from Internet: https://www.seb.lt/..//baltic_household_outlook/bho_20151104.pdf ·

Securities Commision of the Republic of Lithuania [online]. 2010. Lithuanians lack of financial knowledge [cited 15 December 2011]. Available from Internet: http://www.vpk.lt/lt/ vpkpranesimai/investuotoju-svietimas/14113/

Sekita, S. 2011. Financial Literacy and Retirement Planning in Japan, Journal of Pension Economics and Finance 10(4): 637-656. http://dx.doi.org/10.1017/S14 74747211000527.

Sewell, M. [online]. 2007. Behavioural Finance. University of Cambridge [cited 18 February 2014]. Available from Internet: http://www.behaviouralfinance.net/behavioural-finance.pdf.

Sharf, S. [online]. 2016. 12 Free Apps to Track Your Spending and how to pick the Best One for You [cited 23 July 2015]. Available from Internet: http://www.forbes.com/sites/samanthasharf/ 2016/03/02/12-free-apps-to-track-your-spending-and-how-to-pick-the-best-one-foryou/\#282c8ff52b69.

Silberberg, S. 2001. The Structure of Economics, A Mathematical Analysis. McGraw-Hill.

Simon, H. A. 1976. Administrative Behavior: a Study of Decision-Making Processes in Administrative Organization (3rd ed.). New York: Free Press. ISBN 0029289718.

Simon, H. A. 1991. Models of My Life. New York: Basic Books. ISBN 0465046401.

Simon, H. 1997. Administrative behavior: a study of decision-making processes in administrative organizations. 4th ed. ed. New York: The Free Press.

Simple Economist [online] 2015. Household Production Theory [cited 26 October 2015]. Available from Internet: http://simpleeconomist.com/household-production-theory/.

Smith, A. (1776) (1981). An Enquiry into the Nature and Causes of the Wealth of Nations. Indianapolis: Liberty Classics [The classical work in political economy].834 p.

Smith, N. R. 1964. Consumer behavior patterns, Journal of Extension 2(1):45-53.

Sniedovich, M. 2010. Dynamic Programming: Foundations and Principles. Taylor \& Francis. ISBN 978-0-8247-4099-3.

Solomon, M.; Bamossy, G.; Askegaard, S.; Hogg, M. K. 2006. Consumer Behaviour: A European Perspective. 3rd ed. Harlow: Prentice Hall. ISBN-13: 978-0273717263. 
Stankevičienė, J,; Rutkauskas, A. V.; Stasytytė, V. 2009. Profit, riskness and reliability - three dimensional base for investment decisions management. Modeling and Analysis of Safety and Risk in Complex Systems. Saint Petersburg: SUAI, 2009. ISBN 978508804609, p. 105-110.

Statistics Lithuania [online]. 2008. Households budget survey [cited 15 December 2011]. Available from Internet: http://www.stat.gov.lt/lt/pages/view/?id=1335.

Statistics Lithuania [online]. 2009. Residents and Social Statistics [cited 25 March 2009]. Available from Internet: http://db1.stat.gov.lt/statbank/SelectTable/Omrade0.asp?SubjectCode $=\mathrm{S} 3 \&$ ShowNews $=$ OFF \&PLanguage $=0$.

Stewart, J. 1994. The psychology of decision making. In: D. Jennings and S. Wattam, eds. Decision Making: an Integrated Approach. London: Pitman.

Sutherland, S. [online]. 2012. Behavioural finance - An opportunity for smart investors [cited 12 September 2014]. Available from Internet: http://www.isaco.co.uk/blog/bid/147160/Behaviouralfinance-An-opportunity-for-smart-investors.

Syll, L. P. [online]. 2011. Robert Lucas, Rational Expectations and the Understanding of Business Cycles. In: Economics, Theory of Science and Methodology [cited 20 April 2014]. Available from Internet: https://larspsyll.wordpress.com/2011/05/16/robert-lucas-rational-expectations-and-theunderstanding-of-business-cycles/.

Swedbank Personal Finance Institute [online]. 2010. Investigation about personal finance [cited 20 December 2011]. Available from Internet: https://www.manofinansai.lt/lt/articles/view/13

Tapsin, G.; Hepsag, A. 2014. An analysis of household consumption expenditures in EA-18, European Scientific Journal 10(16): 1-12. ISSN: 1857 - 7881 (Print) e - ISSN 1857- 7431.

Titko, J.; Lace, N.; Polajeva, T. 2015. Financial Issues Perceived by Youth: Preliminary Survey for Financial Literacy Evaluation in the Baltics, Quarterly Journal OeconomiA Copernicana 6(1): 75-98. ISSN 2083-1277, e-ISSN 2353-1827. DOI: http://dx.doi.org/10. 12775/OeC.2015.004.

The Bank of Lithuania [online]. 2016. Review of banking performance in 2015 [cited 22 November 2015]. Available from Internet: http://www.lb.lt/banku_apzvalga_2015_m_iv_ketvirtis.

The Bank of Lithuania [online]. 2015. An overview of household survey on financial behaviour [cited 22 November 2015]. Available from Internet: http://www.lb.lt/namu_ukiu_finansines_ elgsenos_apklausos_apzvalga_2015_nr_1_2.

The Bank of Lithuania [online] 2015. The Review of Commercial Banks Performance in Lithuania [cited 10 January 2016]. Available from Internet: https://www.lb.lt/n25606/ 2015_06_12_banku_veiklos_apzvalga_2015q1.pdf

The Bank of Lithuania [online]. 2015. Methodological Notes [cited 12 October 2015]. Available from Internet: https://www.lb.lt/methodological_notes_2.

The Bank of Lithuania [online]. 2015. Profit and loss report of commercial banks and foreign bank branches in Lithuania [cited 22 October 2015]. Available from Internet: https://www. lb.lt/stat_pub/Graph/GraphForm.aspx?group=8014\&form_id=BX2_B.S1\&lang=1t\&dtstart=2013\% $2 \mathrm{c} 03 \% 2 \mathrm{c} 31 \& \mathrm{dtend}=2014 \% 2 \mathrm{c} 06 \% 2 \mathrm{c} 30$.

The Bank of Lithuania [online]. 2014. Banks activities overview [cited 22 October 2015]. Available from Internet: https://www.lb.lt/banku_apzvalga_2014_m.

The Bank of Lithuania. 2014 [online]. The review of households survey on financial behavior [cited 22 October 2015]. Available from Internet: https://www.lb.lt/namu_ukiu_finansines_elgsenos_ apklausos_apzvalga_2014_nr_.

The Bank of Lithuania [online]. 2012. The concept of financial education [cited 14 March 2015]. Available from Internet: https://www.lb.lt/n21049/finansinio_svietimo_koncepcija.pdf.

The European Central Bank [online]. 2006. Monetary financial institutions [cited 12 May 2015]. Available from Internet: https://www.ecb.europa.eu/stats/money/mfi/general/html/index.en.html. 
The Human Condition Organisation [online]. 2013. Utility and Utilitarianism [cited 18 December 2014]. Available from Internet: http://humancond.org/analysis/economics/value/utility_and_ utilitarianism.

The Official Website of the Nobel Prize [online].. 2015. Angus Deaton - facts [cited 22 October 2015]. Available from Internet: http://www.nobelprize.org/nobel_prizes/economicsciences/laureates/2015/deaton-facts.html.

The World Bank [online]. 2016. Household final consumption expenditure [cited 16 January 2016]. Available from Internet: http://data.worldbank.org/indicator/NE.CON.PETC.ZS/countries? display $=$ map.

The World Bank [online]. 2012. Household final consumption expenditure (current US\$) [cited 17 March 2015]. Available from Internet: http://data.worldbank.org/indicator/NE.CON.PRVT.CD

The Wolrd Bank. 2016. World development indicators: level of non-performing loans in different countries [cited 25 January 2016]. Available from Internet: http://databank.worldbank.org/data/ reports. asp $x$ ?source $=2 \&$ type $=$ metadata $\&$ series $=F B$.AST.NPER.ZS\#.

The World Post [online]. 2015. 18 Countries That Love To Eat, Drink \& Smoke More Than The U.S [cited 23 October 2015]. Available from Internet: http://www.huffingtonpost.com/2013/09/06/ countries-that-love-to-eat-drink-smoke_n_3880324.html.

Tyson E. 2010. Personal Finance for Everybody. Canada: Wiley Publishing. 320 p.

Underwood A. 2010. Are Your Bills Making You Fat, Prevention 62(10): 45-49. MERLOT Publishing.

Vahidov, R.; He, X. 2009. Situated DSS for personal finance management: Design and evaluation Information \& Management 46(8): 453-462.

Vainienè, R. [online]. 2016. "Household" definition [cited 12 May 2015]. Available from Internet: http://zodynas.vz.lt/Namu-ukis.

Varian, H. R. 2006. Intermediate Microeconomics: A Modern Approach. International ed., WW Norton \& Company. ISBN 81-7671-058-X.

Vitunskienè, V. 1997. Household economics. Vilnius. 204 p.

Von Neumann, J.; Morgenstern, O. 1947. The Theory of Games and Economic Behavior. Second edition, Princeton: Princeton University Press.

Waksberg J. 2011. Sampling Methods for Random Digit Dialing, Journal of the American Statistical Association 73(361): 40-46.

Walters, A.; Smith, A. 2010. Bankruptcy Tourism' under the EC Regulation on Insolvency Proceedings: A View from England and Wales, International Insolvency Review 19(3): 181-208.

Wang, L.; Lu, W.; Malhotra, N. K. 2011. Demographic, attitude, personality and credit card features correlated with credit card debt: A view from China, Journal of Economic Psychology 32: 179-193.

Wealth Management Institute [online]. 2015. Why financial planning works? [cited 01 October 2015]. Available from Internet: http://www.wealthmanagementpro.com/new/wealthmanage mentinstitute/content.asp? contentid $=2017891741$.

Weaver, W. T. 1971. The Delphi forecasting method, Phi Delta Kappan 52(5): 267-273.

Winger B.; Frasca R. R. 2006. Personal Finance. University of Dayton: Pearson. 421 p.

Worthington, A. C. 2006. Debt as a source of financial stress in Australian households, International Journal of Consumer Studies 30(1): 2-15.

Wyburn, M. 2014. Debt Agreements for Consumers under Bankruptcy Law in Australia and Developing International Principles and Standards for Personal Insolvency, International Insolvency Review 23: 101-121. 
Wyman, O. 2013. European Retail Banking. An Opportunity for a Renaissance. Marsh \& McLennan Companies. 22 p.

Ziemba, W. T.; Mulvey, J. M. 1998. Worldwide Asset and Liability Modelling. Cambridge University Press. 680 p.

Zimmerman, C. C. 1932. Ernst Engel's Law of Expenditures for Food, The Quarterly Journal of Economics 47(1): 78-101.

Zinkhman, G. M. 1992. Human nature and models of consumer decision making, Journal of Advertising 21(4):2-3.

Yacht C., Siegel R. 2010. Personal Finance. University of Yale: McBook. 300 p. 


\section{List of Scientific Publications by the Author on the Topic of the Dissertation}

Jurevičienė, D.; Taujanskaite, K.; Sukačevskyte, V. 2016. Indirect Factors Affecting Personal Solvency: Empirical Analysis of Lithuanian Credit Market, European Scientific Journal. Macedonia: European Scientific Institute 12(1): 157-175.

Taujanskaitè, K.; Milčius, E.; Rutkauskas, A. V. 2015. Integrated Cross Disciplinary Approach to Household Expenditure Management, Engineering Economics. Kaunas: Technika 26(5): 489-499.

Taujanskaitè, K.; Milčius, E. 2015. Management of Household Expenditure by Using Value Decomposition Technique. 1st International Conference on Business Management. Universitat Politècnica de València. Spain, Valencia.

Taujanskaite, K.; Milčius, E. 2014. Development and Sustainability Risks of Lithuanian Consumer Credit Market. Procedia-Social and Behavioral Sciences. Amsterdam: Elsevier 110(2014):1185-1196. ISSN 1877-0428.

Taujanskaitè, K.; Milčius, E. 2012. Impact of Financial Crisis on Lithuanian Households' Ability to manage Budgets. The 7th international scientific conference "Business and Management 2012": selected papers. Vilnius: Technika 233-240. ISSN 2029-4441. ISBN 9786094571169.

Taujanskaitè, K. 2011. Namų ūkių finansinès elgsenos pokyčiai ekonominès krizès laikotarpiu Lietuvoje. 1st International Scientific Conference: to Consolidate Researches of Academicians and Practitioners. Vilnius: MRU 215-223. 
Taujanskaitė, K.; Jurevičienė, D. 2010. Asmeninių finansų valdymo ypatumai ekonominio nestabilumo sąlygomis. Mokslas-Lietuvos ateitis: Verslas XXI amžiuje. Vilnius: Technika, 2(2): 104-111. ISSN 2029-2341. 


\section{Summary in Lithuanian}

\section{IVadas}

\section{Problemos formulavimas}

Namų ūkių (NŪ) vartojimui skirtų finansinių srautų apimtys skaičiuojant išlaidų metodu Lietuvoje sudaro apie $2 / 3$ bendrojo šalies vidaus produkto (BVP). Vien dèl to jų reikšmė yra ypatinga tiek visos šalies ekonominei sistemai, tiek atskirai paimtam kiekvienam jos subjektui nepriklausomai nuo veiklos pobūdžio ar segmento, kuriame jis veikia: gamybos, paslaugų, ịskaitant ir finansines.

Ekonominès sistemos funkcionavimui daro itaką ir šiu srautų apimtys, ir jų valdymo pobūdis bei efektyvumas. Jei prekių ir paslaugų rinkoms ir jų funkcionavimui didžiausią ịtaką turi apimtys, tai namų ūkiams, jų biudžetams, taip pat su namų ūkiais bendradarbiaujančioms finansinėms institucijoms ypač svarbūs yra jų valdymo kokybę lemiantys parametrai. Nuo finansiniu srautų valdymo efektyvumo, visų pirma, priklauso pačių namų ūkių gerovė, jų biudžetų būklè. Tai, kad labai reikšminga Lietuvos namų ūkių dalis (ivairiais duomenimis, nuo 30 iki $40 \%$ ) nesuvaldo biudžetų ir jų išlaidos viršija gaunamas pajamas, liudija apie rimtas problemas šioje srityje. Su tuo neabejotinai susijęs ir namų ūkių gebejjimas vykdyti prisiimtus finansinius ịsipareigojimus. Privatiems klientams išduotu neveiksnių paskolų lygis (NPL) Lietuvos komerciniuose bankuose $2015 \mathrm{~m}$. siekè 5,5\% (Lietuvos bankas, 2016). Nors ir sumažèjęs, palyginti su 2008-2010 m. krizès laikotarpiu (2009-8\%, 2010 m. - 20\%), jis vis dar išlieka kelis kartus aukštesnis nei iki krizès, kai jis siekè tik 1-2\%. Tokia paskolų portfelio būklè lèmė patirtus didelius komercinių bankų nuostolius, kurių jiems nepavyko kompensuoti net iki 2014 m. pabaigos. Taigi namų ūkių finansinių srautų valdymo efektyvumas yra ne mažiau 
svarbus, kaip ir jų apimtys. Šios problemos aktualios ne tik Lietuvos, bet ir kitų šalių ekonomikoms ir bankų sistemoms. Pavyzdžiui, $2015 \mathrm{~m}$. neveiksnių paskolų portfelio dalis Italijoje sudare $17,3 \%$, Airijoje $18,8 \%$, Graikijoje $34,4 \%$, o Kipre net $44,8 \%$ (Pasaulio bankas, 2016). Italijos neveiksnių paskolų portfelio vertè 2015 m. siekè 200 mlrd. eurų, o Europos Sajungos neveiksnių paskolų portfelis vertinamas 1 trilijonu eurų, arba apie $7 \%$ bendro šiu šalių BVP. Tai labai rimta, neatidèliotinų sprendimų reikalaujanti problema.

Lietuvos banko duomenimis (Lietuvos bankas, 2015), net 88 \% Lietuvos gyventojų nurodo, kad finansinius sprendimus priima remdamiesi savo asmenine patirtimi arba nuomone, kuriai turi jitakos pažįstamu asmenų patarimai, informacija spaudoje, televizijoje ir internete. Šiuo pagrindu suformuoti finansinių sprendimų motyvai nekelia pasitikejimo, todèl nestebina ir tai, kad tokia didelè namų ūkių dalis susiduria su finansų / biudžetų valdymo problemomis. Valdymo kokybė neabejotinai pagerètų, jei sprendimai būtų priimami remiantis objektyviais, kiekybiškai apibrěžtais kriterijais ir taikant specialias priemones, leidžiančias eliminuoti ar bent apriboti tokio pobūdžio motyvų ịtaką, pavyzdžiui, formalizuojant finansinių sprendimų prièmimo procedūras.

Daugelis tyrimų, tarp jų ir atliktų Lietuvos banko bei komercinių bankų pastangomis, atskleidžia, jog Lietuvos namų ūkiai stokoja ekonominių žinių ir finansų valdymo igūdžių. Ir namu ūkiai, ir su jais bendradarbiaujantys komerciniai bankai, susiduria su nepageidaujamomis, bendras šaknis turinčių reiškinių pasekmèmis, todèl jie galètų būti natūralūs partneriai kartu kovojant su šiais reiškiniais ir ju priežastimis. Tikètina, kad toks bendradarbiavimas galètų būti abipusiškai naudingas. Tokia partnerystė galètų sukurti tam tikrą sistemą, kurios subjektais būtu finansinių žinių stokojantys, bet komerciniams bankams kaip klientai svarbūs namų ūkiai, ir žinių, specialistų bei techninių priemonių arsenalą turintys komerciniai bankai.

Priežasčių, sukeliančių ịvardytas pasekmes identifikavimas ir adekvatus jų valdymas labai padètų efektyviau valdyti namų ūkiu biudžetus, pagerintų komercinių bankų privatiems asmenims išduotų paskolų portfelio kokybę, kartu prisidètų prie šalies makroekonominių rodiklių gerinimo. Būtent šie motyvai lèmè tyrimų krypties pasirinkimą.

\section{Darbo aktualumas}

İvairūs su vartojimu susijusių finansinių srautų valdymo aspektai ekonomikos moksle plačiai analizuojami nuo 18 a. pradžios, vis dèlto išlieka nemažai neatsakytų klausimų, ypač susijusių su vartojimo išlaidų valdymu dinamiškoje ir nuolat kintančioje šiuolaikineje ekonomineje aplinkoje. Didžioji dalis šių mokslinių tyrimų buvo vykdomi nagrinejjamus procesus vertinant iš makroekonomikos pozicijų (Smith 1776; Keynes 1936; Kuznets 1951 ir kt.).Vertinant šiuo požiūriu, vienas iš svarbiausių ekonomikos būklę lemiančių veiksnių yra vartojimo aktyvumas - kuo jis didesnis, tuo palankesnès sąlygos jai gerèti, taigi visus ar beveik visus finansinius išteklius einamajam vartojimui išleidžiantis individas ar namų ūkis šia prasme laikomi palankiais. Paradoksalu, tačiau ị idealių vartotojų kategoriją, tokiu atveju, turètų patekti ir žalingu ịpročių turintys, nuo svaigalų, azartinių lošimų ar pirkimo manijos priklausomi vartotojai, todėl šio požiūrio taikymas neabejotinai turi tam tikras ribas. Moksliniu tyrimu iš mikroekonomikos, konkrečiai iš namų ūkių pozicijų, grindžiamų būtent jų gaunamos naudos vertinimu, apimtys lyginant su makroekonominiu požiūriu yra daug mažesnès, didžioji jų dalis buvo atlikta iki XX a. vidurio (Bernoulli 1738; Kyrk 1923; Becker 1960 ir kt.) ir neįvertina naujausių tendencijų vartojimo rinkose. Iracionali vartojimo ir finansinè 
elgsena, kuriai makroekonominis požiūris iš esmès yra indiferentiškas, neigiamai veikia tiek pačius namų ūkius, su jais susijusias finansines institucijas (komercinius bankus, kredito įstaigas), tiek bendraja visuomenès socialine gerove besirūpinanti viešaji sektorių. Dėl šios priežasties mikroekonominio požiūrio plètra tampa labai aktuali, ypač žinant, kokị poveikị vartojimui turi naujausių pasiekimų ekonomikos, psichologijos, moderniųų komunikacinių technologijų ir kitų mokslo sričių pagrindu ištobulinti pardavimo metodai.

Neoklasikinès ekonominès teorijos, traktuojančios vartotoją kaip racionalų (Zinkhman 1992; Ansari 2000), aiškias preferencijas turintị ir biužeto galimybių ribose veikiantị individą, apibūdinamą bendriniu ,homo economicus“ vardu, negali paaiškinti, kodèl tokia didelè namų ūkių dalis susiduria su biudžeto deficito problemomis, kurias sunku pagrịsti nepakankamu pajamų lygiu. Moderniosios vartotojo elgsenos teorijos pabrèžia prielaidų dèl vartotojo racionalumo sąlyginumą ir atkreipia dèmesị i racionalumo stokojančių psichologinio pobūdžio motyvų įtaką, tačiau nesiūlo būdų, kaip jų poveikị būtų galima racionaliai valdyti. Moksliniai šaltiniai nepateikia atsakymų $\mathrm{i}$ tokius aktualius šiam tyrimui klausimus, kaip pajamų lygio ir vartojimo elgsenos įtaka namų ūkių biudžetų subalansavimui ir komercinių bankų privačių klientų mokumui; kaip turètų būti priimami namų ūkių finansiniai sprendimai elementariųjų pirkinių lygiu, kokią ịtaką jiems turi subjektyvūs psichologinio pobūdžio motyvai; kaip ir kokiais principais formuoti namų ūkių vartojimo suminių finansinių srautų valdymą šalies mastu, atsižvelgiant ị atskirų namų ūkių ir komercinių bankų interesus bei sieki gauti maksimalią abipusę naudą iš jų tarpusavio sąveikos.

\section{Tyrimy objektas}

Darbo tyrimų objektas - asmeniniam vartojimui skirtų finansinių srautų valdymo probleminiai aspektai namų ūkių ir komercinių bankų požiūriu.

\section{Darbo tikslas}

Šio darbo tikslas - modifikuoto namų ūkių ir komercinių bankų bendradarbiavimo pagrindu suformuoti bei teoriškai pagrịsti namų ūkių vartojimo piniginių srautų formalizuoto valdymo sistemą, aprépiančią tiek elementariujų pirkinių, tiek visuminio vartojimo šalies mastu lygius.

\section{Darbo uždaviniai}

Darbo tikslo siekiama sprendžiant šiuos 5 uždavinius:

1. Ištirti ir tarpusavyje palyginti namų ūkių vartojimo piniginius srautus prekių-paslaugų ir mažmeninès bankininkystès rinkose, identifikuoti jų valdymo problemas namų ūkių ir komercinių bankų požiūriu.

2. Išanalizuoti namų ūkių vartojimo piniginių srautų valdymo teorines koncepcijas, principus, praktiniam naudojimui skirtas priemones, nustatyti jų trūkumus bei numatyti tobulinimo galimybes.

3. Pasiūlyti kiekybiniais kriterijais pagrịstą formalizuoto valdymo metodiką, skirtą valdyti vartojimo išlaidas elementariųų pirkinių lygiu. 
4. Ištirti ir kiekybiškai ịvertinti individų vartojimo ir finansinès elgsenos įtaką banko klientų mokumui ir komercinių bankų veiklos rezultatams.

5. Sukurti namų ūkius ir komercinius bankus jungiančią vartojimo finansinių srautų valdymo sistemą, pagrịstą formalizuotomis sprendimų prièmimo procedūromis, ir pasiūlyti šios sistemos atsiperkamumo ìvertinimo metodą.

\section{Tyrimu metodika}

Mokslinių šaltinių tyrimas atliktas naudojant lyginamosios, loginès analizès, apibendrinimo, konkretizavimo, sisteminès ir kritinès analizės metodus.

Informaciniai šaltiniai apie metodus, modelius ir praktines priemones valdyti namų ūkių finansiniams ištekliams, tyrinèti naudojant lyginamosios, loginès ir kritinès analizès metodus.

Piniginiu srautų prekių-paslaugų ir mažmeninès bankininkystės rinkose tyrimui taikyti statistinių duomenų apdorojimo ir loginès analizès metodai.

Prekiu ir paslaugų vertès dekompozicijos tyrimai atlikti taikant ekonomikos ir psichologijos (Maslow poreikių hierarchija) teorijų sintezę, vektorių ir matricų algebrą.

Namų ūkių finansine elgsena ir finansinis išprusimas tirtas atliekant sociologinius tyrimus ir naudojant anketinès apklausos bei lyginamosios analizès metodus.

Neveiksnių paskolų priežasčių tyrimai atlikti ekspertinio vertinimo (Delphi) metodu.

Vartojimo finansinių srautų valdymo sistema sukurta remiantis statistinių duomenų dinamikos mažmeninèje bankininkysteje analize, o jos efektyvumo tyrimai atlikti naudojant matematinès analizès ir diferencinio skaičiavimo metodus.

\section{Darbo mokslinis naujumas}

Rengiant disertaciją buvo gauti šie ekonomikos mokslui nauji rezultatai:

1. Kontekstas, kai vartojimo finansiniai srautai, namų ūkių biudžetų ir paskolų būklè tiriama namų ūkių ir komercinių bankų bendrų interesų požiūriu, literatūroje iki šiol nebuvo nušviestas.

2. Maslow poreikių ir ekonomikos teorijų sintezès pagrindu pasiūlyti prekiu ir paslaugu vertes dekompozicijos principai, leidžiantys kiekvieno pirkinio atveju kiekybiškai ịvertinti jo vertès komponentes ir tinkamumą konkretaus vartotojo poreikiams tenkinti.

3. Pasiūlyta formalizuoto namų ūkių vartojimo išlaidų valdymo metodika, leidžianti kiekvieno elementaraus pirkinio finansavimą derinti su disponuojamais finansiniais ištekliais, eliminuojant subjektyvių psichologinio pobūdžio motyvų įtaką.

4. Nustatyti ir suklasifikuoti tiesioginiai bei netiesioginiai veiksniai, lemiantys paskolų gavejjų mokumą, kiekybiškai ịvertintas jų poveikis neveiksnių paskolų komerciniuose bankuose lygiui.

5. Pasiūlyta namų ūkius ir komercinius bankus jungianti, formalizuotomis sprendimų prièmimo procedūromis grịsta, vartojimo piniginių srautų valdymo sistema bei investicijų $\mathfrak{i}$ šios sistemos sukūrimą atsiperkamumo vertinimo metodas. 


\section{Darbo rezultatų praktinè reikšmè}

Darbo rezultatai, turintys praktinę reikšmę:

1. Formalizuoto vartojimo išlaidų valdymo principai gali būti naudojami kuriant taikomąsias programas namų ūkių biudžeto planavimui ir finansinių ištekliu paskirstymui elementariujų pirkinių lygiu, išvengiant subjektyvių, psichologinio pobūdžio veiksnių ịtakos šiems procesams.

2. Darbe sukurtos taikomosios programos gali būti naudojamos namų ūkiuose, siekiant efektyviau valdyti jų finansinius išteklius ir geriau kontroliuoti biudžetus.

3. Poveikio suminiams vartojimo piniginiams srautams formavimo sistema gali būti naudojama didinti namų ūkių finansinès, ypač vartojimo elgsenos efektyvumą, tuo pačiu tikintis neveiksnių paskolų lygio mažèjimo ir mažmeninių bankų apyvartos augimo.

\section{Ginamieji teiginiai}

1. Su namų ūkių vartojimu susiję finansiniai srautai pasiskirsto tarp vartojimo ir finansų rinkų, tačiau komerciniams bankams tikslinga jas interpretuoti kaip bendrą rinką, kurioje bankai veikia kaip vienas iš jos dalyvių, siekiantis didesnès apyvartos. Kadangi šiuo metu Lietuvos komercinių bankų apyvarta sudaro tik 1-2 \% suminių namų ūkių vartojimo piniginiu srautų, t. y. santykinai 3-5 kartus mažiau nei pažangių ekonomikų šalyse, bankams derètų aktyviai veikti procesus šiose rinkose, ypač skatinant racionalų vartojimą. Aktyvus veikimas šiose rinkose, naudojant adekvačius išteklius ir priemones, efektyvumo prasme prilygstančias toms, kurias taiko prekių ir paslaugų pardavejai, turètų tapti vienu iš pagrindinių strateginių bankų siekių.

2. Namų ūkio finansinių išteklių valdymo kokybe elementariųjų pirkinių lygiu gali būti pagerinta diegiant formalizuotas sprendimų prièmimo procedūras, ribojančias ekonomiškai nepagrịstų, psichologinio pobūdžio motyvų įtaką finansinių išteklių paskirstymui tarp ịvairių poreikių. Sprendimų prièmimo formalizavimo problemai spręsti gali būti panaudotas pirkinių suminès vertès vektorinis skaidymas ị atskiras komponentes remiantis Maslow poreikių teorija, suteikiant šioms komponentems kiekybinius įverčius.

3. Suminiu šalies mastu vartojimo piniginių srautų valdymo efektyvumas gali būti pagerintas modifikuoto neformalaus bendradarbiavimo tarp komercinių bankų ir namų ūkių pagrindu suformavus specifinę ekonominio, finansinio ir psichologinio banko klientu švietimo sistemą, orientuotą $\mathfrak{i}$ jų racionalios finansinès ir vartojimo elgsenos ugdymą.

4. Darbe siūloma vartojimo piniginių srautų valdymo sistema, aprépianti elementariųjų pirkinių ir suminių piniginių srautų šalies mastu lygius, 
gali būti naudojama kaip komercinių bankų pelno generavimo ịrankis. Investicijų atsipirkimą i šios sistemos suformavimą ir veiklos palaikymą laiduoja mažèjantys nuostoliai dèl neveiksnių paskolų ir augančios bankinių paslaugų pardavimo apimtys.

\section{Darbo rezultaty aprobavimas}

Disertacijos tema yra atspausdinti 7 moksliniai straipsniai: vienas - mokslinès informacijos instituto duomenų bazės „ISI Web of Science“ leidinyje, turinčiame citavimo rodiklị (Taujanskaite et al. 2015); vienas - mokslinès informacijos instituto duomenų bazès „ISI Proceedings“ leidinyje (Taujanskaitè, Milčius 2012), trys - kitu tartautinių duomenų bazių leidiniuose (Taujanskaitė, Jurevičienė 2010; Taujanskaité, Milčius 2014; Jurevičienè, Taujanskaitè, Sukačevskytė 2016), du - kituose recenzuojamuose mokslo leidiniuose (Taujanskaitė 2011, Taujanskaitė, Milčius 2015). Disertacijos tema perskaityti 7 pranešimai Lietuvos bei tarptautinèse konferencijose.

- 13-oji Lietuvos jaunuju mokslininku konferencija „VERSLAS XXI AMŽIUJE“, pranešimas lietuvių kalba: „Asmeninių finansų valdymo ypatumai ekonominio nestabilumo sąlygomis“.

- 1-oji tarptautinè mokslinė konferencija 'Practice and Research In Private And Public Sector'2011”, pranešimas anglų kalba'The Changes in Household Financial Behaviour During Economic Crisis in Lithuania'.

- 7-oji tarptautinè mokslinè konferencija 'Business and Management'2012', pranešimas anglų kalba 'Impact of Financial Crisis on Lithuanian Households's ability to manage their Budgets'.

- 2-oji tarptautinè mokslinè konferencija 'Contemporary Issues in Business, Management and Education'2013', pranešimas anglụ kalba 'Development and Sustainability Risks of Lithuanian Consumer Credit Market'.

- 15-oji tarptautinè mokslinė konferencija 'Perspectives of Business and Entrepreneurship Development', pranešimas anglų kalba 'Integrated Cross Disciplinary Approach to Household Expenditure Management'.

- 1-oji tartautinè mokslinè konferencija '1st International Conference on Business Management', pranešimas anglų kalba 'Management of Household Expenditure by Using Value Decomposition Technique'.

- 4-oji tarptautinė mokslinè konferencija 'Contemporary Issues in Business, Management and Education'2015', pranešimas anglų kalba 'Consumer Behaviour of Bank Clients: Patterns and Influence on Performance of Commercial Banks'.

\section{Disertacijos struktūra}

Disertaciją sudaro įvadas, trys skyriai ir bendrosios išvados. Taip pat yra 10 priedų.

Darbo apimtis yra 135 puslapiai, neskaitant priedų, tekste panaudotos 36 numeruotos formulès, 33 paveikslai ir 9 lentelès. Rašant disertaciją buvo panaudota 259 literatūros šaltinių. 


\section{Namų ūkiụ piniginiai srautai prekių, paslaugụ ir finansụ rinkose: valdymo problemos namų ūkiụ ir mažmeninės bankininkystès požiūriu}

Darbe ištirti ir tarpusavyje palyginti namų ūkių piniginiai srautai prekių, paslaugų ir finansų rinkose. S1 lentelè rodo, kad namų ūkių vartojimo išlaidos sudaro apie 2/3 Lietuvos BVP. Jų apimtys apie 3 kartus viršija bendraji Lietuvos biudžetą ir apie 4,5 karto Valstybinès mokesčių inspekcijos ị biudžetą surenkamų mokesčių sumą. Vien dėl to jų reikšmė yra ypatinga tiek visos šalies ekonominei sistemai, tiek atskirai paimtam kiekvienam jos subjektui, nepriklausomai nuo veiklos pobūdžio ar segmento, kuriame jis veikia: gamybos, paslaugu, iskaitant ir finansines.

S1 lentelè. Namų ūkių vartojimo išlaidų dinamika ir svarba šalies ekonomikai (sudaryta autorès, remiantis Eurostat duomenimis, 2016)

\begin{tabular}{l|c|c|c|c|c|c|c|c}
\hline \multirow{2}{*}{ Metai } & \multicolumn{7}{|c}{ Mln. EUR (einamosiomis kainomis) } \\
\cline { 2 - 10 } & 2008 & 2009 & 2010 & 2011 & 2012 & 2013 & 2014 & 2015 \\
\hline Realusis BVP & 32696 & 26935 & 28028 & 31263 & 33335 & 34962 & 36444 & 37190 \\
\hline $\begin{array}{l}\text { Namų ùkių } \\
\text { vartojimo } \\
\text { išlaidos }\end{array}$ & 20858 & 18076 & 17892 & 19658 & 20950 & 21968 & 22854 & 23997 \\
\hline $\begin{array}{l}\text { Procentai nuo } \\
\text { BVP, \% }\end{array}$ & 64 & 67 & 64 & 63 & 63 & 63 & 63 & 65 \\
\hline
\end{tabular}

S2 paveiksle pateikti duomenys rodo, kad Lietuvos komercinių bankų pajamos sudaro apie 0,6 mlrd. EUR per metus (2014 m.), iš kurių beveik puse (0,3 mlrd. EUR) yra susiję su namų ūkiais. Kadangi namų ūkiai vartojimui išleidžia apie 22 mlrd. EUR, finansų rinkoms tenka tik apie $1-2 \%$ šios sumos.

Piniginių srautų prasme prekių ir paslaugų rinka visiškai dominuoja, kas reiškia, jog bankų ịsitraukimas ị namų ūkių gerovès formavimą yra santykinai menkas.

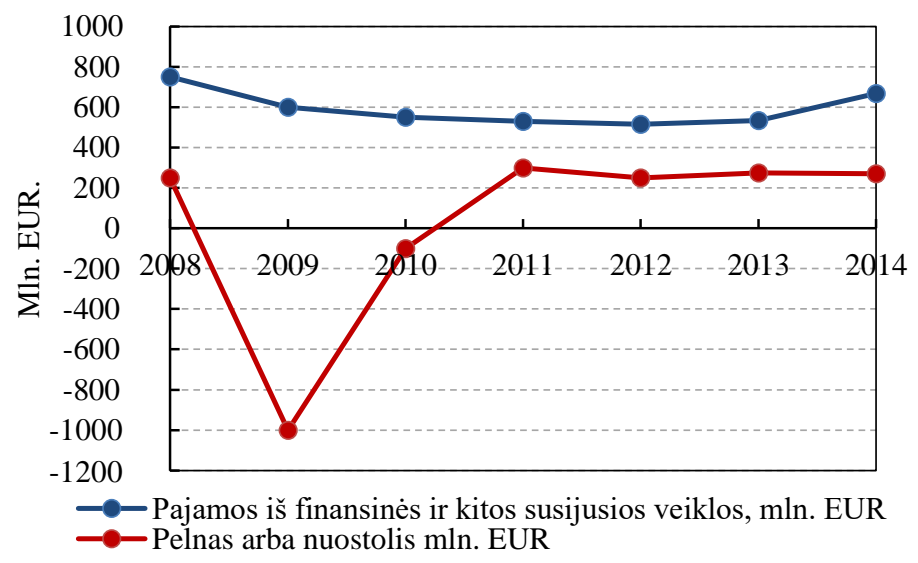

S2 pav. Komercinių bankų pajamų ir pelno dinamika Lietuvoje, mln. EUR (sudaryta autorès, remiantis Lietuvos banko ir Lietuvos bankų asociacijos duomenimis, 2015) 
Pastarosios 2008-2010 m. finansų krizès laikotarpiu autorès pakartotinai atlikti keli namų ūkių biudžetų subalansavimo tyrimai (S3 pav.) atskleide, jog krizè neigiamai paveikè tik aukštas pajamas turinčiu namų ūkių biudžetus, o namų ūkiai, kurių pajamos vidutinès ir mažos, nuo jos beveik nenukentëjo arba, priešingai, poveikis buvo netgi teigiamas. Šie rezultatai gana neblogai koreliuoja su kitose šalyse atliktais tyrimais ir leidžia teigti, jog pajamų lygis nẻra svarbiausias namų ūkių biudžetų būklę lemiantis veiksnys.

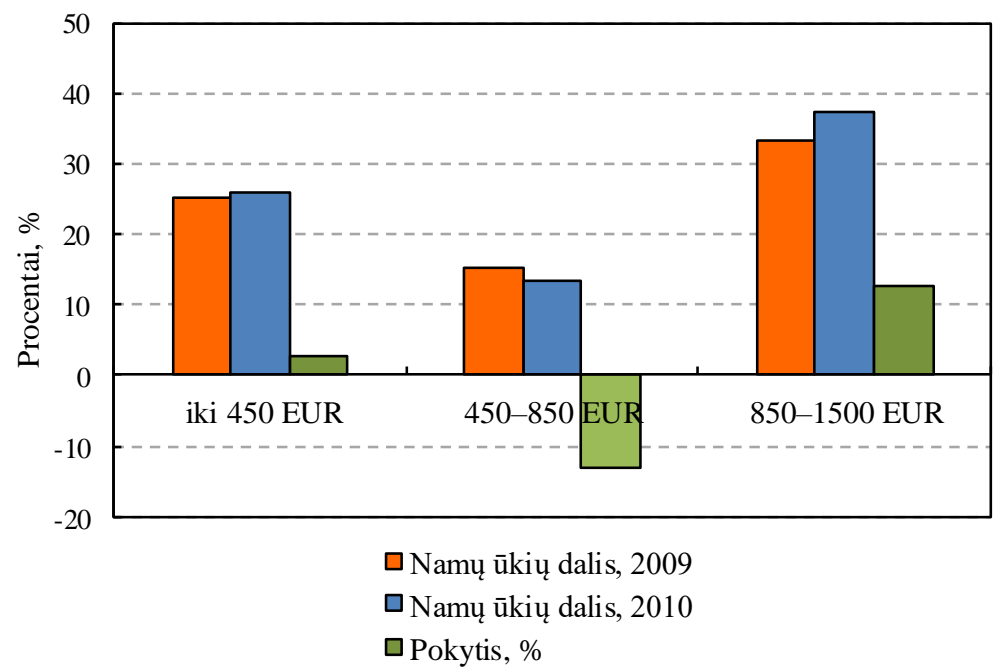

S3 pav. Namų ūkių biudžetų subalansavimo tyrimų rezultatų suvestinė (sudaryta autorès)

Atlikta mokslinių šaltinių istorinè analizè parodè, kad didžioji dalis mokslinių tyrimų, susijusių su namų ūkių vartojimo finansiniais srautais ir jų valdymu, buvo vykdomi juos vertinant iš makroekonomikos pozicijų. Moksliniu tyrimų mikroekonomikos, t. y. pačių namų ūkių gaunamos naudos požiūriu, apimtys lyginant su makroekonominiu yra daug mažesnès, didžioji jų dalis buvo atlikta iki XX a. vidurio ir neįvertina naujausių tendencijų vartojimo rinkose.

Išanalizuotos teorijos dažniausiai tiria su namų ūkių vartojimu susijusius globalius procesus rinkose, jų priežastis ir pasekmes, tačiau paprastai ignoruoja aktualius sprendimų prièmimui elementariujų pirkinių lygiu procesus, kurie galiausiai ir suformuoja darbe analizuojamus finansinius srautus. Tokių pirkimų vartotojas per dieną atlieka $n$ kartų ir kiekvienas iš jų turi $m$ alternatyvų. Žinomi klasikiniai su namų ūkių vartojimu susiję uždaviniai siūlo optimalius sprendimus tik ieškant santykio tarp einamojo ir ateities vartojimo arba kai einamojo vartojimo alternatyvų skaičius neviršija dviejų. Tik šie uždaviniai turi klasikinius sprendinius, tačiau jie negali būti pritaikyti kasdieniams $n \times r m$ pirkimams valdyti dèl didelio alternatyvų skaičiaus. Kadangi kiekvienos iš šių alternatyvų kainos gali skirtis nuo kelių iki kelių tūkstančių kartų, nesant formalių sprendimu prièmimo procedūrų, intuityviai priimami pirkimo sprendimai negarantuoja racionalaus finansinių išteklių panaudojimo, todèl namų ūkiai susiduria su biudžetu valdymo problemomis bei sunkumais vykdant prisiimtus finansinius ịsipareigojimus kredito institucijoms. 


\section{Formalizuoto namų ūkio vartojimo išlaidų valdymo principai ir ju praktinis taikymas}

Rinkoje veikiantys prekių ir paslaugų pardavejjai, siekdami skatinti pardavimus, plačiai taiko ịvairias rinkodaros priemones ir stengiasi išnaudoti psichologinio poveikio vartotojui galimybes. Darbe atlikta ekonominių teorijų ir praktiniam naudojimui skirtų finansų valdymo priemonių analizė atskleidé, kad jos nėra pritaikytos apsaugoti vartotoją nuo neigiamo tokių veiksnių poveikio. Šio skyriaus tikslas - pasiūlyti galimą šios problemos sprendimą. Pateiktieji formalizuoto einamojo vartojimo išlaidų valdymo principai yra pagrịsti formalių, kiekybiniais kriterijais grindžiamų procedūrų taikymu ir buvo suformuoti integruojant tiek ekonominį, tiek psichologini požiūrị i vartojimo sprendimų prièmimą.

Šie principai remiasi prekių ir paslaugų vertès dekompozijos idejja, leidžiančia bet kurios prekès ar paslaugos suminę vertę išskaidyti ị atskiras vertès komponentes, kurios atitinka Maslow poreikių piramidès lygius, ir nustatyti kiekybinius šių komponenčių įverčius, išreiškiančius jų svorị bendrojoje vertès (kainos) struktūroje.

Atskyrus ir kiekybiškai įvertinus vertès komponentes, atsiranda galimybè nuspręsti, kaip, vertinant pagal Maslow poreikių teoriją, jos atitinka vartotojo poreikius, ir ar perkant konkrečią prekę / paslaugą bus racionaliai panaudoti finansiniai asmens ištekliai.

Supaprastinta skaidymo $i \mathfrak{\text { tris }}$ poreikių lygius grafine interpretacija pateikta S4 paveiksle.

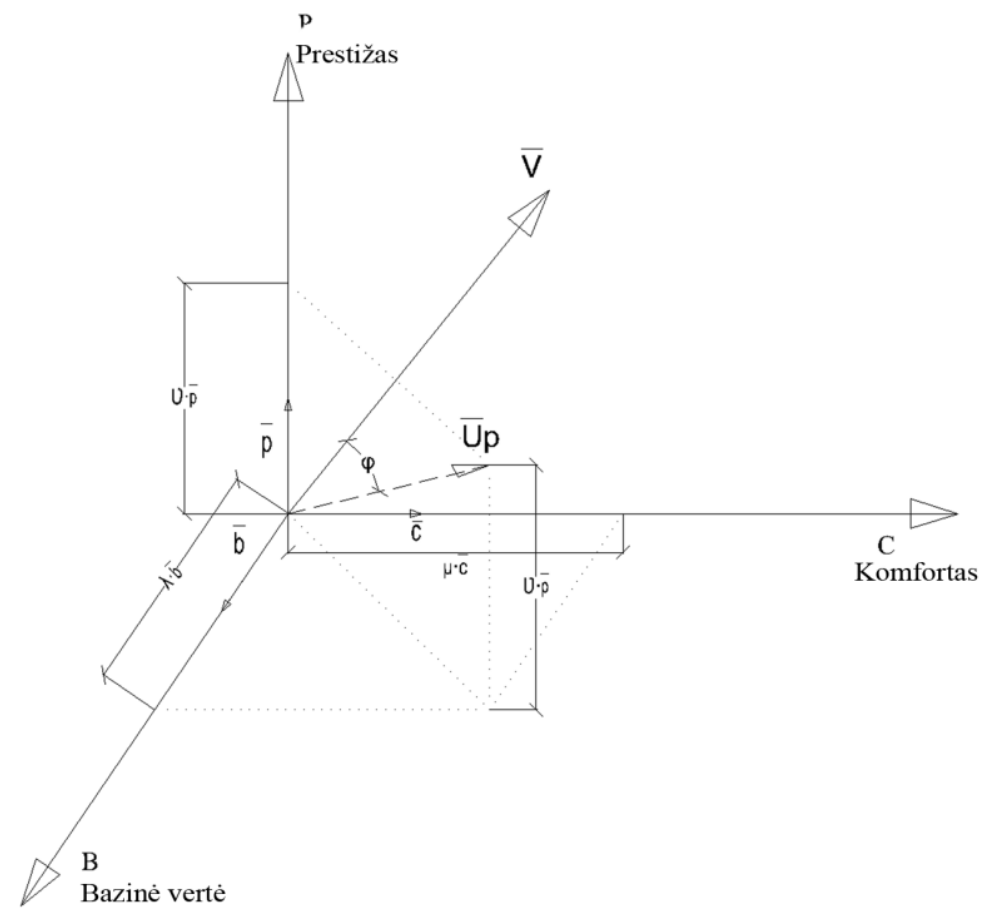

S4 pav. Vertès dekompozicijos grafinè interpretacija (sudaryta autorès) 
Vertès dekompozicijos principo praktinis pritaikymas

Naudojantis vienu iš žinomų biudžeto sudarymo metodų, suformuojamas planuojamo laikotarpio poreikių sąrašas (matrica), kuriame detaliai ịvardijami šio laikotarpio pirkiniai:

$$
N=\left[\begin{array}{ccc}
n_{11} & \cdots & n_{i 1} \\
\vdots & \ddots & \vdots \\
n_{1 j} & \cdots & n_{i j}
\end{array}\right]
$$

čia $N$ - planuojamo laikotarpio pirkinių matrica, $n_{i j}$ - poreikio kategorijos , $i “$ poreikis,$j$ “", kai $i$ kinta ribose $1 \leq i \leq s$, o $j$ ribose $1 \leq j \leq t$.

Jos pagrindu ir remiantis planuojamų pirkinių bazinių verčių kainomis suformuojama poreikių bazinių kainų matrica $N_{B}$ :

$$
N_{B}=\left[\begin{array}{ccc}
n_{11} * \lambda_{11} & \cdots & n_{i 1} * \lambda_{i, 1} \\
\vdots & \ddots & \vdots \\
n_{1 j} * \lambda_{1, j} & \cdots & n_{i j} * \lambda_{i, j}
\end{array}\right],
$$

čia $\lambda_{i, j}$ yra $i, j$ poreikio bazinę vertę atitinkanti kaina.

Toliau apskaičiuojamas laikotarpio bazinis biudžetas:

$$
B_{b}=\sum_{\substack{1 \leq i \leq s \\ 1 \leq j \leq t}}^{s, t} n_{i, j} * \lambda_{i, j} .
$$

Šio biudžeto reikšmè tapati individualiam pragyvenimo minimumui, t. y. jis nurodo, už kiek namų ūkis galètų pragyventi, jei vartotų orientuodamasis tik ị bazines produktų bei paslaugų vertes ir atitinkamas kainas. Tai valstybès skelbiamo pragyvenimo minimumo analogas, tik individualizuotas projektuojant i konkretaus individo bazinius poreikius.

Naudojantis vienu iš žinomų biudžeto planavimo metodų, pavyzdžiui, iALM tipo (Dempster, Medova 2011), laikotarpio planuojamos gauti pajamos paskirstomos einamajam vartojimui ir kaupimui, skirtam sukaupti atsargas būsimiesiems laikotarpiams.

Randamas einamojo laikotarpio biudžeto apimčių santykis su baziniu biudžetu ir tokiu būdu apskaičiuojamas,$I_{v}{ }^{“}$, t. y. individualus vartojimo indeksas.

$$
I_{v}=\frac{B_{c}}{B_{b}} .
$$

Dauginant poreikių matricos elementus iš individualaus vartojimo indekso $I_{v}$, suformuojama vartotojo preferencijų matrica, nurodanti kiekvieno pirkinio preferencinę kainą. Naudodamas šią informaciją vartotojas gali laisvai rinktis bet kurị pirkinị, kurio kaina neviršija preferencinès kainos. İsigyjant pirkinį už mažesnę ar didesnę nei preferencinė kaina, nuokrypis nuo preferencinès kainos formuoja preferencinio biudžeto pervirši arba deficitą. Darbe sukurtos taikomosios programos tokius nuokrypius registruoja automatiškai. Programos pateiktos $\mathrm{C}$ priede. 
Preferencijų matrica iš esmès atitinka Pareto alokacinio efektyvumo (optimumo) principus, kadangi kiekvieno planuojamo pirkinio vertès ir atitinkamos kainos struktūra yra sudarytata taip, kad bazinès ir kitų suminès vertès komponenčių santykis yra išlaikomas vienodas visų prekių ir paslaugų aibèje nepriklausomai nuo jų paskirties. Pagal šiuos principus visi namų ūkio vartojimo poreikiai tenkinami neviršijant numatyto einamojo vartojimo biudžeto $B_{c}$. Prekių ir paslaugų bazinių verčių nustatymas vykdomas tos pačios paskirties prekių aibejje suradus minimalios kainos alternatyvą ir ją prilyginus bazinei vertei, turinčiai kainos dimensiją. Skyriuje atlikta analizė leido nustatyti kai kurių produktų bazinių ir suminių verčiu santykị. Šis santykis daugeliu atveju siekia nuo kelių kartų iki kelių tūkstančių kartų, pavyzdžiui, tai būdinga netgi tokiam ịprastam produktui, kaip geriamasis vanduo. Verčiu santykis ir jo analizè gali tapti svarbiu racionalaus namų ūkio finansinių išteklių valdymo veiksniu, kuris kol kas praktiškai nėra panaudojamas.

\section{Vartojimo finansiniu srautu valdymo sistemos formavimas modifikuoto namų ūkiụ ir komercinių bankų bendradarbiavimo pagrindu}

Ši darbo dalis skirta paieškai sprendimų, kuriais remiantis būtų galima efektyviau nei šiuo metu, valdyti namų ūkių vartojimo piniginius srautus, pagerinti namų ūkių biudžetų būklę, ju gebejjimą geriau vykdyti ịsipareigojimus kredito ịstaigoms. Pradiniame etape buvo identifikuoti veiksniai, turintys įtakos banko klientų nemokumui. Pasiūlyta šių veiksnių klasifikavimo schema, skirstant juos ị tiesioginius ir netiesioginius (S5 pav.), atliktas jų itakos vertinimas.

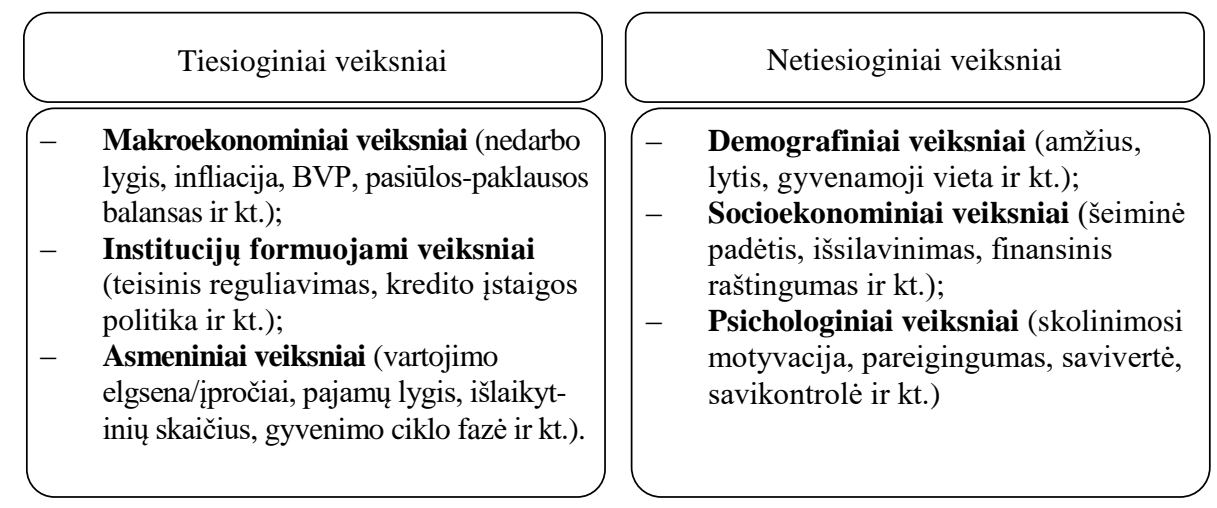

S5 pav. Tiesioginiai ir netiesioginiai veiksniai, lemaintys asmens mokumą (sudaryta autorès, remiantis Jurevičienè et al. 2016)

Analizuojamų veiksnių kiekybiniam vertinimui buvo atliktas specialus tyrimas naudojant ekspertinio vertinimo metodiką ir pasitelkiant 24 patyrusius bankų specialistus. Tyrimu nustatyta, kad kliento nemokumą labiausiai lemia jo vartojimo 
elgsena $(30,5 \%)$ ir finansinių žinių trūkumas (30,2 \%). Susisteminti atlikto ekspertinio tyrimo rezultatai pavaizduoti S6 paveiksle.

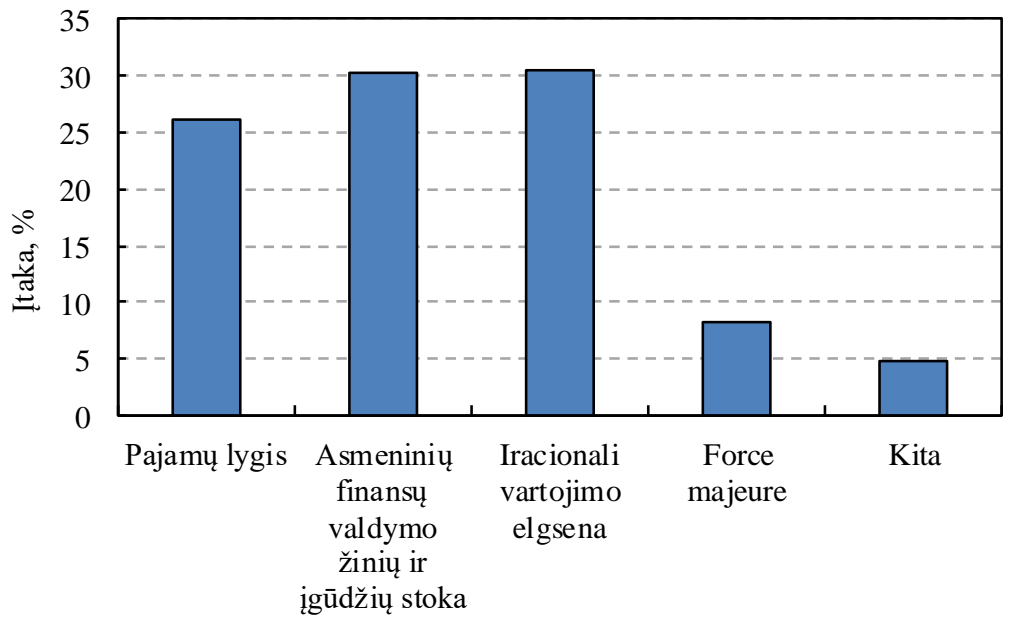

Nemokumą lemiantys veiksniai

S6 pav. Privačių banko klientų nemokumo priežastys (sudaryta autorès)

Abu šie veiksniai kartu lemia apie $60 \%$ neveiksniu paskolų apimčių mažmeninèje bankininkystèje ir kiekvienas iš jų gali būti veikiamas specialiomis švietimo priemonèmis, todèl šiame skyriuje keliama idejja plètoti neformalu komercinių bankų ir namų ūkių bendradarbiavimą, orientuotą į finansų ir vartojimo valdymo gerinimą namų ūkiuose. Tokiam bendradarbiavimui palanku tai, kad šiuo atveju tiek bankų, tiek namų ūkių interesai artimai sutampa ir jie natūraliai siekia panašių tikslų, o bankų ištekliai galètų prisidèti prie jų igyvendinimo. Išanalizavus dabartinį namų ūkių ir komercinių bankų bendradarbiavimą, buvo identifikuoti esminiai trūkumai, kylantys iš to, jog ir bankai, ir namų ūkiai savo problemas sprendžia atskirai - neišnaudoja glaudesnio bendradarbiavimo galimybių. Bankams būtų tikslinga neapsiriboti dabartiniu formaliu bendradarbiavimu su klientais remiantis komercinemis sutartimis, o ji modifikuoti, grindžiant nauju požiūriu ị klientą, kaip pagrindinị šalies finansinių srautų šaltinị bei įtraukiant ị bendradarbiavimą specialų finansinį-ekonominị ir ypač psichologinị klientų švietimą.

Tikètina, kad šių priemonių taikymas galètų sumažinti bankų nuostolius tokiu pat mastu, kokiu neefektyvus finansų ir vartojimo valdymas lemia neveiksnių paskolų lygị, t. y. iki $60 \%$. Savo ruožtu šių priemoniu igyvendinimas, jei jị finansuotu bankai, būtų susijęs su papildomais kaštais, kuriuos, tikimasi, kompensuos sumažèję nuostoliai. Skyriuje atliktas tokių priemonių panaudojimo ekonominio atsiperkamumo tyrimas grindžiamas lygčių sistemos analize: 


$$
\left\{\begin{array}{l}
L_{B L}-\text { const } \\
E(h)=C_{E} * h \\
G(h)=k * L_{B L} * \ln (h) * \frac{1}{\ln \left(h_{\max }\right)}
\end{array},\right.
$$

čia $L_{B L}$ - komercinių bankų nuostolių lygis dèl neveiksnių paskolų, išduotų privatiems klientams iki poveikio priemonių taikymo; $E(h)$ - kaštai, susiję su klientų finansiniuekonominiu ir psichologiniu švietimu, EUR; $h-\left\{0 \div \mathrm{h}_{\max }\right\}$ švietimo kursų trukmè, val.; Bendra vienos švietimo valandos kaina šalies mastu $C_{E}=C_{c l} * W / n_{c l}$, čia $C_{c l}-$ švietimo kursų valandos, tenkančios vienai klausytojų grupei, kaina; $W$ - bendras klausytojų skaičius šalies mastu; $n_{c l}$ - klausytojų skaičius grupejje; $G(h)$ - grąža, gaunama iš investavimo ị švietimo sistemą; $k-\{0 \div 1\}$ koeficientas, išreiškiantis nuostolių dèl blogų paskolų dalị, kuri gali būti valdoma švietimo priemonėmis; $\ln (h)$ - koeficientas, išreiškiantis žinių įsisavinimo spartos priklausomybę nuo kursų trukmès; $\ln \left(h_{\max }\right)-$ konstanta, naudojama suteikti žinių ịsisavinimo koeficientui santykinių vienetų formatą.

Bendra nuostolių dẻ neveiksnių paskolų ir investicijų ị klientų švietimą suma:

$$
L_{\Sigma}=L_{B L}+E(h)-G(h)=L_{B L}+C_{E} * h-k * L_{B L} * \ln (h) * \frac{1}{\ln \left(\mathrm{m}_{\max }\right)} .
$$

Suminių nuostolių $L_{\Sigma}$ vertès, esant ịvairioms $L_{B \mathrm{~L}}$ reikšmèms $(10,20,30 \mathrm{ir}$ $40 \mathrm{mln}$ EUR), kai $C_{c l}=60$ EUR, $n_{c l}-30, W-50000$ ir $k=0,7$, apskaičiuotos kaip švietimo kursų trukmès $h$ funkcija, pateiktos S7 pav., o S8 pav. šias vertes pateikia kaip investicijų i švietimo sistemą dydžio funkciją.

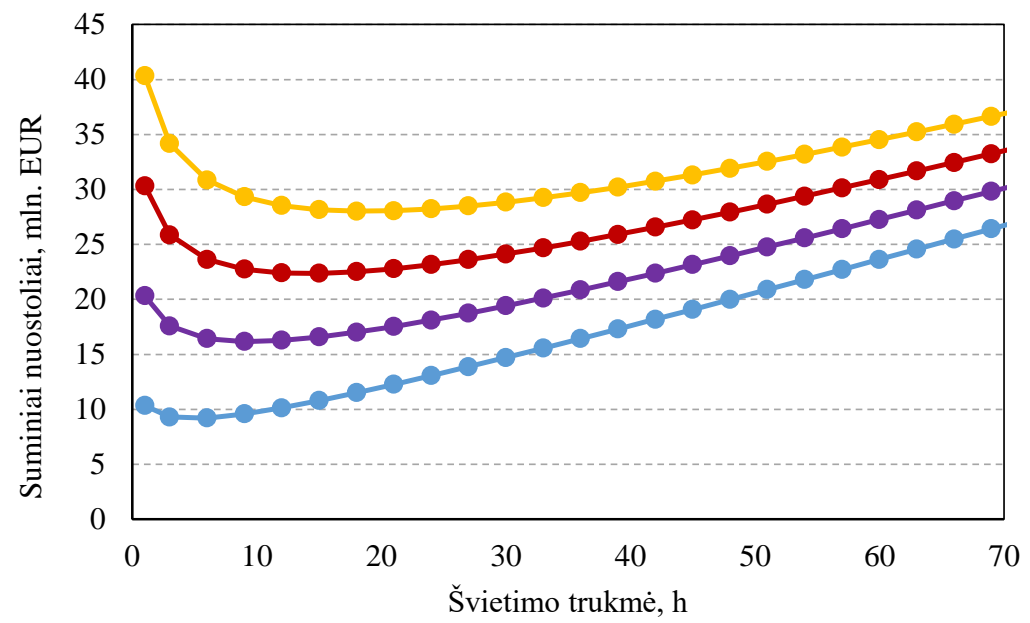

\begin{tabular}{l}
$\longrightarrow$ \\
$\longrightarrow-30 \mathrm{mln}$. EUR \\
$-20 \mathrm{mln}$. EUR \\
\hdashline$-40 \mathrm{mln}$. EUR
\end{tabular}

S7 pav. Banko klientų švietimo poveikis suminiams bankų nuostoliams dèl neveiksnių paskolų (sudaryta autorès) 


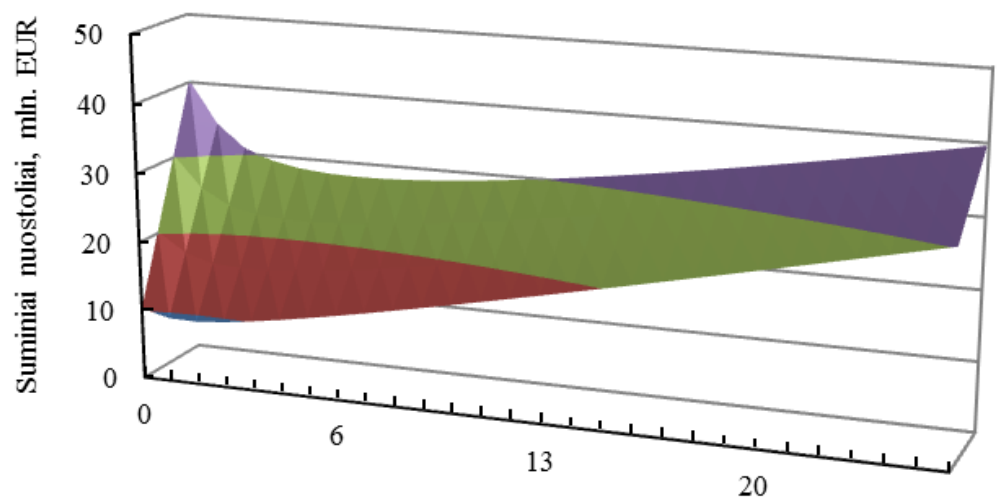

Investicijos ị švietimą, mln. EUR

S8 pav. Prognozuojama komercinių bankų suminių nuostolių dẻl neveiksnių paskolų priklausomybė nuo investicijų ị klientų švietimą dydžio (sudaryta autorès)

Kadangi funkcijos, išreiškiančios suminius nuostolius po investavimo i švietimą turi aiškiai išreikštus ekstremumus, iš jų galima parinkti tinkamą mokymo kursų trukmę ir atitinkamą investicijų dydị. Tuo tikslu randama fukcijos $L_{\Sigma}$ išvestinè, kurią prilyginus nuliui, paskaičiuojama reikiama švietimo kursų trukmè $h$ ir investicijų dydis $E$ :

$$
\begin{gathered}
\frac{\partial L_{\Sigma}}{\partial h}=\frac{\partial L_{B L}}{\partial h}+\frac{\partial\left(C_{E} * h\right)}{\partial h}-\frac{\partial\left(k * L_{B L} * \frac{\ln (h)}{\ln \left(h_{\max }\right)}\right)}{\partial h}=0, \\
h=\frac{k * L_{B L} * n_{C l}}{C_{C l} * W * \ln \left(h_{\max }\right)}, \\
E=\frac{k * L_{B L}}{\ln \left(h_{\text {max }}\right)} .
\end{gathered}
$$

Atidejinių rizikingoms paskoloms lygis Rytų ir Vakarų Europos komerciniuose bankuose 2007-2014 metų laikotarpiu svyravo 10-23\% ribose, kas rodo, jog ši problema aktuali ne tik Lietuvos, bet ir kitų šalių komerciniams bankams. Didelès atidejjinių apimtys rodo esant galimybių restruktūrizuoti bankų išteklius ir dalị jų nukreipti ị klientų finansinès ir vartojimo elgsenos tobulinimo priemones, traktuojant tai kaip prevencinius veiksmus, kurie mažina nepageidaujamas neveiksnių paskolų pasekmes.

Investicijų i banko klientų finansinès ir vartojimo elgsenos tobulinimą atsiperkamumo prognozė (S8 pav.) leidžia teigti, jog bankams būtų ekonomiškai naudinga suformuoti atitinkamą klientų švietimo infrastruktūrą, integruojant i ją antrame darbo skyriuje pasiūlytus formalizuoto elementariųų pirkinių valdymo principus, metodus bei praktiniam naudojimui skirtas priemones. Toks darinys sukurtų vieningą namų ūkių vartojimo piniginių srautų formalizuoto valdymo sistemą, leidžiančią juos valdyti tiek elementariujų pirkinių, tiek ir suminių šalies mastu vartojimo piniginių srautų lygiu. Suminių piniginių srautų, kitaip nei elementariųų pirkinių lygiu, valdymas nėra tiesioginis, jis realizuojamas per įtaką komercinių bankų klientų gebejjimams finansų ir 
vartojimo valdymo srityse. Ši sistema grafiškai pavaizduota S9 paveiksle. Ji grindžiama modifikuotu namų ūkių ir komercinių bankų bendradarbiavimu, igyvendinamu pastarujų iniciatyva ir remiantis jų finansiniais ištekliais. Komercinių bankų motyvas investuoti $\mathfrak{i}$ tokios sistemos kūrimą remiasi didele atsipirkimo tikimybe, pagrịsta šiame skyriuje pateikiamais tyrimų rezultatais.

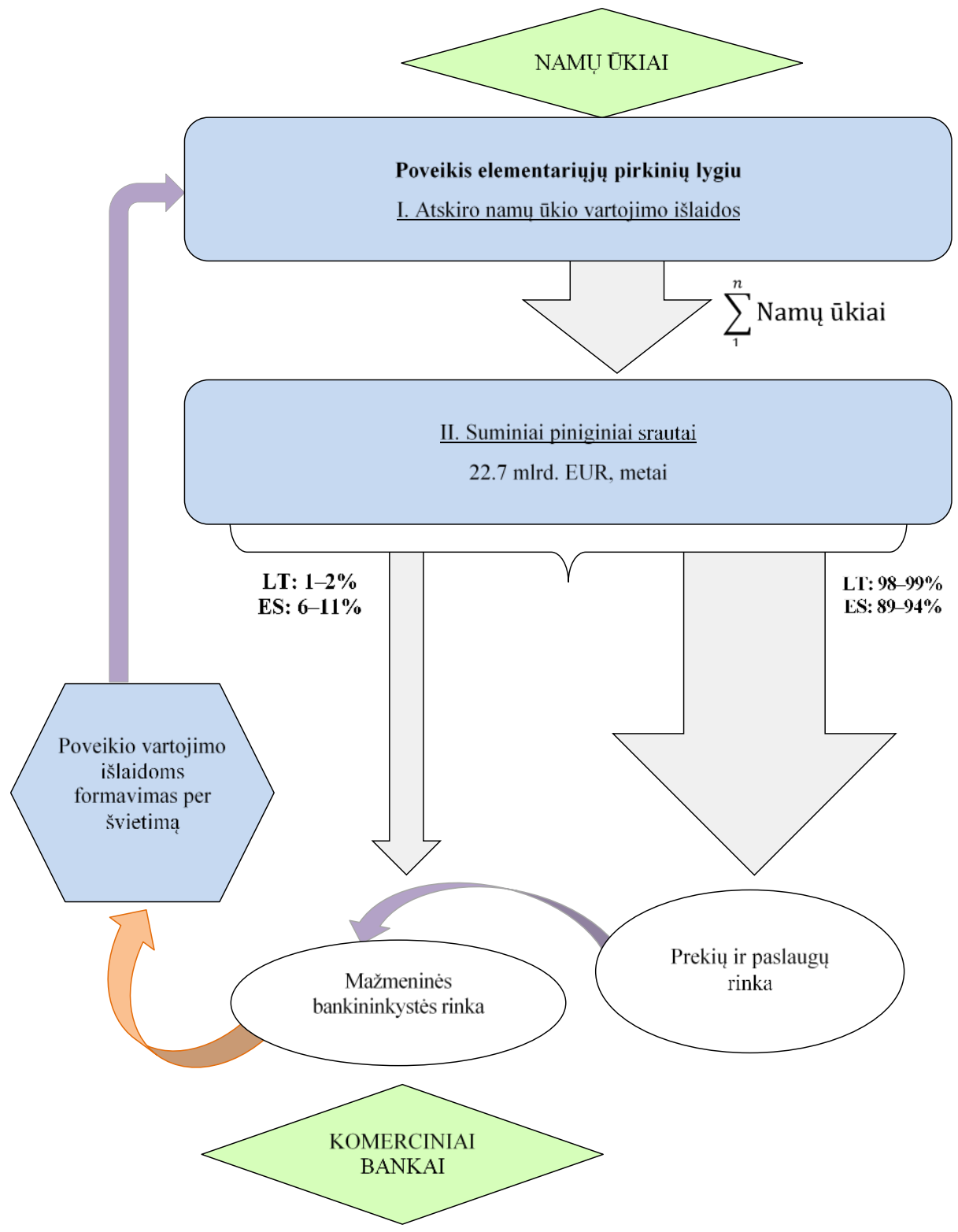

S9 pav. Sistemos modelis (sudaryta autorès) 
Skyriuje pasiūlytas investiciju atsipirkimo ịvertinimo metodas bei analitinès švietimo sistemos kursų trukmès ir investicijų dydžio prognozavimo formulès, pagrindžia galimybę sumažinti komercinių bankų patiriamus praradimus dèl neveiksnių paskolų modifikuojant dabartinị bendradarbiavimo su namų ūkiais pobūdị. Be to, tikètinas teigiamas siūlomos sistemos poveikis mažmeninès bankininkystės apyvartai, kuri šiuo metu Lietuvoje yra nepagrịstai maža (net 3-5 kartus mažesnè nei daugelyje kitų ES valstybių). Prognozuojamas šių abiejų veiksnių poveikis komercinių bankų ekonominès veiklos rezultatams savo apimtimis pralenkia investiciju poreiki sistemos sukūrimui ir jos veiklos finansavimui.

\section{Išvados}

1. Namų ūkių vartojimo išlaidos Lietuvoje sudaro apie $2 / 3$ šalies BVP, taigi efektyvus šių srautų valdymas yra labai svarbus šalies ekonomikai makro- ir mikroekonominiu lygiu. Namų ūkių piniginių srautų pasiskirstymo tarp prekių, paslaugų ir mažmeninès bankininkystès rinkų analizè parodè, kad komercinių bankų pajamos sudaro tik apie 1-2\% nuo prekių ir paslaugų rinkos apyvartos, o 98$99 \%$ analizuojamų piniginiu srautų panaudojami prekèms ir nefinansinėms paslaugoms pirkti, kas rodo akivaizdų šio rinkos segmento dominavimą.

2. Namų ūkių piniginių srautų valdymo efektyvumas lemia pačių namų ūkių biudžetų valdymo kokybę ir su jais bendradarbiaujančių komercinių bankų veiklos rezultatus. Ištyrus Lietuvos namų ūkių finansų valdymo būklę paaiškejjo, kad reikšmingai jų daliai (30-40 \%) nepriklausomai nuo pajamų lygio nepavyksta išvengti biudžeto deficito, kas rodo rimtas namų ūkių finansų valdymo problemas. Tai tiesiogiai veikia ir privatiems asmenims išduotų neveiksnių paskolų lygi. Lietuvoje 2010 metais šis rodiklis pasieke piką, skirtingais duomenimis, sudare nuo $20 \%$ iki $25 \%$ ir lemè itin didelius komercinių bankų nuostolius (apie 1 mlrd. EUR). Komerciniams bankams prireikè net penkerių metų pelno (2010-2015 m.), kad šie nuostoliai būtų padengti. Panašios problemos būdingos ir kitų šalių, pvz., Kipro, Graikijos, Ispanijos, Italijos, Portugalijos, Airijos namų ūkiams, nors vertinant pagal statistikos rodiklius jie yra daug labiau pasiturintys už Lietuvos namų ūkius.

3. Atliktų tyrimų rezultatai leidžia teigti, kad namų ūkių biudžetų subalansavimas menkai arba apskritai nekoreliuoja su namų ūkio pajamų lygiu. Priežastys, lemiančios finansų valdymo efektyvumą, yra dvejopos. Viena vertus, jos priklauso nuo individo asmeninių savybių, gebejjimo racionaliai elgtis prekių ir paslaugu rinkoje, gebejjimo atsispirti subjektyviems psichologinio pobūdžio veiksniams, kita vertus, labai didelę reikšmę turi ir nepakankamas šių problemų ištyrimas teoriniu lygiu. Ekonominès teorijos nepateikia atsakymų i daugelị aktualių klausimų ir nepasiūlo racionalios elgsenos būdų ar 
metodų. Mokslinių šaltinių asmeninio vartojimo klausimais analizè atskleidè, jog vertinant šiuo požiūriu, ekonomikos moksle neabejotinai esama spragų. Beveik neskiriama dèmesio racionaliam kasdienio vartojimo išlaidų valdymui, nors būtent šis elementas lemia suminius vartojimo piniginius srautus, sudarančius apie $60 \%$ šalies bendrojo vidaus produkto.

4. Nei ekonominès ar psichologijos teorijos atskirai, nei šiuolaikinès integruotos teorijos nepadeda namų ūkiams susidoroti su iššūkiais, kylančiais dinamiškoje ir nuolat kintančioje ekonominejje aplinkoje. Kasdienio vartojimo sprendimai vis dar yra priklausomi nuo subjektyvios vartotojo nuomonès ir patirties, nèra formalizuotu procedūrų, kurios leistų eliminuoti jų poveikį, tad esamos biudžeto subalansavimo problemos yra natūrali šių trūkumų pasekmè. Esamą vartojimui skirtų finansinių išteklių valdymo būklę geriausiai apibūdina palyginimas su automobiliu, važiuojančiu trasa su daug greitị ribojančių ženklų, tačiau neturinčiu greitị matuojančio įtaiso. Kitais žodžiais tariant, „namų ūkių finansiniai automobiliai realiai važinèja be spidometrų“, kas ir lemia iracionalių finansinių sprendimų vartojimo srityje gausą bei bendrą namų ūkių biudžetų būklę.

5. Siekiant iš dalies užpildyti esamas mokslinių žinių spragas nagrinèjamu klausimu, darbe sukurti ir pasiūlyti ekonomini ir psichologinị požiūrị sujungiantys formalizuoti namų ūkių vartojimo išlaidų valdymo teoriniai principai, orientuoti ì priešpirkiminị vartojimo sprendimų prièmimą. Esminis šio tarpdisciplininio požiūrio elementas yra vektorinis prekių ir paslaugų suminès vertès skaidymas ị atskiras vertės komponentes, atitinkančias tam tikrą Maslow poreikių piramidès hierarchinị lygị. Lyginant, kaip prekès vertès komponentès dera su vartotojo poreikių preferencijomis pagal Maslow poreikių teoriją, sprendžiama apie šios prekès tinkamumą būtent to konkretaus vartotojo poreikiams tenkinti. Esminis siūlomo požiūrio privalumas tas, kad jis suteikia galimybę atskiras vertès komponentes palyginti kiekybiškai.

6. Atvejų analizè mikro- ir makroekonomikos lygiu patvirtino siūlomų principų pagrịstumą ir galimybę juos naudoti kaip planavimo ịrankị valdant namų ūkių kasdienio vartojimo išlaidas. Sumažinta subjektyvių sprendimų ịtaka leidžia riboti spontaniškas išlaidas, suderinti ne tik visumini vartojimą su pajamų lygiu, bet ir kiekvieną pirkini su visais likusiais to laikotarpio pirkiniais, neviršijant biudžeto galimybių. Tokia koncepcija užkerta kelią nesubalansuotam (pertekliniam arba nepakankamam) vartojimo finansinių lèšų paskirstymui, kas išskiria ją iš kitų, paliekančių sprendimų prièmimą subjektyviai vartotojo nuožiūrai.

7. Ištyrus, kokią ịtaką individo vartojimo elgsena daro namų ūkių biudžetų subalansavimui ir prisiimtų finansinių ịsipareigojimų 
vykdymui, komerciniams bankams rekomenduojama imtis jos tobulinimo veiksmų bei apskritai keisti dabar vyraujantį požiūrị i bendradarbiavimą su namų ūkiais.

8. Atliktas ekspertinis tyrimas pasitelkiant bankų specialistus atskleidè, kad apie $60 \%$ fizinių asmenų neveiksnių paskolų gali lemti kliento asmeninès savybès (vartotojo elgsena) ir finansinių žinių lygis. Dabartinè situacija pagerètų, jei asmenys būtų specialiai ekonomiškai, finansiškai ir psichologiškai šviečiami. Tai galètų lemti didesnị klientų finansų valdymo efektyvumą bei tiesioginę naudą bankams, dèl ko pastarieji turètų būti suinteresuoti šioje veikloje aktyviai dalyvauti. Naudojant darbe sukurtą metodiką nustatyta, kad investicijų i šias priemones atsipirkimas yra labai tiketinas.

9. Remiantis tyrimų rezultatais suformuluotos rekomendacijos komerciniams bankams:

- Komerciniai bankai turètų ypatingai atsižvelgti i procesus, vykstančius prekių ir paslaugu rinkose, nes jie tiesiogiai veikia bankų veiklos rezultatus. Kadangi prekių ir paslaugų pardavejjai konkuruoja su komerciniais bankais dèl namų ūkių piniginių srautų, bankams būtų naudinga veikti išvien su namų ūkiais ir ịvairiomis priemonèmis padéti jiems racionaliau naudoti savo išteklius.

- Siūloma modifikuoti esamą komercinių bankų ir namų ūkių bendradarbiavimą, i ji integruoti banko klientų specializuotą švietimą, taip suformuojant sistemą, galinčią prisidèti prie efektyvesnio namų ūkių vartojimo piniginių srautų valdymo.

- Bankams tikslinga kurti klientų ekonominio, finansinio ir psichologinio švietimo sistemą bei investuoti i ją, tikintis realaus atsipirkimo aukštesnio finansų valdymo efektyvumo dèka.

- Banko klientų vertinimas, kai atsižvelgiama tik i jų pajamų lygi, nèra adekvatus esamoms problemoms ir iššūkiams. Siūloma atsižvelgti ne tik i pajamas, bet ir i kliento finansinių žinių lygị, o ypač ị vartojimo elgseną, kadangi būtent pastarasis veiksnys lemia iki 98 \% namų ūkių piniginių lèšų panaudojimą. 


\section{Annexes}

Annex A. Consumption decision making tree

Annex B. Models for individual's asset-liability management

Annex C. Algorithms for practical use

Annex D. Model of a system for formalized control of personal consumption expenditure

Annex E. Education program for bank clients

Annex F. Household financial management questionnaire_investigation I Annex G.Household financial management questionnaire_investigation II Annex H.Expert evaluation questionnaire_round I

Annex I. Expert evaluation questionnaire_round II

Annex J. Copies of scientific publications by the autor on the topic of the dissertation

Annex K. The co-authors' agreements to present publications for the dissertation defence

\footnotetext{
* The annexes are supplied in the enclosed compact disc.
} 
Kamilè TAUJANSKAITÉ

A SYSTEM FOR FORMALIZED
CONTROL OF PERSONAL
CONSUMPTION EXPENDITURE

Doctoral Dissertation

Social Sciences,

Economics (04S)

Kamilè TAUJANSKAITÉ

ASMENINIO VARTOJIMO

PINIGINIŲ SRAUTUৃ FORMALIZUOTO

VALDYMO SISTEMA

Daktaro disertacija

Socialiniai mokslai, ekonomika (04S)

201605 19. 12,5 sp. I. Tiražas 20 egz.

Vilniaus Gedimino technikos universiteto leidykla „Technika“,

Saulètekio al. 11, 10223 Vilnius,

http://leidykla.vgtu.It

Spausdino UAB „Ciklonas“

J. Jasinskio g. 15, 01111 Vilnius 